ability of some obstacles in intracellular hormone synthesis by the hypophysectomy, and at least the changes by ACTH was akin, beyond the recovery, to the pattern of elevation in function of cortical cells, as is seen in intact rats exposed by the stressful stimuli.

The repair test by ACTH showed the same improvement as by its maintenance test. Of course, the betterment may be restricted to zonation and cell internal structures in connection with the metabolic amelioration, but was not involved in the hyperplasia of cotical cells.

In the event of repeated injections of GH for 7 days (maintenance test) to the hypophysectomized rats, the symptom of the ablation is almost irrecoverable. The changes is not utterly reconcile with the findings of hypophysectomized untreated group, but usually provides the fascicular arrangement of zona glomerulosa whose superficial cells underlying the capsule are packed with the stainable granules, and whose profound areas contain numerous fat granules. Also GH administration alone could deprive of the connective tissue layer surrounding the medulla. Therefore it is enough to allow for us to make an assumption in the present cytological observation that the administration of $\mathrm{GH}$ alone is not always uneffective to the adrenal cortex, but engage in a certain stmulative actions.

The repeated injections of ACTH and GH in combination for 5 days (repair test) to the hypophysectomized rats made the remarkable improvement in the ablation symptom in the following respects : The hypertrophic action of zona glomerulosa was strongly inhibited; the cell-strands of zona fasciculata extend themselves to the capsule, beneath which is sometimes seen the immature glomerulum, where the consistuent cells were full of stainable granules instead of fat droplets; the deprivation of transitional zone resulted in the natural transformation of zona glomerulosa downwards up to zona fasciculata with the subsequent formation of the continuous elongated cell-strands. Despite the arrangement of fasciculata cell and the atrophic patterns were not sifficientiy recovered so much as by ACTH administration, it was a commonly characteristic to this event that the abundant stainable granules was associated with a lot of fat granules of the corresponding size within fasciculata cells, showing the excitable but stabilized pattern regarding the cellular metabolism. The combined administration may have an important links with the co-operated action to the adrenal cortex on reasons that the cell degeneration or disintergration near the medulla is most effectively sustained.

In summarized, we can furnish an information that, although the combined administration of ACTH and GH is unable to inhibit the reduction in cell number and volume, it may conduct to improve harmoniously the disfunction reflected to the cell distribution and internal structure, and rather put the cortex cells into a hyperfunctional state.

\title{
Experimental Studies on the Influence of Endocrine Functions upon the Erythrocyte Respiration
}

By

\section{Toshio MIGIHASHI}

Department of Medicine, Kyoto Pref. Univ. of Med. (Director : Prof. S. Tateishi, M.D.)

The author investigated the erythrocyte respiration in left ventricle blood of endocrine eviscerated rabbit and the effect of different hormone upon it. Oxygen consumption was measured by means of the direct Warburg's method, and coefficient of respiration was calculated.

Vol. 35 No. 12 
The results were summarized as followings.

(1) In the experimental hyperthyroidism by the thyradin injection, $\mathrm{QO}_{2}$ of erythrocyte is remarkably enhanced, but $\mathrm{QCo}_{2}$ does not show any variation.

(2) On the other hand, in the experimental hypothyroidism by bilateral thyroidectomy, the erythrocyte respiration decreases after long times. (about thirty days).

(3) By the injection of cortisone acetate, $\mathrm{QO}_{2}$ does not show any variation distinctly, but $\mathrm{QCo}_{2}$ and RQ are suppressed.

(4) By the injection of desoxycorticosterone acetate, the erythrocyte respiration is remarkably suppressed.

(5) By the bilateral adrenalectomy, the erythrocyte respiration decreases remarkably.

(6) When a small quantity of testosterone propionate was injected on the male rabbits, the erythrocyte respiration is enhanced, but on the female this tendency is not distinct.

(7) By the extirpation of the testicles, the erythrocyte respiration decreases after long time. (about fifty days).

(8) When a small quantity of estradiol benzoate was injected, the erythrocyte respiration is suppressed. Especially, this tendency is remarkable on the males.

(9) By the extirpation of the ovaries, the erythrocyte respiration was not influenced after long time. (about fifty days).

(10) From the overmentioned results, I can presume that the erythrocyte respiration was influenced by rndocrine functions excepting the effects of the blood regeneration showed by the variations of reticu'ocyte count.

\title{
Measurement of Serum Ins alin Activity and the Investigation about the Nature of Diabetes Mellitus
}

\author{
By
}

\section{Kentaro OKUMURA}

1st Department of Medicine, Kyoto Pref. Univ. of Med. (Director: Associate Prof. H. Yoshida, M.D.)

1) The author investigated about the measurement of serum insulin activity, on the basis of Gemmill's observation, that the isolated rat diaphgram uptakes glucose in the glucose containing solution and the glucose uptake is increased by the addition of insulin to the solution.

2) Wistar strain rats were bred about for 7 days with solid food (Oriental Co. made) under the condition of temperature $22 \pm 5^{\circ} \mathrm{C}$, and were abstained from the food for 15 hours before experiment.

3) These rats were sacrificed by decapitation, and the diaphragms were immediately removed, each of them were dissected in 4 pieces. So-called "quartardiaphragm technique of pooled method" was used for this investigation.

4) Phosphate buffer solution containing $200 \mathrm{mg} / \mathrm{dl}$. sugar was used for medium. For the incubator, the author used the manometer flask of Warburg's apparatus. The flask contains one-fourth of diaphragm, medium and $95 \sim 100 \% \mathrm{O}_{2}$, incubated for 75 minutes at $38^{\circ} \mathrm{C}, 90$ rounds shaking per minute. 


\title{
内分泌腺機能と赤血球呼吸病理に関する実験的研究
}

\author{
京都府立医科大学內科学教室（指導 故舘石教授） \\ 研究科学生右橋 俊 雄
}

（本諭文の要旨は昭和34年 4 月第21回日本血液学会総会に於て発表した。）

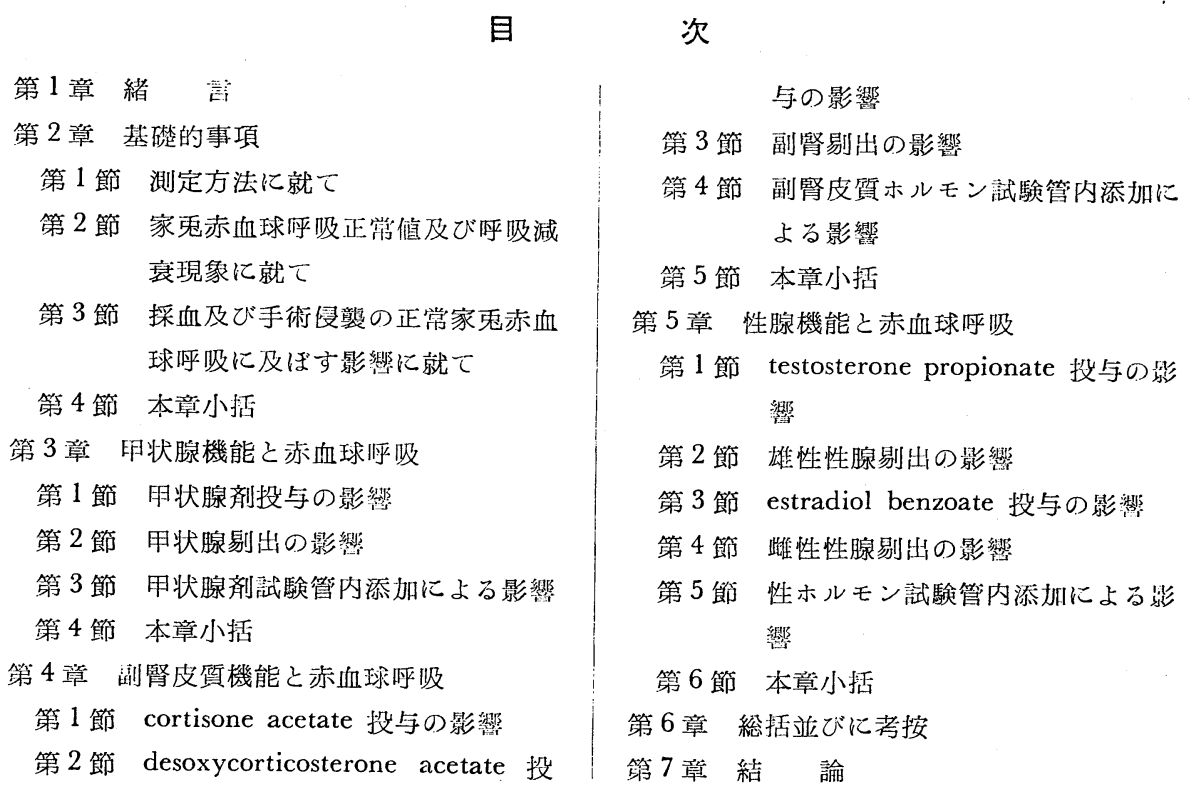

\section{第一章 緒}

言

生体はその生活に必要なる酸奨を肺より摄取し細胞に於て消費するものである。酸絜消費量により示され る細織呼吸ぶ生体細胞内に於ける多数の醅素群による複雑な酸化還元反応による物澌代謝の総和として理解 され数多くの研究報告があるが近時醉素化学, 細胞形態学等の著しい進歩に伴い細胞の物澌代謝研究は醉沙

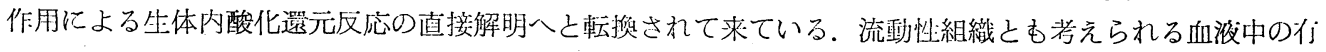
形成分の大部分を占める赤血球の呼吸に関しても同様な事が言える. 赤血球は無核であり mitochondria む え無い haemoglobin を多量に含む特殊な分化した細胞であるが近時解糖酪素系を中心とした energy 代㴬 の存在か解明せられ，一方保存血化関する研究から赤血球は生命を有する細胞之して理解されている。呼根 酩素系に就ても多くの知見が明らかにされて来ているか酒素化学の進歩にも拘らず赤血球の酸素消費機転に 関与る複雑な酵素系の綜合的機能活䣦を十分に説明出来ない現状である.

赤血球甲酸素消費機転に関する諸説を顧るに1875年 Pfüger ${ }^{1)}$ が血管外に取出された血液が酸素消費を行

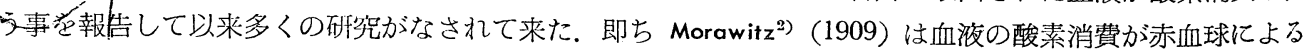

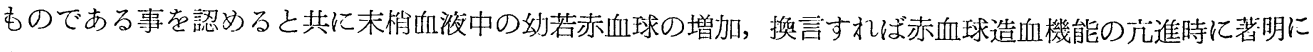
增大する事を報告しこの赤血球酸素消費量の增加が主として網状赤血球乃至多染性赤血球の增加によるもの であろうと述べたが同様の報告は Warburg ${ }^{3)}$ (1910)，伊丹年（1910)， Harrop ${ }^{5)}$ (1919), Denecke ${ }^{6)}$ (1923)， 
山本 ${ }^{8)}$ (昭和10年) 等多くの人々により行われている. Warburg は赤血球の酸素消費機轱に関し haemoglobin が Atmungsferment として作用すると述べ細胞内酸化作用に与る鉄は Hämin 及びその誘導体で あると述べている．山本は幼若赤血球欠除状態のコラルゴール貧血家鬼に於ては瀉血貧血，フェニールヒド ラジン顊血等の㓜若赤血球増加時に比し酸菜消費量の僅微な事を述べている。 Fries ${ }^{9}$ (1911) は血淮の酸素 消費を解糖作用による乳酸発生により説明して居り東 ${ }^{10)}$ (昭和 6 年), Damble ${ }^{11)}$ (1933) 等屯若㓜赤血球の 增加之解糖作用及び酸素消費の亢進が関連を有する事を述べている. 解糖作用は成熹赤血球の主要な物質代 謝であるが Bornstein u. Ascher ${ }^{12)}$ 等は解糖作用之赤血球内酸化機構が本質的に異なるものであると述べてい る. Batteli u. Stern ${ }^{13)}$ は血液による主呼吸之酥素作用による副呼吸の存在する事及び溶解亦血球の酸素消費 が血色素によるものであろうと述べている．Lövgren ${ }^{14)}$ は血色素が oxydationskatalysator として働くと見做 して居る. 赤血球の酸素消費機転に対する血色素の作用に関連して溶解赤血球の酸素消費に就ても多くの報 告があるが山本は血色素溶液及び stroma 浮游液に対する肝エキス添加実鈳より血色素溶液の酸素消費量は 大であるが肝エキスによる酸素消費促進作用は stroma 浮游液にあると述べ，大橋卓む同様に $0.3 \% \mathrm{NaCl}$ 溶液による溶解赤血球の stroma 浮游液に血色素溶液の10倍の酸素消費を認めている. 石関 ${ }^{16)}$ は種々の重曹

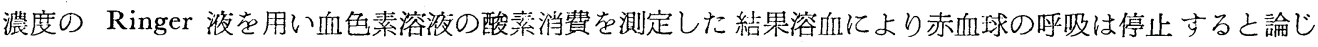
山來 ${ }^{17)}$, Hattingberg ${ }^{18)}$ 等の言う血色素による酸素消費を否定している. Bartlett \& Marlow ${ }^{19}$ は赤血球の呼 收を全て混在した白血球及び網状赤血球の:作用として説明がつくとして居るが Denstedt ${ }^{20)}$ は血液が保存に より酸化 haemoglobin より還元 haemoblobin へと変る事及び CN を加えると還元 heamoglobin になり

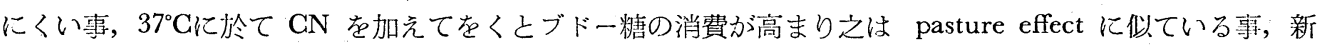

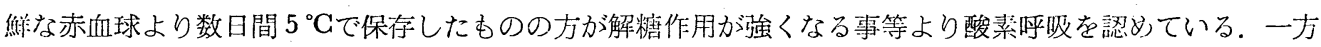
Dajani \& Orten ${ }^{21)}$ は有核鷄赤血球及び热核牛赤血球を用い赤血球内水溶性カルボキシル酸の全分析を行い成 熟牛赤血球内には Krebs cycle の存在を否定して居る. 以上の如く成熟赤血球の呼吸機構に関しては未だ 完全な解明に详していない様である.

赤血球の酸素消費量が赤血球の年令乃至造血機能の強弱にのみ左右されるのではなく多くの既知，未知の 因子により影響される事が報告されて㕍る. 即ち1928年 Harrop u. Barron22) は methylenblau が赤血球呼 吸を増加せしもる事を報告し methylenblau が無核赤血球に实て消失した物䓄買を補つて $\mathrm{O}_{2}$-carrier として の役割を舆すと説明している．次で Michaelis u. Salomon ${ }^{23)}$ は肝，脾エキスに赤血球呼吸促進作用のある事 足報告し, その後 Zeile u. Euler ${ }^{24)}$, Deutsch u. Wagenfeld ${ }^{25)}$, Damble, 山本等により同㥞の事笑方報告されて いる. 糖類添加により赤血球酸素消費量が影響を受ける事も幾多報告せられている。即ち角本 ${ }^{26)}$ は健康者赤 I血球酸素消費量がブド一糖加 Ringer 液中に於て増加し殊に $3 \%$ \%に於て最大であるとしている，Horn u.

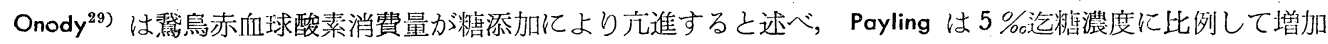
すると述べている．後藤 ${ }^{29}$ は保存血の酸素消費量を測定し糖濃度 $1.5 \%$ 以下のものは促進せしぬると報告し ている．浅川 ${ }^{30}$ は生理的食塩水浮游液に $1 \%$ 割合にブドー糖を加えると刘照の 2 倍の酸素消費を見ると达 ベている. 伊藤 ${ }^{31)}$ は0.4\% ブドー糖添加により酸素消費の促進を認めこの際 phosphate の存在が必要で, $\mathrm{NaHCO}_{3}$ では糖効果屾起らないと述べ同時に 2，3 陽イオンの影嚮を検討し $\mathrm{K}, \mathrm{Ca}, \mathrm{Ba}$ は抑制的に $\mathrm{Na}$ は $0.9 \%$ 以上で促進的に働くと報告している。本松 ${ }^{32}$ は之を追試してブドー糖，果糖には糖效果を認めるが 蔗糖, arabinose には之を認めず,,同時に KCN は赤血球の酸素消費と共に糖效果を停止せしぬ, 2,4-DNP (dinitrophenol) は Ringer 液中では酸素消費に影響なく，ブドー糖加 Ringer 淮中では対照に比し酸素消 蛽が高まり，又 acetylcholine は糖效果を抑制すると述べている．以上諸家の報告より見てブドー糖添加が 組織呼吸に於ける場合之同様に赤血球呼吸に於てあ酸素消費を促進せしめるあのと思われる，その他各種楽

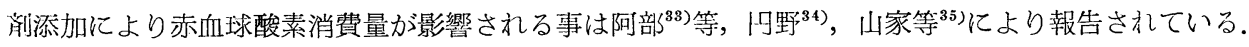

一方之ら糖類，塩類，各種薬䠼等の in vivo, in vitro の添加実験に就ての報告と共に各種疾息洔に於け る赤血球呼吸の变動に関する報告も多数見受けられる。即ち肺機能の影響に関しては Roessingh ${ }^{36)}$, 山本，吉 田 ${ }^{37}$ )等は肺結核症に就て赤血球呼吸の低下を報告し, 宮崎 ${ }^{38}$ は之蛋脑機能障碍実験により詳しく検索し, 伊 
藤 ${ }^{39}$ は肺の外科的侵襲時の赤血球呼吸に関し臨床的報告を行つている。肺機能と共に肝機能が赤血球呼吸に

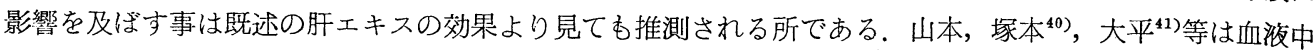

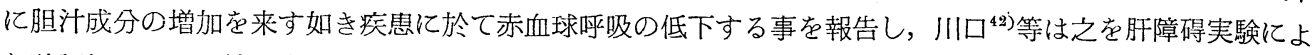
り確認している．糖尿病䎲就て角本は健康者に比し糖尿病患者に於ては赤血球呼吸の低下する事を報告した が，川口等は之を追偝し同様の減弱㑯向を認めると共に Alloxan 糖永家鬼の高血糖期に於て赤血球呼吸の 艺進傾向を報告している，その他恶性腫演，血液疾患，発熱時 ${ }^{41)}$ 等に於ける赤血球呼吸の变動や動物種属に よる差異 ${ }^{45}$ ，八インツ氏小体保有赤血球の呼吸 ${ }^{37}$ 等に関しても幾多の報告があり赤血球呼吸に影響を及ぼす 因子の多様性を示している.

以上の事実より著者は生体の物質代謝及び造血機能々強い関連性を有する内分泌腺機能の赤血球呼吸に及 ばす影響を㭘索し赤血球呼吸病理の一端を解明せんとして本実験を行つたすのである. 赤血球か酸素消費と 共に炭酸ガス放出を行う事は Horrop \& Barron の報告以来明らかであるが教室の吉田, 宫崎, 伊藤，川口等 は酸素消費量及び炭酸ガス放出量の同時測定を行い恩師故舘石教授は赤血球呼吸病理の正確な把握には両者 の測定が必要な事を力説せられている．吉田等は試験管内に於てハインツ氏小体を出現せしめた場合の赤血 球乎吸は刘照に比し酸素消費量に於て約 6 割となり炭酸ガス放出量に於て約 1 割となり殊に放出炭酸ガス舅 の堿少が著明であると報告している。宮崎は重症肺結核症の赤血球呼吸は酸素消費量の堿少之共に放出炭酸 ガス量の著减を認め呼吸商の低下を示してをり，又家鬼による実験的肺機能障碍時の赤血球呼吸を測定し同 樣に酸素消費量之炭酸ガス放出量が併行して変動するすのでない事を実証している.

糿一方内分泌腺が生体の物斦代謝に強い影響を及ぼす事より内分泌腺機能失調時の赤血球呼吸測定に当つて は種々の問題を考慮しなければならないが殊に造血機能を介する影響に就ては既述の如く赤血球呼吸が造向 機能之強い関連性を有する事より著者は赤血球呼吸測定と併行して未悄血中の網状赤血球数, 赤血球数, 血 色素量の測定を行いその変動と共に内分泌腺機能の赤血球呼吸病理に及ぼす影響を検討し 2,3 知見を得た のでここに報告する.

\section{第二章 基 礎 的 事 項}

\section{第 1 節 測定方法に就て}

（1）赤血球呼吸の測定には Warburg 氏単一検圧計を 使用した ${ }^{46)}$. U 字状毛細管の内径約 $1 \mathrm{~mm}$, 両誹 $30 \mathrm{~cm}$ の間に $1 \mathrm{~mm}$ 每に 300 目盛を施したものである。開鎖液には Brodie 液を使用した. Brodie 液の处厅 は下記の如くで之に防窗の目的で thymol 400mg を1 ccの局方 alcohol に溶解の上加える.

$$
\left\{\begin{array}{lr}
\text { Natrium choleicum } & 5.0 \mathrm{gr} \\
\mathrm{NaCl} & 23.0 \mathrm{gr} \\
\text { Aq. dest. } & 500.0 \mathrm{cc}
\end{array}\right.
$$

Brodie 没溜圧 $10.000 \mathrm{~mm}$ は水銀柱 $760 \mathrm{~mm}$ に相当する. 容器は 1 個の副室と 1 個の側室を有する容 積約 $10 \mathrm{cc}$ のものを使用した。内腔は酸素充媜とし恒温槽の温度は $38^{\circ} \mathrm{C} \pm 0.1^{\circ} \mathrm{C}$ 亿温度調節器にて調節，振潔 速度は每分 100 迴転とした．室温 $20^{\circ} \mathrm{C} \sim 25^{\circ} \mathrm{C}$ 亿て常時測定を行つた.

（2）実験動物として体重 2.5 3.5 kg の成熟家鬼を豆窝糟，野菜にて数日間飼育の上実験に供した，採血 は原則として午前中の空腹時に一定し，被検動物を仰臥位に固定の上，左前胸部を剪毛し，予め $3.8 \%$ ク ン酸ソーダを予定採血量に対し $1 ： 4$ の割合に入れた隇菌注射器にて左前胸部第 3 一第 4 肋間腔より左心血 pro kg 2.5cc の割合にて採取する. 之を直ちに 2,000 迴転 5 分間の遠心沈溊操作を 3 回行つて血槳，白血 球，血小板及び網状赤血球を略完全に除去する，洗條液は浮游液と同じものを用いる．以上の操作により得 られた成熟赤血球の $50 \%$ 均等浮游液を作成しこの $2 \mathrm{cc}$ を実験に供した。同時に乾燥血液重量を $0.1 \mathrm{mg}$ 迄正碓 に測定し呼吸係数を算定した。

（3）赤血球呼吸測定用浮游液としては種々の組成のあのが用いられているが，重曹を含む浮游液は炭酸ガ

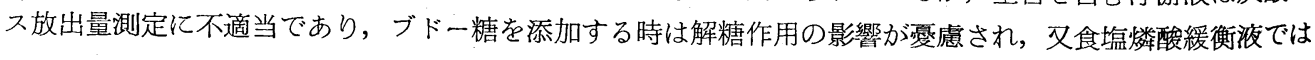


呼吸係数が低い，著者は宮崎 ${ }^{38}$ の比較検討の結果に従い重曹を加えない Ringer 液を用いた。关の組成は下 記の如くである.

$$
\left\{\begin{array}{l}
9.0 \mathrm{gr} / \mathrm{dl} \mathrm{NaCl} 100 \mathrm{cc} \\
11.5 \mathrm{gr} / \mathrm{dlKCl} \quad 2 \mathrm{cc} \\
12.2 \mathrm{gr} / \mathrm{dl} \mathrm{CaCl}_{2} 2 \mathrm{cc}
\end{array}\right.
$$

各溶液を使用の都度混合調製した。本浮游液の $\mathrm{pH}$ は $6.4,50 \%$ 血球浮游液の $\mathrm{pH}$ は 6.8 である。

(4) 赤血球呼吸測定には 2 個の容器を使用し，その各々に $50 \%$ 赤血球浮游液 $2 \mathrm{cc}$ 宛を入れ，第一の容器の 副室には $10 \% \mathrm{KOH} 0.2 \mathrm{cc}$ を入れ第 2 の容器の副室には何も入れない. 之らの容器を manometer に密着 の上酸素を通じ容器内を飽和せしめた後 $38^{\circ} \mathrm{C}$ 恒温槽に入れ温度及び圧が平衡に達した後（15分後）測定を 開始し 1 時間の酸素消費量及び炭酸ガス放出量を測定した。酸素消費量 $\mathrm{XO}_{2}$, 炭酸ガス放出量 $\mathrm{XCO}_{2}$ は 次の式により計算される.

$$
\begin{aligned}
& \mathrm{XO}_{2}=\mathrm{H}_{\mathrm{I}}\left(\mathrm{KO}_{2}\right) \mathrm{I} \\
& \mathrm{XCO}_{2}=\left[\mathrm{H}_{\text {II }}-\frac{\mathrm{XO}_{2}}{\left(\mathrm{KO}_{2}\right)_{\text {II }}}\right]\left(\mathrm{KCO}_{2}\right)_{\text {II }}
\end{aligned}
$$

$\mathrm{H}_{\mathrm{I}}$; 第一の検压棓左脚の読み

$\mathrm{H}_{\text {II }}$; 第二の検圧計の左脚の読方

$\left(\mathrm{KO}_{2}\right)_{\mathrm{I}}$; 第一の検圧計の酸素汇関する容器恒数

$\left(\mathrm{KO}_{2}\right)_{\text {II }} ;$ 第二の検圷計の酸素に関する容器恒数

$\left(\mathrm{KCO}_{2}\right)_{1}$; 第二の検圧計の炭酸ガスに関する容器恒数

呼吸係数 $\mathrm{QO}_{2}, \mathrm{QCO}_{2}$ は次の式により算出する.

$$
\mathrm{QO}_{2}=\frac{\mathrm{XO}_{2}}{\mathrm{mt}} \quad \mathrm{QCO}_{2}=\frac{\mathrm{XCO}_{2}}{\mathrm{mt}}
$$

$\mathrm{m}:$ 赤血球乾燥重量 $(\mathrm{mg})$

$\mathrm{t}$ : 測定時間 ( 1 時間)

上記の Warburg 直接法による $\mathrm{QCO}_{2}$ 及び $\mathrm{RQ}$ の測定に当つては 2 個の容器の気相及び 液相中の炭酸 ガス濃度の差異及び放出炭酸ガス量の他に液相中結合炭酸量を加えねばならないが宮崎 ${ }^{38}$ の検討に上れば結 合炭酸量は微量であり, 且同一条件の下で実験が行われる場合には炭酸ガス放出量の大略を知り実験成績を 比較検討する上に大した支障のないもの之考えられるので本研究に於ては結合炭酸量は省略し該方法に従つ て実験を行つた。

（5）家鬼末梢血液像は耳静脈採血にて赤血球呼吸測定用採血の直前に測定した。網状赤血球数は $1 \%$ ゔ ラントクレシルブラウ加生食水による新鮮標本を用い計測し, 血色素量は Sahli- 小宮氏法によつた.

\section{第 2 節 家兔赤血球呼吸正常值及び呼吸減衰現象に就て}

(1) 前節既述の方法による正常家禹赤血球呼吸及び末梢血液像は第 1 表の如くである.

第 1 表の $\mathrm{QO}_{2}$ と網状赤血球数の相関係数は +0.374 であり, $\mathrm{QCO}_{2}$ 之網状赤血球数とは +0.370 であり 正常家鬼に於ては赤血球呼吸と末梢血中網状赤血球数とは有意の相関関係を示さない. 猶著者と同一方法に

第 1 表 正常家禹赤血球呼吸（左心血）及び末梢血液像

\begin{tabular}{c|c|c|c|c|c|c|c|c}
\hline & 例 数 & $\mathrm{QO}_{2}$ & $\mathrm{QCO}_{2}$ & $\mathrm{RQ}$ & $\begin{array}{c}\text { 網状 } \\
\text { 赤血球数 }\end{array}$ & 赤血球数 & 血色溸量 \\
\hline 全 & 35 & 0.072 & 0.071 & 0.986 & $16.3 \%$ & $541.5 \times 10^{4}$ & $85.0 \%$ \\
古 & 31 & 0.073 & 0.073 & 1.000 & 17.6 & 529.7 & 82.4 \\
\hline 総平均 & 66 & 0.072 & 0.072 & 1.000 & 16.9 & 536.9 & 83.8 \\
偏 差 & & 0.009 & 0.009 & & 6.6 & 21.5 & 4.0 \\
\hline
\end{tabular}


て測定せる宮崎の正常家鬼左心血赤血球呼吸測定値は $\mathrm{QO}_{2} 0.059, \mathrm{QCO}_{2} 0 \cdot 060, \mathrm{RQ} 1.02$, 右心血は $\mathrm{QO}_{2}$ 0.046, $\mathrm{QCO}_{2}$ 0.054, RQ 1.17 であり左心血に於て $\mathrm{QO}_{2}$ の高值を認めている.川口年) は正常家象左心血の $\mathrm{QO}_{3} 0.072, \mathrm{QCO}_{2} 0.072, \mathrm{RQ} 1.01$ を示してをり著者の得た成繢は之に一致し，且雌雄間に善異を認めなか 地。

（2）有核赤血球の酸絜消費量が時間の経過と共に直線的に增加し呼吹減衰現象を示さない事は清水 ${ }^{47}$ 亿よ り指摘された所であるが, 人赤血球の酸素消費量が時間の経過と共に著明な減少を示す事は角本 ${ }^{20)}$, 後藤 ${ }^{29}$, 宮崎 ${ }^{38}$ 等により示されてをり後藤は呼吸娍衰率 $\mathrm{R}_{2} \mathrm{Q}$ を提称している。一方家鬼赤血球に関し宮崎は 7 時間 後に於ても著明な減衰現象を見ない之述へ，之反し左座 ${ }^{48}$ は人，豚，家鬼，牛，犬，猫，モルモッ卜等に

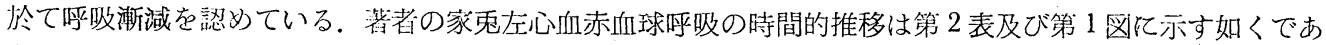
弓.

即ち人静脈血に於ける程落明ではないが家乐左心血に於ても時間推移と共に呼吸減衰現像か認められる。

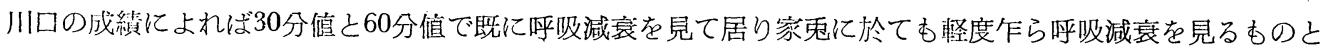
思方机る。

\section{第3 節 採血及び手術唚襲の正常家鬼赤血球呼吸に及ぼす影響に就て}

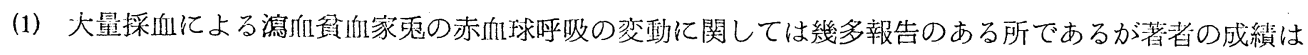
第 3 表及び第 2 図に示亦如くである。

第 2 表 家鬼赤血球呼吸の時閔的推移

\begin{tabular}{|c|c|c|c|c|c|c|c|c|c|}
\hline 萑 例 & 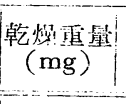 & $\begin{array}{l}\text { 時間 } \\
\text { (分) }\end{array}$ & 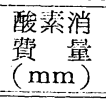 & 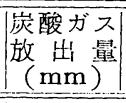 & 症 例 & 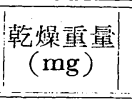 & $\begin{array}{l}\text { 封閪 } \\
\text { (分) }\end{array}$ & $\begin{array}{l}\text { 酸䒚消 } \\
\text { 留 量 } \\
(\mathrm{mm}) \\
(\mathrm{mm})\end{array}$ & $\begin{array}{l}\text { 炭酸ガス. } \\
\text { 放出量 } \\
(\mathrm{mm})\end{array}$ \\
\hline $\begin{array}{c}\text { No. } 151 \\
(\hat{o})\end{array}$ & i98.2 & $\begin{array}{r}30 \\
60 \\
90 \\
120 \\
150 \\
180 \\
210 \\
240\end{array}$ & $\begin{array}{r}8.2 \\
14.9 \\
20.6 \\
25.6 \\
29.5 \\
33.7 \\
38.1 \\
42.3\end{array}$ & $\begin{array}{l}10.4 \\
15.7 \\
19.8 \\
24.3 \\
27.6 \\
31.0 \\
34.7 \\
38.5\end{array}$ & $\left|\begin{array}{c}\text { No. } 154 \\
\text { (우) }\end{array}\right|$ & 286.1 & $\begin{array}{r}30 \\
60 \\
90 \\
120 \\
150 \\
180 \\
210 \\
240\end{array}$ & $\begin{array}{l}14.2 \\
20.5 \\
29.5 \\
38.7 \\
46.5 \\
53.5 \\
60.7 \\
66.2\end{array}$ & $\begin{array}{l}13.6 \\
19.6 \\
28.6 \\
35.2 \\
41.1 \\
49.3 \\
52.5 \\
56.8\end{array}$ \\
\hline $\begin{array}{c}\text { No. } 152 . \\
(\hat{\jmath})\end{array}$ & 232.0 & $\begin{array}{r}30 \\
60 \\
90 \\
120 \\
150 \\
180 \\
210 \\
240\end{array}$ & $\begin{array}{r}8.9 \\
14.5 \\
22.6 \\
30.1 \\
36.7 \\
41.2 \\
44.5 \\
48.3\end{array}$ & $\begin{array}{r}8.4 \\
16.2 \\
21.5 \\
27.0 \\
33.5 \\
38.5 \\
40.8 \\
42.7\end{array}$ & $\begin{array}{c}\text { No. } 156 \\
(\hat{\delta})\end{array}$ & 223.5 & $\begin{array}{r}30 \\
60 \\
90 \\
120 \\
150 \\
180 \\
210 \\
240\end{array}$ & $\begin{array}{r}8.9 \\
15.5 \\
22.6 \\
29.5 \\
35.2 \\
41.5 \\
47.0 \\
52.2\end{array}$ & $\begin{array}{r}9.2 \\
13.2 \\
21.2 \\
27.5 \\
32.3 \\
36.7 \\
41.8 \\
44.5\end{array}$ \\
\hline $\begin{array}{c}\text { No. } 153 . \\
(\hat{\delta})\end{array}$ & 215.4 & $\begin{array}{r}30 \\
60 \\
90 \\
120 \\
150 \\
180 \\
210 \\
240\end{array}$ & $\begin{array}{r}9.2 \\
15.1 \\
22.5 \\
27.4 \\
32.3 \\
36.5 \\
41.8 \\
45.4\end{array}$ & $\begin{array}{r}8.5 \\
14.6 \\
20.5 \\
25.3 \\
29.2 \\
33.6 \\
37.9 \\
40.0\end{array}$ & $\mid \begin{array}{c}\text { No. } 157 \\
\text { (f) }\end{array}$ & 251.1 & $\begin{array}{r}30 \\
60 \\
90 \\
120 \\
150 \\
180 \\
210 \\
240\end{array}$ & $\begin{array}{r}8.9 \\
19.2 \\
31.2 \\
40.2 \\
46.1 \\
51.5 \\
56.1 \\
59.3\end{array}$ & $\begin{array}{l}10.2 \\
18.4 \\
29.1 \\
36.2 \\
39.1 \\
41.2 \\
43.2 \\
45.3\end{array}$ \\
\hline
\end{tabular}



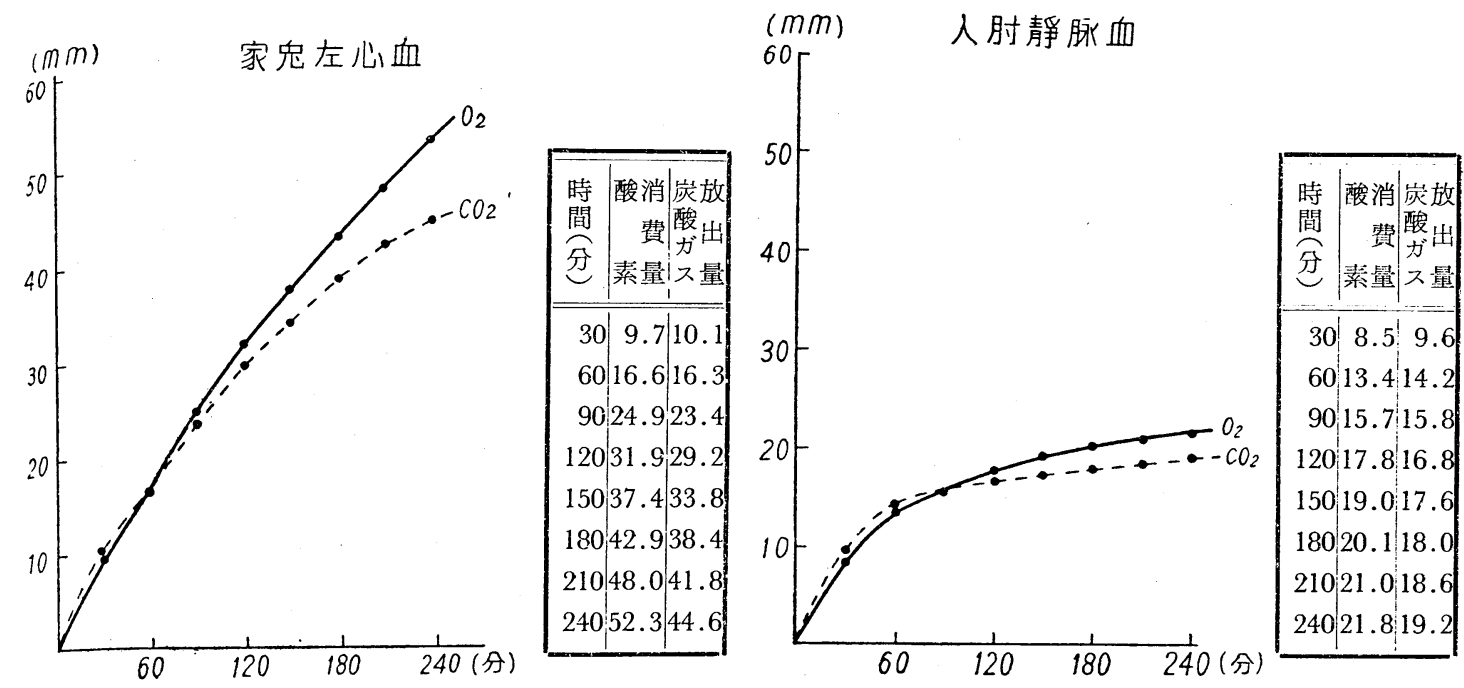

第3表 潟血による変動 (prokg 8cc)

\begin{tabular}{|c|c|c|c|c|c|c|c|c|}
\hline & 例 数 & & $\mathrm{QO}_{2}$ & $\mathrm{QCO}_{2}$ & RQ & 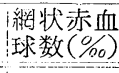 & $\begin{array}{l}\text { 赤向球数 } \\
\left(\times 10^{4}\right)\end{array}$ & $\begin{array}{c}\text { 血色素軖 } \\
(\%)\end{array}$ \\
\hline \multirow{3}{*}{ 前 值 } & \multirow{3}{*}{5} & 平均 値 & 0.068 & 0.068 & 1.000 & 14.6 & 557.0 & 89.4 \\
\hline & & 偏差 & 0.005 & 0.007 & & 8.2 & 27.5 & 5.6 \\
\hline & & 増減率(\%) & 0 & 0 & 0 & 0 & 0 & 0 \\
\hline \multirow{3}{*}{ 第 3 日 } & \multirow{3}{*}{5} & "I & 0.061 & 0.058 & 0.951 & 65.4 & 422.2 & 73.6 \\
\hline & & "I & 0.006 & 0.006 & & 17.2 & 25.4 & 5.2 \\
\hline & & "I & -10.3 & -14.7 & & +348 & -24.2 & -17.3 \\
\hline \multirow{3}{*}{ 第 7 日 } & \multirow{3}{*}{5} & "1 & 0.067 & 0.058 & 0.866 & 99.0 & 403.0 & 74.6 \\
\hline & & "I & 0.009 & 0.006 & & 15.2 & 28.5 & 4.5 \\
\hline & & "1 & -1.5 & -14.7 & & +578 & -27.6 & -16.6 \\
\hline \multirow{3}{*}{ 第10日 } & \multirow{3}{*}{5} & 11 & 0.072 & 0.066 & 0.917 & 52.6 & 442.4 & 78.4 \\
\hline & & "I & 0.008 & 0.005 & & 12.1 & 20.5 & 4.3 \\
\hline & & $" 1$ & +6.0 & -2.4 & & +260 & -20.6 & -12.3 \\
\hline \multirow{3}{*}{ 第14日 } & \multirow{3}{*}{5} & "I & 0.074 & 0.069 & 0.932 & 45.2 & 456.4 & 79.4 \\
\hline & & " & 0.005 & 0.007 & & 15.4 & 18.9 & 5.4 \\
\hline & & " & +8.8 & +1.5 & & +209 & -18.1 & -11.2 \\
\hline \multirow{3}{*}{ 第21日 } & \multirow{3}{*}{5} & "1 & 0.072 & 0.075 & 1.041 & 29.4 & 483.4 & 82.6 \\
\hline & & "1 & 0.007 & 0.006 & & 11.2 & 27.5 & 4.3 \\
\hline & & "l & +5.9 & +10.3 & & +103 & -13.2 & -7.6 \\
\hline \multirow{3}{*}{ 第25日 } & \multirow{3}{*}{5} & "l & 0.071 & 0.069 & 0.972 & 28.4 & 495.0 & 83.0 \\
\hline & & 11 & 0.006 & 0.005 & & 10.3 & 25.0 & 4.7 \\
\hline & & "I & +4.4 & +1.5 & & +95 & -11.0 & -7.2 \\
\hline
\end{tabular}




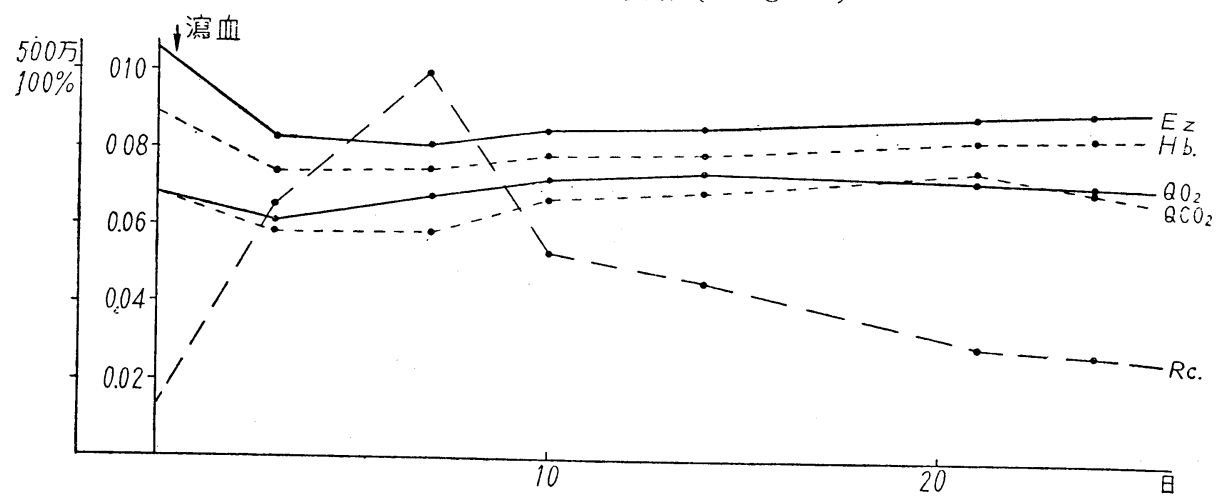

第 4 表 採血対照（prokg 2.5cc）

\begin{tabular}{|c|c|c|c|c|c|c|c|c|}
\hline & 例 数 & & $\mathrm{QO}_{2}$ & $\mathrm{QCO}_{2}$ & RQ & 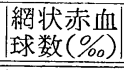 & $\left|\begin{array}{l}\mid \text { 赤血球数 } \\
\left(\times 10^{4}\right)\end{array}\right|$ & $\begin{array}{c}\begin{array}{c}\text { 血色素量 } \\
(\%)\end{array} \\
\end{array}$ \\
\hline \multirow{3}{*}{ 前 値 } & \multirow{3}{*}{5} & 平均 值 & 0.074 & 0.070 & \multirow{3}{*}{0.946} & 18.0 & 550.0 & 84.8 \\
\hline & & 偏美 & 0.007 & 0.005 & & 9.6 & 36.4 & 6.2 \\
\hline & & 増減率(\%) & 0 & 0 & & 0 & 0 & 0 \\
\hline \multirow{3}{*}{ 第 7 日 } & \multirow{3}{*}{5} & "I & 0.073 & 0.064 & \multirow{3}{*}{0.877} & 23.6 & 531.0 & 86.0 \\
\hline & & "1 & 0.006 & 0.006 & & 12.2 & 34.5 & 6.3 \\
\hline & & "1 & -1.2 & -8.6 & & +31.1 & -3.5 & +1.4 \\
\hline \multirow{3}{*}{ 第14日 } & \multirow{3}{*}{5} & "1 & 0.070 & 0.065 & \multirow{3}{*}{0.929} & 20.4 & 520.6 & 82.8 \\
\hline & & ". & 0.006 & 0.007 & & 7.0 & 39.2 & 9.5 \\
\hline & & "I & -5.4 & -7.1 & & +13.3 & -5.4 & -2.3 \\
\hline \multirow{3}{*}{ 第21日 } & \multirow{3}{*}{5} & "I & 0.075 & 0.066 & \multirow{3}{*}{0.880} & 21.8 & 507.2 & 82.8 \\
\hline & & "I & 0.007 & 0.007 & & 6.2 & 13.5 & 3.1 \\
\hline & & "1 & +1.3 & -5.7 & & +21.1 & -7.8 & -2.3 \\
\hline
\end{tabular}

第3図 採血対照 (Prokg 2.5cc)

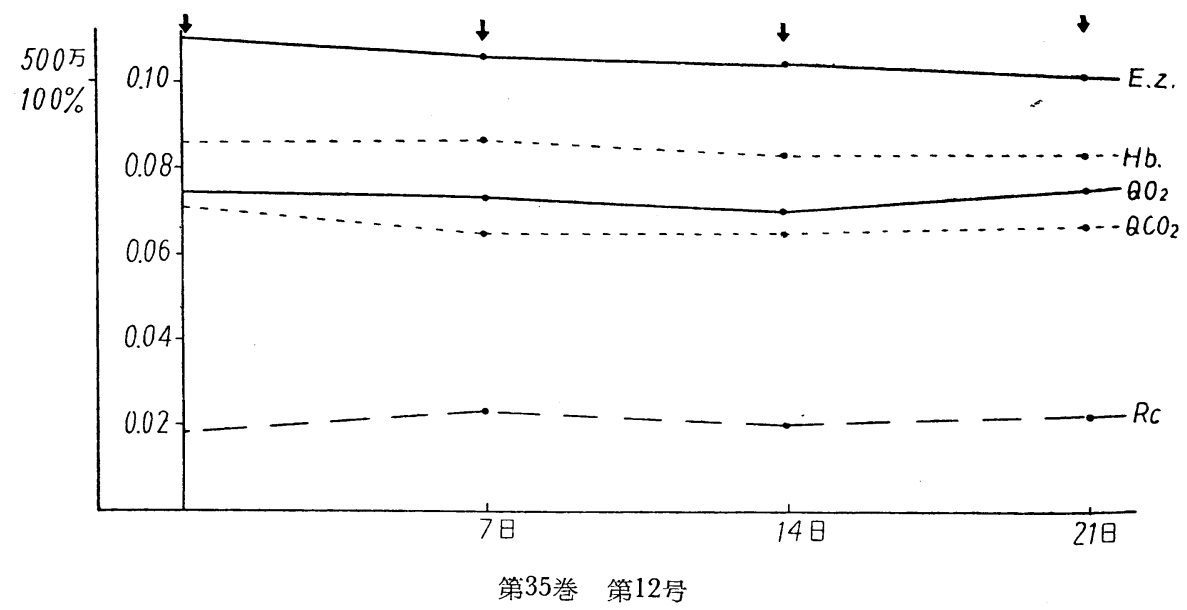


即ち pro kg $8 \mathrm{cc}$ の鴧血をなすと湭血後第 3 日に $\mathrm{QO}_{2}$ は $-10.3 \%, \mathrm{QCO}_{2}-14.7 \%$ の減少を示すがそ の後第10日より第21日に加けて $\mathrm{QO}_{2}+8.8 \%, \mathrm{QCO}_{2}+10.3 \%$ の增加を示した。一方第 3 日, 第 7 日に於て 赤血球数，血色素量は減少するが網状赤血球数は $+578 \%$ の著増を示した。即ち淊血直後に赤血球呼吸は減 弱するが網状赤血球数の増加に稍々遅れて第 7 日以後艺進を示した.

（2）ホルモン剤投与後 1 週間隔 pro kg 2.5cc の少量採血による影響を見る為採血のみによる対照実験を 行つた。 その成績を第 4 表及び第. 3 図に示す.

即ち 1 週間隔 pro $\mathrm{kg} 2.5 \mathrm{cc}$ の採血では赤血球呼吸, 未梢血液像共著明な变化を示さない.

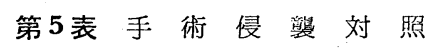

\begin{tabular}{|c|c|c|c|c|c|c|c|c|}
\hline & 例 数 & & $\mathrm{QO}_{2}$ & $\mathrm{QCO}_{2}$ & RQ & 緘状赤 & \begin{tabular}{|l} 
血球数 \\
$\left.\times 10^{*}\right)$ \\
\end{tabular} & $(\%)$ \\
\hline 前 值 & 3 & $\begin{array}{l}\text { 平均值 } \\
\text { 偏 差 } \\
\text { 増減率 }(\%)\end{array}$ & $\begin{array}{c}0.072 \\
0.009 \\
0\end{array}$ & $\begin{array}{c}0.072 \\
0.009 \\
0\end{array}$ & 1.000 & $\begin{array}{c}16.9 \\
6.6 \\
0\end{array}$ & $\begin{array}{c}536.9 \\
21.5 \\
0\end{array}$ & $\begin{array}{c}83.8 \\
4.0 \\
0\end{array}$ \\
\hline 第10日 & 3 & $\begin{array}{l}\text { " } \\
\text { " } \\
\text { " }\end{array}$ & $\begin{array}{r}0.066 \\
0.005 \\
-8.4 \\
\end{array}$ & $\begin{array}{r}0.055 \\
0.003 \\
-23.5 \\
\end{array}$ & 0.836 & $\begin{array}{c}58.0 \\
6.1 \\
+243.2\end{array}$ & $\begin{array}{r}499.7 \\
12.1 \\
-6.3\end{array}$ & $\begin{array}{r}79.7 \\
2.6 \\
-4.9 \\
\end{array}$ \\
\hline 第20日 & 3 & $\begin{array}{l}11 \\
11\end{array}$ & $\begin{array}{r}0.070 \\
0.008 \\
-2.8 \\
\end{array}$ & $\begin{array}{r}0.061 \\
0.008 \\
-15.3 \\
\end{array}$ & 0.871 & $\begin{array}{c}47.0 \\
21.8 \\
+178.1\end{array}$ & $\begin{array}{r}527.7 \\
14.4 \\
-1.7\end{array}$ & $\begin{array}{r}85.0 \\
5.0 \\
+1.4 \\
\end{array}$ \\
\hline 第30日 & 3 & $\begin{array}{l}\text { " } \\
\text { " } \\
\text { " }\end{array}$ & $\begin{array}{l}0.070 \\
0.005 \\
-2.8 \\
\end{array}$ & $\begin{array}{r}0.060 \\
0.006 \\
-16.7 \\
\end{array}$ & 0.857 & $\begin{array}{c}32.3 \\
8.6 \\
+91.1 \\
\end{array}$ & $\begin{array}{r}540.3 \\
20.6 \\
+0.6\end{array}$ & $\begin{array}{c}86.7 \\
5.7 \\
+3.5 \\
\end{array}$ \\
\hline 第40日 & 3 & $\begin{array}{l}1 \\
\text { " } \\
\text { " }\end{array}$ & $\begin{array}{r}0.071 \\
0.004 \\
-1.4 \\
\end{array}$ & $\begin{array}{l}0.065 \\
0.006 \\
-9.7 \\
\end{array}$ & 0.916 & \begin{tabular}{|c|}
28.0 \\
11.1 \\
+65.7 \\
\end{tabular} & $\begin{array}{r}528.3 \\
13.3 \\
-1.6\end{array}$ & $\begin{array}{c}84.0 \\
3.6 \\
+0.2 \\
\end{array}$ \\
\hline 第50日 & 3 & $\begin{array}{l}11 \\
11\end{array}$ & $\begin{array}{c}0.072 \\
0.004 \\
0\end{array}$ & $\begin{array}{l}0.066 \\
0.004 \\
-8.3\end{array}$ & 0.917 & $\begin{array}{c}20.7 \\
5.0 \\
+22.5\end{array}$ & \begin{tabular}{r|}
521.0 \\
11.6 \\
-2.6
\end{tabular} & $\begin{array}{c}81.7 \\
2.9 \\
-2.5\end{array}$ \\
\hline
\end{tabular}

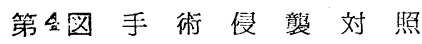

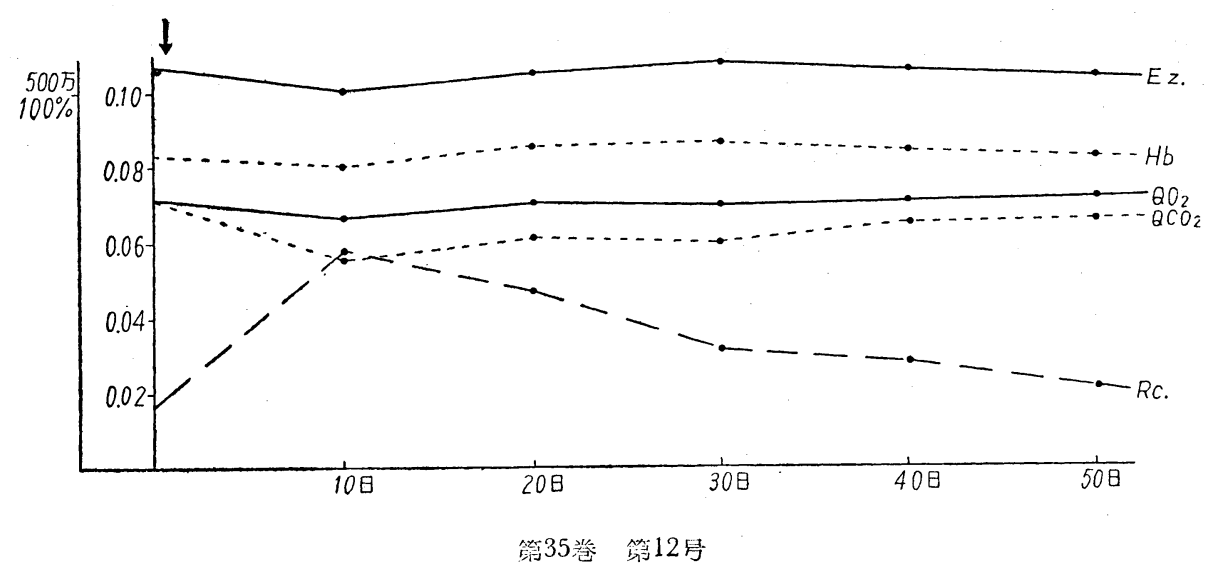




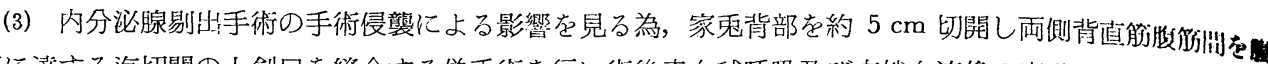
膜に達する迄切開の上創口を縫合する偽手術を行い術後赤血球呼吸及び末梢血液像の变動を観祭した. 之を 第 5 表及び第 4 図に示す。

即ち手術侵襲により $\mathrm{QO}_{2}$ は術後第10日に整度低下を来方がその後は略々前优に復する， $\mathrm{QCO}_{3}$ 法術姼

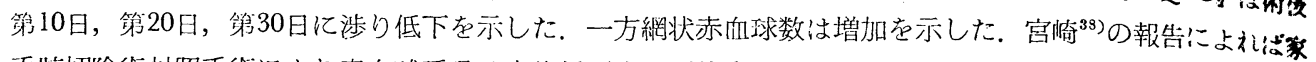

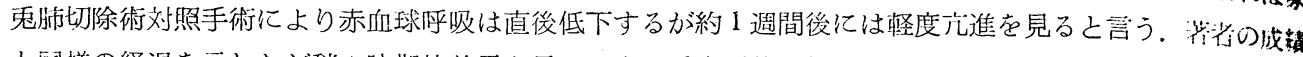
す阔㥞の経過を示したが稍々時期的教買を見る。之は手術侵襲の相遠に起因するむのと思われる。

\section{第 4 節 本章小括}

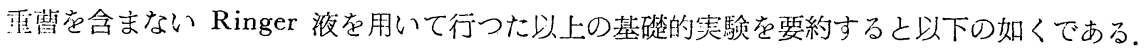

(1) 正常家鬼66例の平均值は $\mathrm{QO}_{2} 0.072, \mathrm{QCO}_{2} 0.072, \mathrm{RQ} 1.000$, 網状赤血球数 $16.9 \%$, 赤价球粦 536.9

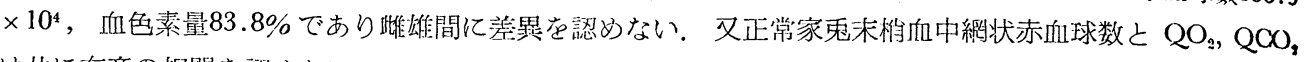
は共に有意の相関を認めない.

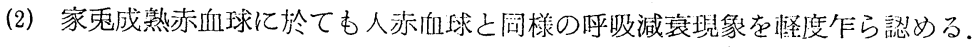

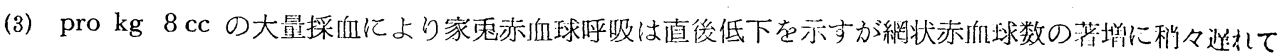
$\mathrm{QO}_{2}, \mathrm{QCO}_{2}$ 共光進在示与。

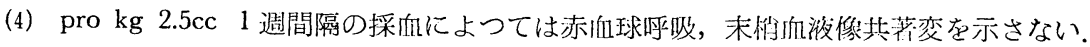

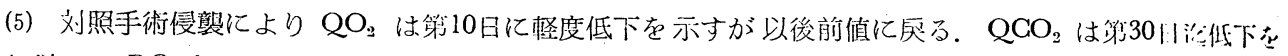
示し分つて RQ も低下する。網状赤吅球数は手術侵襲により增加を来す.

\section{第三章 甲状腺機能と赤血球呼吸}

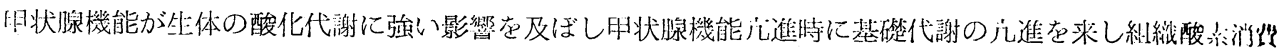

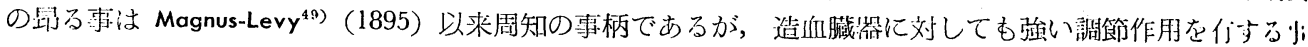

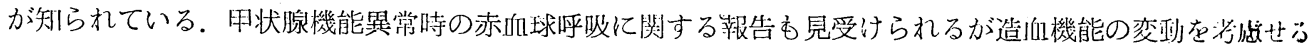

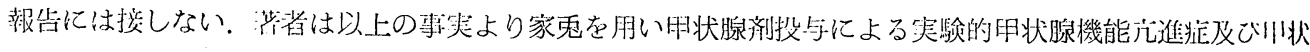

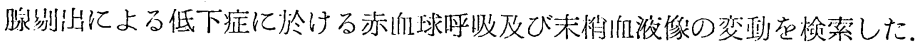

\section{第 1 節 甲状腺剂投与の影響}

第6表 チラヂン $100 \mathrm{mg} 5$ 日間投与群

\begin{tabular}{|c|c|c|c|c|c|c|c|c|c|}
\hline & 家乘潘号 & & $\begin{array}{c}\text { 乾知 } \\
\text { 血淮重 }\end{array}$ & $\mathrm{QO}_{2}$ & $\mathrm{QCO}_{2}$ & $R Q$ & \multicolumn{2}{|c|}{$\begin{array}{l}\text { 絔状永血洂血球数 } \\
\text { 球数 }(\%)\left(\times 10^{2}\left(\times 10^{4}\right)\right.\end{array}$} & 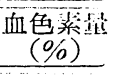 \\
\hline & No. 100 & 令 & $196.5 \mathrm{mg}$ & 0.076 & 0.081 & 1.066 & 13 & 525 & 85 \\
\hline & 99 & $\hat{o}$ & 237.0 & 0.070 & 0.075 & 1.071 & 14 & 520 & 85 \\
\hline & 98 & 令 & 168.0 & 0.083 & 0.074 & 0.891 & 9 & 533 & 90 \\
\hline & 97 & $\hat{o}$ & 186.0 & 0.067 & 0.073 & 1.089 & 17 & 525 & 85 \\
\hline 前 & 96 & 우 & 176.0 & 0.082 & 0.080 & 0.976 & 12 & 510 & 80 \\
\hline Ali & 95 & 우 & 146.0 & 0.081 & 0.108 & 1.333 & 32 & 551 & 80 \\
\hline & 94 & 우 & 140.0 & 0.071 & 0.075 & 1.057 & 28 & 492 & 82 \\
\hline & 93 & $\hat{\delta}$ & 226.8 & 0.074 & 0.061 & 0.803 & 11 & 560 & 91 \\
\hline 健 & 92 & q & 171.0 & 0.064 & 0.071 & 1.109 & 18 & 530 & 83 \\
\hline & 91 & $\hat{o}$ & 178.5 & 0.076 & 0.085 & 1.118 & 13 & 505 & 90 \\
\hline & 平均 & & & 0.074 & 0.078 & 1.054 & 16.7 & 525.1 & 85.1 \\
\hline & 覆 差 & & & 0.007 & 0.012 & & 7.5 & 20.4 & 4.1 \\
\hline & 增娍滀 & & & 0 & 0 & & 0 & 0 & 0 \\
\hline & & & & 第35 & 第 12 & & & & \\
\hline
\end{tabular}




\begin{tabular}{|c|c|c|c|c|c|c|c|c|c|}
\hline \multirow{13}{*}{$\begin{array}{l}\text { 第 } \\
7 \\
\text { 日 }\end{array}$} & No. 100 & $\hat{o}$ & 164.5 & 0.071 & 0.065 & 0.916 & 19 & 519 & 85 \\
\hline & 99 & $\hat{o}$ & 181.0 & 0.107 & 0.076 & 0.710 & 115 & 509 & 84 \\
\hline & 98 & $\hat{\delta}$ & 157.0 & 0.086 & 0.077 & 0.896 & 36 & 544 & 82 \\
\hline & 97 & $\hat{o}$ & 153.0 & 0.105 & 0.082 & 0.781 & 25 & 510 & 80 \\
\hline & 96 & 우 & 186.8 & 0.125 & 0.083 & 0.664 & 86 & 454 & 75 \\
\hline & 95 & q & 184.5 & 0.091 & 0.082 & 0.901 & 68 & 501 & 83 \\
\hline & 94 & 우 & 150.7 & 0.093 & 0.073 & 0.785 & 104 & 496 & 80 \\
\hline & 93 & $\hat{\delta}$ & 150.8 & 0.093 & 0.079 & 0.850 & 85 & 459 & 87 \\
\hline & 92 & q & 206.0 & 0.087 & 0.065 & 0.748 & 49 & 501 & 85 \\
\hline & 91 & $\hat{o}$ & 181.0 & 0.099 & 0.068 & 0.687 & 138 & 467 & 82 \\
\hline & & & & 0.096 & 0.075 & 0.781 & 72.5 & 496.0 & 82.3 \\
\hline & 偏 差 & & & 0.014 & 0.007 & & 40.0 & 28.4 & 3.4 \\
\hline & 增減率 & & & +29.8 & -3.9 & & +370.1 & -3.6 & -3.3 \\
\hline \multirow{13}{*}{$\begin{array}{l}\text { 篚 } \\
\text { 日 }\end{array}$} & No. 100 & $\hat{o}$ & 164.8 & 0.095 & 0.074 & 0.779 & 58 & 445 & 82 \\
\hline & 99 & $\hat{o}$ & 150.0 & 0.090 & 0.079 & 0.878 & 62 & 520 & 80 \\
\hline & 98 & $\hat{\delta}$ & 164.0 & 0.087 & 0.065 & 0.748 & 14 & 436 & 75 \\
\hline & 97 & $\hat{\delta}$ & 151.0 & 0.127 & 0.111 & 0.874 & 102 & 466 & 85 \\
\hline & 96 & + & 196.0 & 0.078 & 0.071 & 0.910 & 64 & 496 & 78 \\
\hline & 95 & 우 & 195.7 & 0.070 & 0.052 & 0.743 & 29 & 543 & 80 \\
\hline & 94 & ㅇ & 166.0 & 0.112 & 0.077 & 0.687 & 69 & 497 & 77 \\
\hline & 93 & $\hat{\delta}$ & 153.0 & 0.118 & 0.079 & 0.669 & 70 & 533 & 80 \\
\hline & 92 & ㅇ & 182.0 & 0.084 & 0.080 & 0.952 & 94 & 508 & 83 \\
\hline & 91 & $\hat{\delta}$ & 181.5 & 0.078 & 0.073 & 0.936 & 51 & 535 & 82 \\
\hline & 平均 & & & 0.094 & 0.076 & 0.809 & 61.3 & 497.7 & 80.2 \\
\hline & & & & 0.019 & 0.014 & & 26.4 & 36.3 & 3.0 \\
\hline & 增減薪 & & & +27.0 & -2.6 & & +267.1 & -3.3 & -5.8 \\
\hline \multirow{13}{*}{$\begin{array}{l}\text { 第 } \\
21 \\
\text { 日 }\end{array}$} & No. 100 & $\hat{\delta}$ & 150.0 & 0.067 & 0.065 & 0.970 & 9 & 497 & 80 \\
\hline & 99 & $\hat{o}$ & 174.5 & 0.079 & 0.063 & 0.798 & 26 & 512 & 92 \\
\hline & 98 & $\hat{\delta}$ & 144.0 & 0.079 & 0.062 & 0.785 & 31 & 503 & 88 \\
\hline & 97 & $\hat{\delta}$ & 157.3 & 0.105 & 0.082 & 0.781 & 51 & 421 & 80 \\
\hline & 96 & 우 & 152.7 & 0.098 & 0.079 & 0.806 & 48 & 533 & 80 \\
\hline & 95 & 우 & 191.0 & 0.068 & 0.067 & 0.985 & 6 & 498 & 83 \\
\hline & 94 & q & 172.5 & 0.089 & 0.079 & 0.865 & 51 & 442 & 77 \\
\hline & 93 & $\hat{\delta}$ & 162.5 & 0.080 & 0.067 & 0.838 & 27 & 523 & 87 \\
\hline & 92 & 우 & 184.6 & 0.080 & 0.071 & 0.887 & 26 & 449 & 83 \\
\hline & 91 & $\hat{o}$ & 178.0 & 0.066 & 0.063 & 0.954 & 23 & 486 & 82 \\
\hline & 平 均 & & & 0.081 & 0.070 & 0.864 & 29.8 & 486.4 & 83.2 \\
\hline & 灀 差 & & & 0.013 & 0.010 & & 16.1 & 37.1 & 4.6 \\
\hline & 增減率 & & & +9.5 & -11.3 & & +78.4 & -5.5 & -2.2 \\
\hline
\end{tabular}

同条件飼资の家鬼を用い甲状腺の機能儿進状態を起さしめ既述の方法沉より赤血球呼吸及び末梢血液像の 泚定を行つた。即ち甲状腺剂として Thyradin (帝国臟器製) を用いホルモン剤の作用機序により大量（100 $\mathrm{mg}$ ) 及び少量 $(20 \mathrm{mg})$ 投与の 2 群に分ち各 5 日間皮下注射し実験的甲状腺機能九進状態を起さしめた後 1 䞏間隔の測定を行つた. 


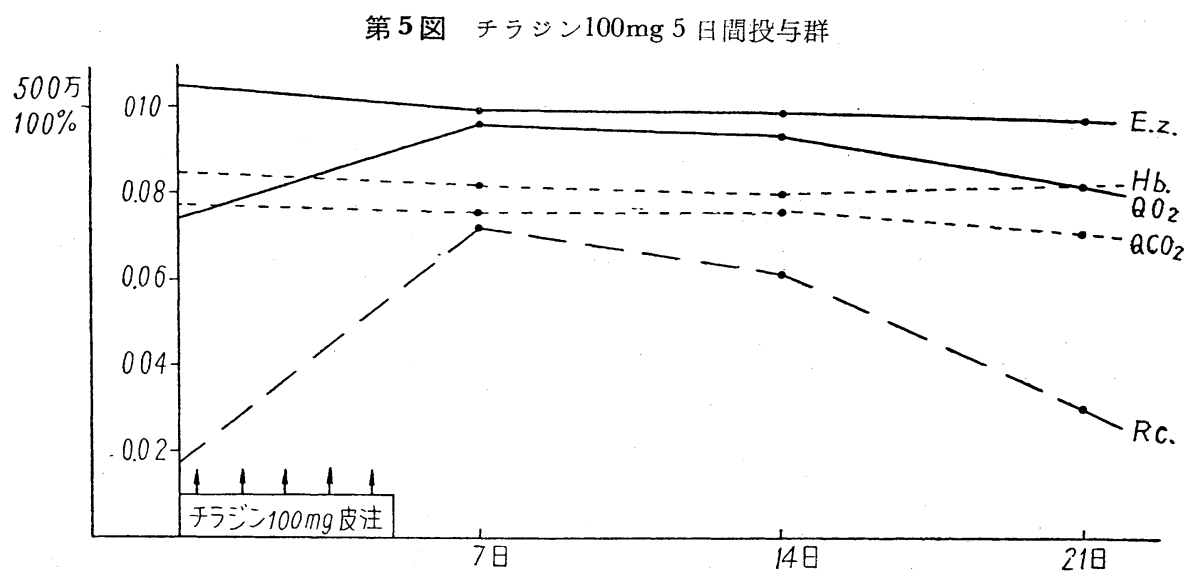

(1) Thyradin $100 \mathrm{mg} 5$ 日間投与による変動

Thradin 大量投与による赤血球呼吸及び末梢血液像の変動は第 6 琶及び第 5 図に示す如くである.

即ち Thyradin 100mg 5 日間投与により $\mathrm{QO}_{2}$ は第 7 日 $+29.8 \%$ ，第14日 $+27.0 \%$ ，第21日 $+9.5 \%$ の 著明な増加を示すが $\mathrm{QCO}_{2}$ は第21日に-11.3\%の低下を示すす著変を認めず従つて RQ の低下を認めた。 網状赤血球数は第 7 日 $+370.1 \%$, 第 14 日 $+267.1 \%$, 第 21 日 $+78.4 \%$ 著明な増加を来すが赤血球数, 血色 素量は著明な増減を示さない.

(2) Thyradin $20 \mathrm{mg} 5$ 日間投与による变動

Thyradin 少量投与による赤血球呼吸及び末梢血液像の変動は第 7 表及び第 6 図に示す如くである。

即ち Thyradin $20 \mathrm{mg} 5$ 日間投与により $\mathrm{QO}_{2}$ は第 7 日 $+11.4 \%$, 第14日+17.1\%の増加死来する $\mathrm{QCO}_{2}$

第 7 表 チラヂン $20 \mathrm{mg} 5$ 日間投与群

\begin{tabular}{|c|c|c|c|c|c|c|c|c|c|}
\hline & 家鬼番号 & & $\mid \begin{array}{l}\text { 乾燥血液 } \\
\text { 重量 }(\mathrm{mg})\end{array}$ & $\mathrm{QO}_{2}$ & $\mathrm{QCO}_{2}$ & $R Q$ & $\left|\begin{array}{l}\text { 網状赤血 } \\
\text { 球数 }(\%)\end{array}\right|$ & $\begin{array}{l}\text { 血球数 } \\
\left(\times 10^{4}\right)\end{array}$ & $\begin{array}{c}\text { 血色素量 } \\
(\%)\end{array}$ \\
\hline \multirow{8}{*}{$\begin{array}{l}\text { 前 } \\
\text { 值 }\end{array}$} & No. 44 & 우 & 158.0 & 0.074 & 0.070 & 0.946 & 9 & 540 & 85 \\
\hline & 43 & 우 & 164.0 & 0.076 & 0.089 & 1.171 & 25 & 526 & 85 \\
\hline & 42 & $\hat{o}$ & 190.0 & 0.065 & 0.061 & 0.938 & 11 & 554 & 80 \\
\hline & 41 & $\hat{o}$ & 195.5 & 0.078 & 0.071 & 0.910 & 25 & 540 & 91 \\
\hline & 40 & $\hat{\jmath}$ & 196.7 & 0.058 & 0.062 & 1.069 & 22 & 514 & 87 \\
\hline & 平均值 & & & 0.070 & 0.071 & 1.006 & 18.4 & 534.8 & 87.6 \\
\hline & 偏 差 & & & 0.008 & 0.012 & & 7.8 & 15.1 & 2.6 \\
\hline & 増減率 & & & 0 & 0 & & 0 & 0 & 0 \\
\hline \multirow{8}{*}{$\begin{array}{l}\text { 第 } \\
7 \\
\text { 日 }\end{array}$} & No. 44 & 우 & 175.3 & 0.085 & 0.076 & 0.916 & 63 & 529 & 84 \\
\hline & 43 & 우 & 155.5 & 0.077 & 0.079 & 1.026 & 120 & 505 & 86 \\
\hline & 42 & $\hat{o}$ & 164.0 & 0.074 & 0.065 & 0.878 & 26 & 513 & 85 \\
\hline & 41 & $\hat{\delta}$ & 194.0 & 0.080 & 0.071 & 0.888 & 54 & 532 & 85 \\
\hline & 40 & $\hat{\delta}$ & 150.3 & 0.072 & 0.069 & 0.958 & 67 & 523 & 85 \\
\hline & 平均値 & & & 0.078 & 0.072 & 0.923 & 66.0 & 520.4 & 85.0 \\
\hline & 偏 差 & & & 0.006 & 0.006 & & 34.3 & 11.3 & 0.2 \\
\hline & 増減率 & & & +11.4 & +1.4 & & +258.7 & -2.7 & -3.0 \\
\hline
\end{tabular}




\begin{tabular}{|c|c|c|c|c|c|c|c|c|c|}
\hline \multirow{8}{*}{$\begin{array}{l}\text { 第 } \\
14 \\
G\end{array}$} & No. 44 & 우 & 175.5 & 0.096 & 0.081 & 0.844 & 34 & 512 & 85 \\
\hline & 43 & 우 & 192.5 & 0.081 & 0.075 & 0.926 & 102 & 493 & 84 \\
\hline & 42 & $\hat{\delta}$ & 190.0 & 0.070 & 0.063 & 0.900 & 68 & 495 & 82 \\
\hline & 41 & $\hat{\delta}$ & 176.5 & 0.097 & 0.093 & 0.959 & 12 & 519 & 80 \\
\hline & 40 & 今 & 187.2 & 0.068 & 0.060 & 0.882 & 37 & 521 & 85 \\
\hline & 平均值 & & & 0.082 & 0.074 & 0.907 & 50.6 & 508.0 & 83.2 \\
\hline & 偏 差 & & & 0.005 & 0.013 & & 35.0 & 13.1 & 2.2 \\
\hline & 増娍率 & & & +17.1 & +4.2 & & +175.0 & -5.0 & -5.1 \\
\hline \multirow{8}{*}{$\begin{array}{l}\text { 第 } \\
21 \\
\text { 日 }\end{array}$} & No. 44 & 우 & 179.5 & 0.068 & 0.060 & 0.882 & 36 & 541 & 84 \\
\hline & 43 & 우 & 176.0 & 0.073 & 0.064 & 0.877 & 27 & 516 & 85 \\
\hline & 42 & $\hat{o}$ & 185.0 & 0.079 & 0.072 & 0.911 & 49 & 504 & 82 \\
\hline & 41 & $\hat{\jmath}$ & 198.0 & 0.065 & 0.051 & 0.785 & 19 & 522 & 86 \\
\hline & 40 & $\hat{o}$ & 160.5 & 0.075 & 0.078 & 1.040 & 35 & 507 & 83 \\
\hline & 平均值 & & & 0.072 & 0.065 & 0.903 & 33.2 & 518.0 & 84.0 \\
\hline & 偏 差 & & & 0.006 & 0.010 & & 11.2 & 11.6 & 1.6 \\
\hline & 增渪率 & & & +2.9 & -8.4 & & +80.4 & -3.1 & -4.1 \\
\hline
\end{tabular}

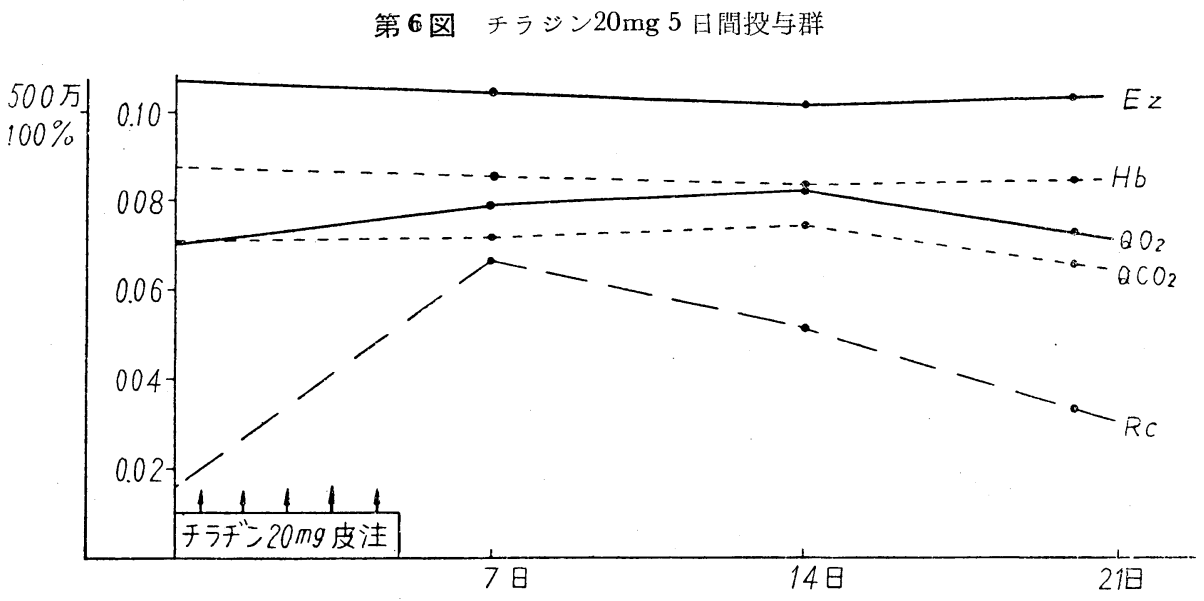

纹蕒変を認めない，網状赤血䇐数は第 7 日 $+258.7 \%$ ，第14日 $+175.0 \% ，$ 第 21 日 $+80.4 \%$ の増加を示すが赤 而球数, 血色素量には著変を認めない.

（3）以上の実験成績より Thyradin 投与により正常家鬼成熟赤血球の $\mathrm{QO}_{2}$ は著明な増加を示す事は明 らかであるが $\mathrm{QCO}_{2}$ は增加せず從つて $\mathrm{RQ}$ は低值を示し，ての傾问は大量投与群に於て一層著明であつ た. 一方網状赤血球数は Thyrodin 投与により著明な増加を示したが赤血球数，血色素量は著变を認めな W.

\section{第 2 節 甲状腺剔出の影響}

甲状腺剔出による実験的甲状腺機能低下症の赤血球呼吸に及ぼす影響を検索する為以下の実験を行つた。 即ち同条件にて飼育せる成熟家鬼を用い型の如く頸部正中切開を行い可及的出血を避けつつ両側甲状腺を全 剔し以後10日間隔にて長期間の変動を観察した。猶実験終了時家鬼血嶈蛋白結合沃度量を測定し甲状腺機能 低下を確認した。笑験成績は第 8 表及び第 7 図に示す如くである. 
即方家鬼甲状腺剔出により $\mathrm{QO}_{2}$ は第10日-4.2\%，第20日 $-2.8 \% ，$ 第 30 日-19.5\%，第40日-18.1\%， 第50日－23.6\%の低下を示し， $\mathrm{QCO}_{2}$ は第10日-16.7\%，第20日-19.5\%，第30日-34.7\%，第 40 日-34.7 $\%$ ，第50日 - $38.9 \%$ の低下を示し従つて RQ む低下する．一方網状赤血球数も術後第 10 日に於て軽度增加 を見るが以後漸減する．赤血球数，血色素量も漸減する．以上の成績を手術侵襲による影響を考虑して見る と甲状腺剔出による $\mathrm{QO}_{2}, \mathrm{QCO}_{2}$ の低下は術後第 30 日より著明であり, 又網状赤血球数，赤血球数，血色 素量共一途渐減する事が認められる。

第 3 節 甲状腺剂試験管内添加による影響

第 8 表 旧 状腺 剔出群

\begin{tabular}{|c|c|c|c|c|c|c|c|c|c|}
\hline 術後 & |家鬼番号 & & \begin{tabular}{|l|} 
乾燥血液 \\
重量 $(\mathrm{mg})$ \\
\end{tabular} & $\mathrm{QO}_{2}$ & $\mathrm{QCO}_{2}$ & $R Q$ & \begin{tabular}{|}
$\mid$ 網状赤血 \\
球数 $(\%)$
\end{tabular} & $\begin{array}{c}\text { 赤血球数 } \\
\left(\times 10^{4}\right)\end{array}$ & $\begin{array}{c}\text { 血色素量 } \\
(\%)\end{array}$ \\
\hline \multirow{11}{*}{$\begin{array}{l}\text { 第 } \\
10 \\
\text { 日 }\end{array}$} & No. 101 & $\hat{\delta}$ & 168.7 & 0.072 & 0.057 & 0.792 & 16 & 536 & 80 \\
\hline & 102 & $\hat{o}$ & 164.0 & 0.057 & 0.049 & 0.860 & 17 & 472 & 77 \\
\hline & 103 & 令 & 177.8 & 0.045 & 0.043 & 0.956 & 8 & 579 & 83 \\
\hline & 104 & 우 & 173.0 & 0.065 & 0.051 & 0.785 & 28 & 515 & 75 \\
\hline & 105 & 우 & 192.5 & 0.090 & 0.071 & 0.789 & 39 & 521 & 83 \\
\hline & 106 & 우 & 187.8 & 0.063 & 0.045 & 0.714 & 31 & 492 & 85 \\
\hline & 108 & 우 & 161.1 & 0.066 & 0.055 & 0.833 & 19 & 551 & 94 \\
\hline & 109 & $\hat{\delta}$ & 195.3 & 0.090 & 0.058 & 0.645 & 23 & 535 & $8 \dot{5}$ \\
\hline & 平均值 & & & 0.069 & 0.060 & 0.869 & 22.6 & 525.1 & 82.8 \\
\hline & 偏 差 & & & 0.015 & 0.011 & & 9.8 & 33.5 & 8.6 \\
\hline & 増減率 & & & -4.2 & -16.7 & & +33.7 & -2.2 & -1.2 \\
\hline \multirow{11}{*}{$\begin{array}{l}\text { 第 } \\
20 \\
\text { 日 }\end{array}$} & No. 101 & $\hat{\delta}$ & 192.5 & 0.096 & 0.080 & 0.834 & 21 & 503 & 80 \\
\hline & 102 & $\hat{o}$ & 171.3 & 0.061 & 0.048 & 0.787 & 13 & 502 & 76 \\
\hline & 103 & $\hat{o}$ & 199.0 & 0.086 & 0.070 & 0.814 & 12 & 506 & 78 \\
\hline & 104 & ㅇ & 175.5 & 0.065 & 0.050 & 0.769 & 11 & 413 & 75 \\
\hline & 105 & 우 & 188.0 & 0.059 & 0.051 & 0.865 & 22 & 519 & 82 \\
\hline & 106 & 우 & 164.2 & 0.057 & 0.052 & 0.912 & 15 & 501 & 80 \\
\hline & 108 & 우 & 173.1 & 0.062 & 0.049 & 0.790 & 17 & 500 & 80 \\
\hline & 109 & $\hat{o}$ & 188.0 & 0.077 & 0.063 & 0.818 & 24 & 517 & 82 \\
\hline & 平均値 & & & 0.070 & 0.058 & 0.829 & 17.0 & 495.2 & 79.2 \\
\hline & 偏 差 & & & 0.014 & 0.012 & & 5.0 & 34.0 & 2.6 \\
\hline & 増減率 & & & -2.8 & -19.5 & & +0.6 & -7.8 & -5.5 \\
\hline \multirow{11}{*}{$\begin{array}{c}\text { 第 } \\
30 \\
\text { 日 }\end{array}$} & No. 101 & $\hat{o}$ & 172.0 & 0.054 & 0.037 & 0.686 & 11 & 467 & 80 \\
\hline & 102 & $\hat{\delta}$ & 170.3 & 0.056 & 0.048 & 0.857 & 7 & 465 & 78 \\
\hline & 103 & $\hat{\delta}$ & 179.5 & 0.065 & 0.051 & 0.785 & 14 & 458 & 77 \\
\hline & 104 & 우 & 185.5 & 0.052 & 0.049 & 0.942 & 10 & 394 & 77 \\
\hline & 105 & 우 & 170.5 & 0.066 & 0.057 & 0.864 & 21 & 528 & 86 \\
\hline & 106 & 우 & 187.5 & 0.061 & 0.046 & 0.754 & 14 & 458 & 80 \\
\hline & 108 & 우 & 153.1 & 0.060 & 0.050 & 0.833 & 9 & 438 & 75 \\
\hline & 109 & $\hat{\delta}$ & 182.2 & 0.050 & 0.037 & 0.740 & 15 & 489 & 78 \\
\hline & 平均值 & & & 0.058 & 0.047 & 0.810 & 12.6 & 462.2 & 78.9 \\
\hline & 偏 差 & & & 0.006 & 0.007 & & 4.4 & 38.5 & 3.3 \\
\hline & 増減率 & & & -19.5 & -34.7 & & -26.0 & -13.9 & -5.8 \\
\hline
\end{tabular}




\begin{tabular}{|c|c|c|c|c|c|c|c|c|c|}
\hline \multirow{11}{*}{$\begin{array}{l}\text { 第 } \\
\text { 日 }\end{array}$} & No. 101 & $\hat{\delta}$ & 190.0 & 0.054 & 0.041 & 0.759 & 15 & 471 & 78 \\
\hline & 102 & $\hat{\delta}$ & 181.5 & 0.061 & 0.046 & 0.754 & 10 & 452 & 78 \\
\hline & 103 & $\hat{\jmath}$ & 167.0 & 0.067 & 0.047 & 0.702 & 10 & 477 & 80 \\
\hline & 104 & 우 & 170.0 & 0.056 & 0.046 & 0.821 & 8 & 415 & 75 \\
\hline & 105 & 우 & 161.0 & 0.055 & 0.043 & 0.791 & 14 & 494 & 85 \\
\hline & 106 & 우 & 165.3 & 0.059 & 0.050 & 0.848 & 11 & 461 & 76 \\
\hline & 108 & 우 & 168.5 & 0.064 & 0.053 & 0.828 & 9 & 440 & 75 \\
\hline & 109 & $\hat{\delta}$ & 179.5 & 0.058 & 0.052 & 0.897 & 19 & 462 & 75 \\
\hline & 兏均值 & & & 0.059 & 0.047 & 0.797 & 12.0 & 459.0 & 77.8 \\
\hline & 䖈 差 & & & 0.006 & 0.005 & & 3.7 & 26.9 & 3.5 \\
\hline & 増減率 & & & -18.1 & -34.7 & & -29.6 & -14.5 & -7.2 \\
\hline \multirow{11}{*}{$\begin{array}{c}\text { 第 } \\
50 \\
\text { 日 }\end{array}$} & No. 101 & $\hat{\jmath}$ & 165.0 & 0.061 & 0.043 & 0.705 & 13 & 452 & 75 \\
\hline & 102 & $\hat{\jmath}$ & 174.0 & 0.053 & 0.040 & 0.755 & 11 & 465 & 78 \\
\hline & 103 & $\hat{\jmath}$ & 193.1 & 0.046 & 0.045 & 0.980 & 8 & 437 & 75 \\
\hline & 104 & 우 & 172.5 & 0.061 & 0.053 & 0.869 & 17 & 425 & 75 \\
\hline & 105 & 우 & 181.5 & 0.052 & 0.037 & 0.711 & 5 & 477 & 83 \\
\hline & 106 & 우 & 160.0 & 0.057 & 0.044 & 0.772 & 14 & 460 & 80 \\
\hline & 108 & 우 & 175.0 & 0.060 & 0.052 & 0.867 & 10 & 425 & 76 \\
\hline & 109 & 令 & 192.0 & 0.047 & 0.039 & 0.830 & 6 & 482 & 80 \\
\hline & 平均値 & & & 0.055 & 0.044 & 0.800 & 10.5 & 452.9 & 77.8 \\
\hline & 偏 差 & & & 0.006 & 0.006 & & 4.2 & 22.5 & 2.7 \\
\hline & 増娍率 & & & -23.6 & -38.9 & & -37.8 & -20.9 & -7.2 \\
\hline
\end{tabular}

註：以下術前値は第 1 表の正常家鬼総平均值を使用する.

第 7 図明状腺 剔出群

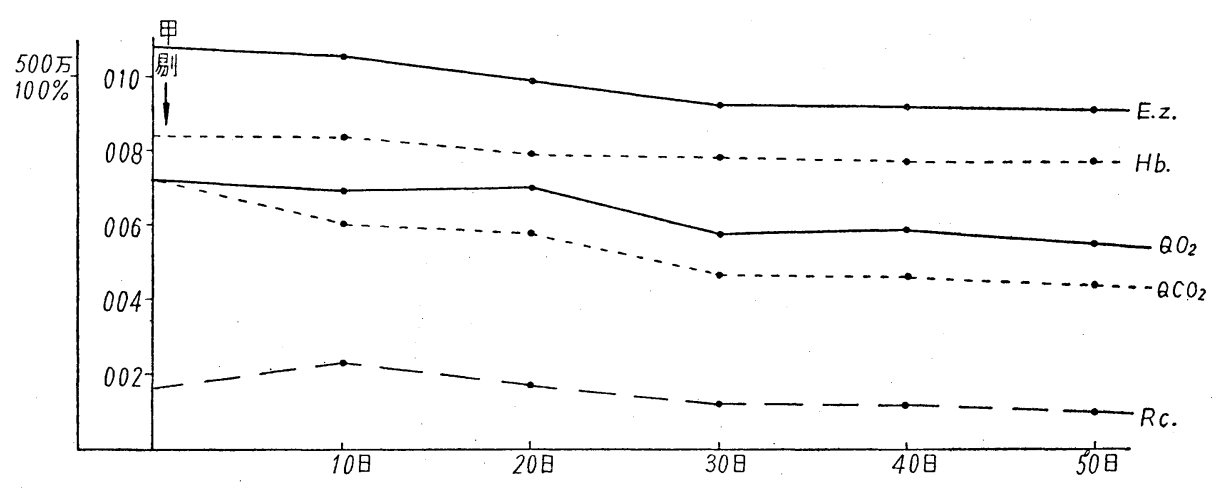

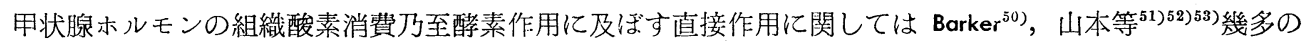

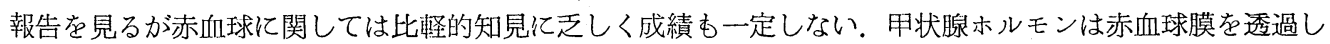
ないとも言われるが併乍ら赤血球呼吸は微量であり実験条件により影響される所が大である．著者の実験方 法による Thyradin 試験管内添加の赤血球呼吸に及ばす影響は第 9 表に示す如くである.

即ち対照群 $\mathrm{QO}_{2}$ 0.068, $\mathrm{QCO}_{2}$ 0.071, RQ 1.044 亿対し Thyradin $0.1 / \mathrm{cc}$ 添加では変化なく, $1 \mathrm{r} / \mathrm{cc}$ 添

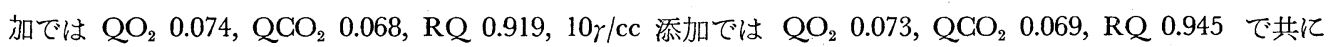


第 9 表 チラヂン試験管内添加実験

\begin{tabular}{|c|c|c|c|c|c|c|}
\hline $\begin{array}{l}\text { チラヂン } \\
\text { 添 加 量 }\end{array}$ & 家匛番号 & & 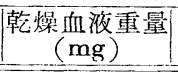 & $\mathrm{QO}_{2}$ & $\mathrm{QCO}_{2}$ & $R Q$ \\
\hline \multirow{5}{*}{ 対照 } & No. 158 & $\hat{\circ}$ & 176.5 & 0.082 & 0.072 & 0.878 \\
\hline & 159 & $\hat{\delta}$ & 191.0 & 0.070 & 0.084 & 1.200 \\
\hline & 160 & 우 & 180.5 & 0.068 & 0.063 & 0.927 \\
\hline & 161 & $\hat{\delta}$ & 154.9 & 0.059 & 0.062 & 1.051 \\
\hline & 162 & \& & 198.0 & 0.062 & 0.075 & 1.210 \\
\hline 平均值 & & & & 0.068 & 0.071 & 1.044 \\
\hline \multirow{5}{*}{$0.1 \gamma / \mathrm{cc}$} & No. 158 & $\hat{\delta}$ & 165.6 & 0.071 & 0.067 & 0.944 \\
\hline & 159 & $\hat{o}$ & 189.5 & 0.065 & 0.065 & 1.000 \\
\hline & 160 & 우 & 171.0 & 0.073 & 0.071 & 0.972 \\
\hline & 161 & $\hat{o}$ & 192.5 & 0.065 & 0.068 & 1.046 \\
\hline & 162 & 우 & 164.3 & 0.076 & 0.069 & 0.908 \\
\hline 应均储 & & & & 0.070 & 0.068 & 0.971 \\
\hline \multirow{5}{*}{$1 \gamma / \mathrm{cc}$} & No. 158 & $\hat{\delta}$ & 188.1 & 0.077 & 0.069 & 0.896 \\
\hline & 159 & $\hat{\delta}$ & 192.5 & 0.065 & 0.071 & 1.092 \\
\hline & 160 & 우 & 165.4 & 0.075 & 0.070 & 0.933 \\
\hline & 161 & $\hat{\delta}$ & 170.0 & 0.071 & 0.063 & 0.887 \\
\hline & 162 & ㅇ & 163.2 & 0.082 & 0.067 & 0.817 \\
\hline 平均偡 & & & & 0.074 & 0.068 & 0.919 \\
\hline \multirow{5}{*}{$10 \gamma / \mathrm{cc}$} & No. 158 & $\hat{\delta}$ & 190.0 & 0.088 & 0.072 & 0.818 \\
\hline & 159 & $\hat{o}$ & 163.5 & 0.070 & 0.079 & 1.129 \\
\hline & 160 & 우 & 184.2 & 0.062 & 0.075 & 1.210 \\
\hline & 161 & $\hat{o}$ & 175.5 & 0.068 & 0.062 & 0.912 \\
\hline & 162 & 우 & 191.3 & 0.058 & 0.055 & 0.948 \\
\hline 平均倠 & & & & 0.073 & 0.069 & 0.945 \\
\hline \multirow{5}{*}{$100 \gamma / \mathrm{cc}$} & No. 158 & $\hat{\delta}$ & 185.0 & 0.076 & 0.055 & 0.724 \\
\hline & 159 & $\hat{\delta}$ & 172.0 & 0.056 & 0.040 & 0.714 \\
\hline & 160 & 우 & 175.0 & 0.070 & 0.069 & 0.986 \\
\hline & 161 & $\hat{\delta}$ & 179.2 & 0.055 & 0.053 & 0.964 \\
\hline & 162 & 우 & 163.5 & 0.053 & 0.048 & 0.906 \\
\hline 承均值 & & & & 0.062 & 0.053 & 0.855 \\
\hline
\end{tabular}

$\mathrm{QO}_{2}$ の微増を認めるが $\mathrm{QCO}_{2}$ は增加せず $\mathrm{RQ}$ は低下うる。100 $/ \mathrm{cc}$ 添加では $\mathrm{QO}_{2} 0.062, \mathrm{QCO}_{2} 0.053$,

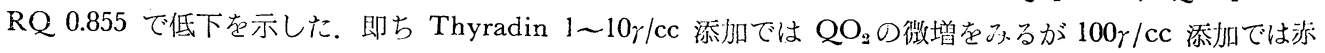
血球呼吸は抑制される。

\section{第 4 節 本章小括}

浾血球呼吸に及ぼす甲状腺機能の影響を以上の成績より要約すると以下の如くである。即ち Thyradin 連続投与により実験的甲状腺機能六進症を惹起せしめた場合，家鬼左心血成熟赤血球の $\mathrm{QO}_{2}$ は著明な增加 を来しての変化は Thyradin 投与中止後も長期間持続する，之に反し $\mathrm{QCO}_{2}$ は著明な増減を示さず從つて $R Q$ あ著明な低下を示す．斯る傾向は Thyradin 大量投与群に於て一層著明である。一方赤血球呼吸に相 
第10表 コーチゾン $5 \mathrm{mg} / \mathrm{kg} 5$ 日間投与群

\begin{tabular}{|c|c|c|c|c|c|c|c|c|c|}
\hline & 家鬼番号 & & \begin{tabular}{|l|} 
乾燥血液 \\
重量(mg) \\
\end{tabular} & $\mathrm{QO}_{2}$ & $\mathrm{QCO}_{2}$ & RQ & $\mid \begin{array}{l}\mid \text { 網状赤血 } \\
\text { 球数 }(\%)\end{array}$ & $\begin{array}{c}\text { 赤血球数 } \\
\left(\times 10^{4}\right)\end{array}$ & $\begin{array}{l}\text { 血色素量 } \\
(\%) \\
\end{array}$ \\
\hline \multirow{10}{*}{$\begin{array}{l}\text { 前 } \\
\text { 值 }\end{array}$} & No. 90 & $\hat{\delta}$ & 209.5 & 0.031 & 0.072 & 0.889 & 19 & 563 & 85 \\
\hline & 87 & $\hat{\delta}$ & 188.0 & 0.089 & 0.080 & 0.900 & 17 & 544 & 85 \\
\hline & 85 & 우 & 185.0 & 0.067 & 0.070 & 1.045 & 9 & 550 & 80 \\
\hline & 83 & 令 & 202.5 & 0.092 & 0.083 & 0.902 & 25 & 567 & 80 \\
\hline & 82 & 우 & 189.7 & 0.081 & 0.075 & 0.926 & 19 & 500 & 85 \\
\hline & 81 & $\hat{\delta}$ & 188.8 & 0.066 & 0.072 & 1.091 & 11 & 530 & 86 \\
\hline & 80 & 우 & 207.0 & 0.080 & 0.085 & 1.063 & 23 & 560 & 85 \\
\hline & 平均值 & & & 0.079 & 0.077 & 0.975 & 17.6 & 544.9 & 83.7 \\
\hline & 偏 差 & & & 0.010 & 0.006 & & 6.0 & 22.4 & 3.2 \\
\hline & 增減率 & & & 0 & 0 & & 0 & 0 & 0 \\
\hline \multirow{10}{*}{$\begin{array}{c}\text { 管 } \\
7 \\
\text { 日 }\end{array}$} & No. 90 & $\hat{o}$ & 193.5 & 0.072 & 0.057 & 0.792 & 45 & 395 & 85 \\
\hline & 87 & $\hat{\delta}$ & 188.3 & 0.066 & 0.044 & 0.667 & 50 & 487 & 77 \\
\hline & 85 & 우 & 167.5 & 0.080 & 0.058 & 0.725 & 45 & 430 & 80 \\
\hline & 83 & $\hat{o}$ & 195.0 & 0.103 & 0.064 & 0.621 & 142 & 394 & 85 \\
\hline & 82 & ㅇ & 164.0 & 0.079 & 0.052 & 0.658 & 16 & 362 & 75 \\
\hline & 81 & $\hat{\delta}$ & 194.5 & 0.081 & 0.058 & 0.716 & 25 & 458 & 80 \\
\hline & 80 & 우 & 199.0 & 0.083 & 0.063 & 0.759 & 33 & 464 & 85 \\
\hline & 艾均值 & & & 0.081 & 0.057 & 0.704 & 50.9 & 427.1 & 81.0 \\
\hline & 垿 差 & & & 0.012 & 0.007 & & 44.2 & 45.0 & 4.0 \\
\hline & 增娍率点 & & & +2.5 & -26.0 & & +189.2 & -21.6 & -3.2 \\
\hline \multirow{7}{*}{$\begin{array}{l}\text { 第 } \\
14 \\
日 \\
日\end{array}$} & No. 90 & $\hat{\delta}$ & 174.5 & 0.061 & 0.042 & 0.689 & 61 & 472 & 80 \\
\hline & 87 & $\hat{o}$ & 207.0 & 0.092 & 0.083 & 0.902 & 66 & 514 & 86 \\
\hline & 85 & 우 & 191.0 & 0.103 & 0.080 & 0.777 & 76 & 406 & 82 \\
\hline & 83 & $\hat{\delta}$ & 199.8 & 0.115 & 0.083 & 0.722 & 109 & 529 & 90 \\
\hline & 82 & 우 & 172.2 & 0.072 & 0.059 & 0.820 & 47 & 478 & 83 \\
\hline & 81 & $\hat{o}$ & 157.0 & 0.088 & 0.056 & 0.637 & 81 & 489 & 85 \\
\hline & 80 & 우 & 163.3 & 0.085 & 0.074 & 0.871 & 58 & 507 & 83 \\
\hline \multirow{13}{*}{$\begin{array}{l}\text { 第 } \\
21 \\
\text { 日 }\end{array}$} & 平均值 & & & 0.088 & 0.068 & 0.773 & 71.1 & 485.0 & 84.1 \\
\hline & 膈 差 & & & 0.018 & 0.017 & & 17.6 & 42.1 & 3.3 \\
\hline & 堌減泫 & & & +11.4 & -11.7 & & +304.0 & -11.0 & +0.5 \\
\hline & No. 90 & $\hat{\jmath}$ & 172.0 & 0.074 & 0.072 & 0.973 & 22 & 470 & 82 \\
\hline & 87 & $\hat{\delta}$ & 175.8 & 0.097 & 0.061 & 0.629 & 41 & 465 & 75 \\
\hline & 85 & 우 & 162.0 & 0.064 & 0.045 & 0.703 & 45 & 514 & 83 \\
\hline & 83 & $\hat{o}$ & 195.0 & 0.061 & 0.063 & 1.033 & 11 & 545 & 80 \\
\hline & 82 & 우 & 159.5 & 0.066 & 0.060 & 0.909 & 12 & 559 & 80 \\
\hline & 81 & $\hat{\delta}$ & 194.2 & 0.073 & 0.064 & 0.877 & 16 & 469 & 84 \\
\hline & 80 & 우 & 187.4 & 0.076 & 0.074 & 0.974 & 16 & 509 & 85 \\
\hline & 平均值 & & & 0.073 & 0.063 & 0.863 & 23.3 & 504.4 & 81.3 \\
\hline & 偏 差 & & & 0.012 & 0.010 & & 14.0 & 35.7 & 3.4 \\
\hline & 増減率 & & & -7.6 & -18.2 & & +21.0 & -7.4 & -2.9 \\
\hline
\end{tabular}




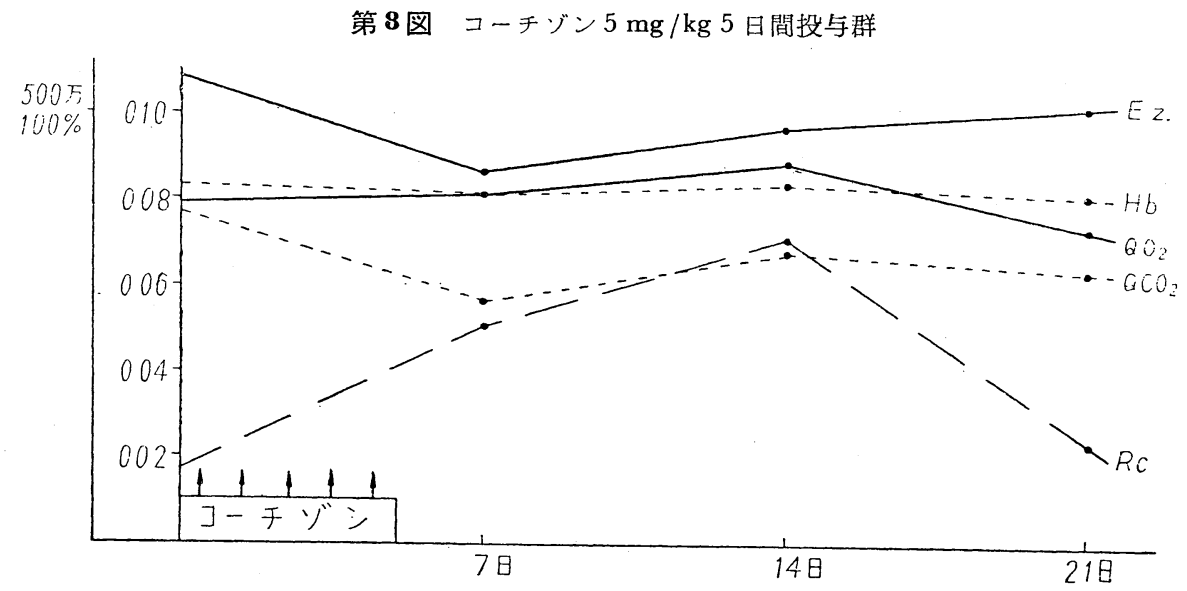

関を有するとされる末梢血中網状赤血球数は Thyradin 投与により著明な增加を示す．赤血球数，血色素 量は採血により軽度堿少を見るも著変を見ない，甲状腺剔出群に於ては赤血球呼吸の低下を来すがての変化 は術後第10日，第20日の測定に於ては手術対照群と比較して差異を見ないが第30日以後に於ては $\mathrm{QO}_{2}$, $\mathrm{QCO}_{2}, \mathrm{RQ}$ の著明な低下を示す。一方網状赤血球数は術後第10日伦て微増を示すが以後第 50 日の測定迄 赤血球数，血色素量と共に渐減傾向が認められる．以上の実験的甲状腺機能充進症及び低下症に於ける経過 より甲状腺の赤血球呼吸に及ぼす影響の大なる事が推測される。

一方 Thyradin 試験管内添加の赤血球呼吸に及ぼす直接作用に於ては1 10 $/ \mathrm{cc}$ 添加により $\mathrm{QO}_{2}$ の微增 をみるも $\mathrm{QCO}_{2}$ 亿は促進効果を認めない. 又100 $/ \mathrm{cc}$ の大量では $\mathrm{QO}_{2}, \mathrm{QCO}_{2}, \mathrm{RQ}$ 共低下し赤血球呼吸の 抑制が認められる。即ち以上の成績より赤血球呼吸が造血機能を介する赤血球の幼若化とは別に直接甲状腺 ホルモンの影響を被る事が推测される。

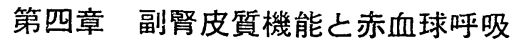

江時下垂体・副腎皮質采機能の生命維持及び物質代謝に及ぼす影響に就ての研究は著しい進歩を遂げ多く の事項が解明されている，組織の酸化代謝に就ての研究報告も多く，副腎皮質が甲状腺之は別途に基礎代謝 苍維持する事が知られている。組織の酸化代謝に及ばす影響は主として副腎剔出実験により検討され臟器に より異つた傾向を示す事が報告されている。一方副緊皮質が血球調節機能を有する事む知られて居る。著者 は以上の事実より比較的知見に乏しい赤血球呼吸及び末梢血液像に及ばす副腎皮質機能の影響を検索せんと して以下の実験を行つた。

\section{第 1 節 Cortisone acetate 投与の影響}

副腎皮質機能旮進状態として glucocorticoids 中 cortison の連続投与による過ホルモン環境を生ぜしもこ の正常家鬼成熟赤血球呼吸及び末梢血液像に及ぼす影響を検索した， cortisone acetate (Cortone 万有) 投 与量は $5 \mathrm{mg} / \mathrm{kg}$ 及び $2 \mathrm{mg} / \mathrm{kg}$ の 2 群に分ち各 5 日間皮下注射した。

(1) Cortisone acetate $5 \mathrm{mg} / \mathrm{kg} 5$ 日間投与による桨動

大量投与群として $5 \mathrm{mg} / \mathrm{kg}$ の cortisone を 5 日間連続投与して赤血球呼吸及び末梢血液像に及ぼす影響 を锥察した. 之を第10表及び第 8 図に示す。

即ち cortison を pro kg $5 \mathrm{mg} 5$ 日間連続皮下注射し 1 週間隔の赤血球呼吸及び末梢血液像の变動を見 ると第7 日に於て $\mathrm{QO}_{2}$ 㹥著変なく $\mathrm{QCO}_{2}$ はー26.0\%の低下を示し $\mathrm{RQ}$ も又 0.704 と低下するが第14日に 於ては $\mathrm{QO}_{2}$ は+11.4\%, $\mathrm{QCO}_{2}$ は-11.7\%の増減を示し第21日に於ては $\mathrm{QO}_{2}, \mathrm{QCO}_{2}$ 共低下傾向を示す。 一方網状赤血球数は第 7 日, 第 14 日共夫々 $+18.2 \%,+304.0 \%$ の著増を示すが赤血球数, 血色素量は第 7 
日に於て夫々 $-21.6 \%,-3.2 \%$ 著明な低下を示し以後渐次前值へと恢復傾向を示した。

(2) Cortisone acetate $2 \mathrm{mg} / \mathrm{kg} 5$ 日間投与による变動

少量投与群として $2 \mathrm{mg} / \mathrm{kg} の$ cortison 5 日間連続投与した場合の赤血球呼吸及び 未梢血液像の变動 落第11表及び第 9 図示す。

即亏 cortison pro $\mathrm{kg} 2 \mathrm{mg} 5$ 日間連続皮下注射した場合は第 7 日に於て $\mathrm{QO}_{2}$ は+13.4\%の増加, $\mathrm{QCO}_{2}$ は-7.7\%の低下を示すが第14日，第21日に於ては $\mathrm{QO}_{2}$ は略々前值に復し， $\mathrm{QCO}_{2}$ は第14日に-16.9\%の 低下学示すが第21日には略前值に戻る。一方網状赤血球数は第 7 日に $+134.8 \%$ の増加を示すが以後略々前

第11表 コーチゾン $2 \mathrm{mg} / \mathrm{kg} 5$ 日間投与群

\begin{tabular}{|c|c|c|c|c|c|c|c|c|c|}
\hline & 家鬼番号 & & 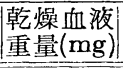 & $\mathrm{QO}_{2}$ & $\mathrm{QCO}_{2}$ & RQ & 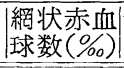 & $\begin{array}{l}\text { 赤血球数 } \\
\left(\times 10^{4}\right)\end{array}$ & $\begin{array}{c}\text { 血色素量 } \\
(\%)\end{array}$ \\
\hline \multirow{8}{*}{$\begin{array}{l}\text { 前 } \\
\text { 值 }\end{array}$} & No. 67 & 우 & 165.5 & 0.067 & 0.061 & 0.911 & 29 & 509 & 78 \\
\hline & 66 & $\hat{\delta}$ & 168.0 & 0.059 & 0.062 & 1.051 & 11 & 549 & 88 \\
\hline & 65 & $\hat{\jmath}$ & 192.0 & 0.064 & 0.057 & 0.891 & 14 & 553 & 80 \\
\hline & 64 & q & 167.5 & 0.062 & 0.064 & 1.032 & 23 & 540 & 85 \\
\hline & 52 & $\hat{\jmath}$ & 208.3 & 0.082 & 0.080 & 0.976 & 15 & 510 & 85 \\
\hline & 平均値 & & & 0.067 & 0.065 & 0.970 & 18.4 & 532.2 & 83.2 \\
\hline & 偏 差 & & & 0.009 & 0.009 & & 7.4 & 26.5 & 4.1 \\
\hline & 増減率 & & & 0 & 0 & & 0 & 0 & 0 \\
\hline \multirow{8}{*}{$\begin{array}{l}\text { 第 } \\
7 \\
\text { 日 }\end{array}$} & No. 67 & 우 & 170.0 & 0.065 & 0.058 & 0.892 & 36 & 462 & 78 \\
\hline & 66 & $\hat{o}$ & 164.8 & 0.057 & 0.043 & 0.754 & 46 & 500 & 84 \\
\hline & 65 & $\hat{o}$ & 187.8 & 0.078 & 0.061 & 0.782 & 37 & 498 & 80 \\
\hline & 64 & 우 & 187.5 & 0.089 & 0.063 & 0.701 & 50 & 472 & 84 \\
\hline & 52 & $\hat{\jmath}$ & 162.1 & 0.091 & 0.073 & 0.802 & 47 & 504 & 82 \\
\hline & 平均值 & & & 0.076 & 0.060 & 0.789 & 43.2 & 487.2 & 81.6 \\
\hline & 偏 差 & & & 0.015 & 0.011 & & 6.3 & 18.9 & 2.7 \\
\hline & 増減率 & & & +13.4 & -7.7 & & +134.8 & -8.5 & -1.9 \\
\hline \multirow{8}{*}{$\begin{array}{l}\text { 第 } \\
14 \\
\text { 日 }\end{array}$} & No. 67 & 우 & 207.3 & 0.079 & 0.057 & 0.722 & 19 & 472 & 80 \\
\hline & 66 & $\hat{\delta}$ & 183.0 & 0.060 & 0.052 & 0.867 & 12 & 535 & 85 \\
\hline & 65 & $\hat{\delta}$ & 166.0 & 0.071 & 0.054 & 0.761 & 16 & 485 & 78 \\
\hline & 64 & 우 & 196.0 & 0.062 & 0.043 & 0.693 & 21 & 510 & 80 \\
\hline & 52 & $\hat{\delta}$ & 161.0 & 0.080 & 0.062 & 0.775 & 20 & 507 & 80 \\
\hline & 平均值 & & & 0.070 & 0.054 & 0.771 & 17.6 & 501.8 & 80.6 \\
\hline & 偏 差 & & & 0.009 & 0.007 & & 3.6 & 23.4 & 2.7 \\
\hline & 増減率 & & & +4.5 & -16.9 & & -4.3 & -5.7 & -3.1 \\
\hline \multirow{8}{*}{$\begin{array}{l}\text { 第 } \\
\text { 日 } \\
\text { 日 }\end{array}$} & No. 67 & 우 & 165.3 & 0.070 & 0.056 & 0.800 & 25 & 492 & 85 \\
\hline & 66 & $\hat{\delta}$ & 174.0 & 0.059 & 0.056 & 0.950 & 23 & 549 & 85 \\
\hline & 65 & $\hat{\delta}$ & 163.5 & 0.072 & 0.067 & 0.931 & 19 & 471 & 80 \\
\hline & 64 & 우 & 195.5 & 0.067 & 0.058 & 0.860 & 21 & 522 & 80 \\
\hline & 52 & $\hat{\delta}$ & 176.7 & 0.070 & 0.054 & 0.914 & 24 & 517 & 80 \\
\hline & 平均値 & & & 0.068 & 0.061 & 0.897 & 22.4 & 510.2 & 82.0 \\
\hline & 偏 差 & & & 0.006 & 0.006 & & 2.5 & 30.8 & 2.8 \\
\hline & 增減率 & & & +1.5 & -6.2 & & +21.7 & -4.1 & -1.5 \\
\hline
\end{tabular}


第 9 図 コーチゾン $2 \mathrm{mg} / \mathrm{kg} 5$ 日間投与群

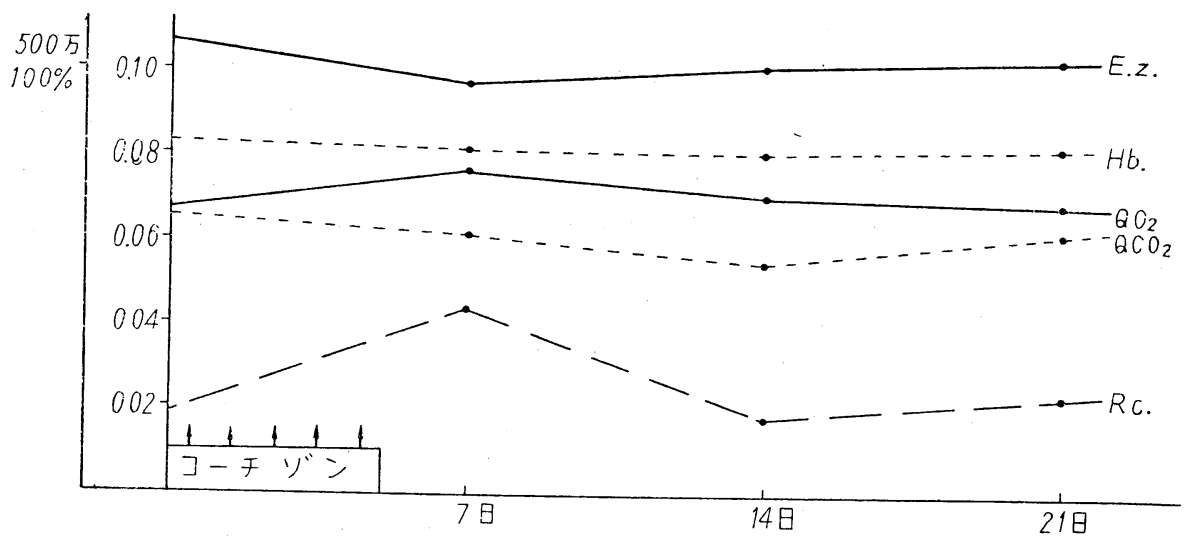

佰に厌る．赤血球数，血色素量は稍々低下傾向を示すが著明ではない．

\section{第 2 節 Desoxycorticosterone acetate 投与の影響}

副婜皮啠より分泌される mineralcorticoids 中 aldosterone の前階物質と考えられる desoxycorticosterone acetate（以下 DOGA と略）の連続投与により過ホルモン環境を生ぜしめ家鬼成熟赤血球呼吸に及ばす影㗽 を検索した. 即ち DOGA (Syncorta 武田薬品) を pro kopf $2.5 \mathrm{mg}$ 及び $1 \mathrm{mg}$ 各 5 日間連続投与を行つた.

(1) DOGA $2.5 \mathrm{mg} 5$ 日間連続投与による変動.

大量投与群として DOCA $2.5 \mathrm{mg}$ を 5 日間連続投与せる場合の成績を第 12 表及び第10図に示す.

第12表 DOCA $2.5 \mathrm{mg} / \mathrm{Kopf} 5$ 日閪投与群

\begin{tabular}{|c|c|c|c|c|c|c|c|c|c|}
\hline & \multicolumn{2}{|l|}{ |㑰琴潘㝍 } & 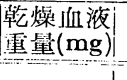 & $\mathrm{QO}_{2}$ & $\mathrm{QCO}_{3}$ & \multirow{2}{*}{$\frac{R Q}{1.030}$} & \multicolumn{2}{|c|}{ 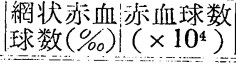 } & \multirow{2}{*}{$\begin{array}{c}\begin{array}{c}\text { If 色素量 } \\
(\%)\end{array} \\
82\end{array}$} \\
\hline \multirow{5}{*}{ 前 } & No. 50 & 우 & 187.0 & 0.069 & 0.071 & & 9 & 534 & \\
\hline & 49 & 우 & 203.0 & 0.068 & 0.066 & 0.971 & 21 & 490 & 77 \\
\hline & 48 & $\hat{\delta}$ & 186.8 & 0.072 & 0.074 & 1.028 & 5 & 552 & 85 \\
\hline & 47 & $\hat{\delta}$ & 160.0 & 0.067 & 0.066 & 0.985 & 21 & 535 & 80 \\
\hline & 46 & + & 162.0 & 0.083 & 0.080 & 0.964 & 20 & 552 & 85 \\
\hline \multirow[t]{4}{*}{ 値 } & 45 & 우 & 178.8 & 0.077 & 0.072 & 0.935 & 19 & 533 & 80 \\
\hline & 买均値 & & & 0.073 & 0.071 & 0.973 & 15.8 & 532.4 & 81.4 \\
\hline & 媹 差 & & & 0.006 & 0.006 & & 7.1 & 22.5 & 3.2 \\
\hline & 增娍溼 & & & 0 & 0 & & 0 & 0 & 0 \\
\hline \multirow{9}{*}{$\begin{array}{l}\text { 第 } \\
7 \\
\text { 日 }\end{array}$} & No. 50 & 우 & 200.0 & 0.050 & 0.023 & 0.460 & 111 & 445 & 78 \\
\hline & 49 & 우 & 180.0 & 0.063 & 0.020 & 0.318 & 120 & 407 & 70 \\
\hline & 48 & $\hat{\delta}$ & 172.3 & 0.059 & 0.024 & 0.407 & 78 & 428 & 73 \\
\hline & 47 & 令 & 169.0 & 0.076 & 0.031 & 0.408 & 102 & 472 & 80 \\
\hline & 46 & 우 & 206.0 & 0.060 & 0.021 & 0.350 & 55 & 429 & 79 \\
\hline & 45 & 우 & 191.0 & 0.047 & 0.015 & 0.319 & 110 & 364 & 80 \\
\hline & 平均值 & & & 0.059 & 0.022 & 0.373 & 96.0 & 424.2 & 76.7 \\
\hline & 偏 养 & & & 0.011 & 0.005 & & 22.6 & 36.8 & 4.2 \\
\hline & 增娍溹 & & & -19.2 & -69.0 & & +507.6 & -20.4 & -5.8 \\
\hline
\end{tabular}




\begin{tabular}{|c|c|c|c|c|c|c|c|c|c|}
\hline \multirow{9}{*}{$\begin{array}{l}\text { 第 } \\
14 \\
\text { 日 }\end{array}$} & No. 50 & 우 & 167.3 & 0.071 & 0.067 & 0.944 & 19 & 512 & 90 \\
\hline & 49 & 우 & 169.5 & 0.074 & 0.060 & 0.811 & 115 & 429 & 72 \\
\hline & 48 & $\hat{\delta}$ & 187.1 & 0.067 & 0.063 & 0.940 & 57 & 521 & 80 \\
\hline & 47 & $\hat{\jmath}$ & 153.0 & 0.075 & 0.056 & 0.747 & 74 & 531 & 84 \\
\hline & 46 & 우 & 187.0 & 0.060 & 0.049 & 0.817 & 21 & 461 & 80 \\
\hline & 45 & 우 & 181.5 & 0.077 & 0.072 & 0.935 & 48 & 478 & 80 \\
\hline & 平均値 & & & 0.071 & 0.061 & 0.859 & 55.7 & 488.7 & 81.0 \\
\hline & 偏 差 & & & 0.006 & 0.008 & & 38.9 & 38.8 & 5.9 \\
\hline & 増減率 & & & -2.7 & -14.1 & & +252.5 & -8.2 & -0.5 \\
\hline \multirow{9}{*}{$\begin{array}{l}\text { 第 } \\
\text { 日 } \\
\text { 日 }\end{array}$} & No. 50 & 우 & 191.0 & 0.065 & 0.059 & 0.908 & 24 & 499 & 80 \\
\hline & 49 & 우 & 221.0 & 0.068 & 0.054 & 0.794 & 23 & 531 & 83 \\
\hline & 48 & $\hat{\jmath}$ & 192.0 & 0.066 & 0.060 & 0.909 & 35 & 517 & 85 \\
\hline & 47 & $\hat{\delta}$ & 182.5 & 0.071 & 0.062 & 0.873 & 55 & 504 & 83 \\
\hline & 46 & 우 & 191.5 & 0.072 & 0.058 & 0.806 & 21 & 452 & 80 \\
\hline & 45 & 우 & 177.0 & 0.076 & 0.064 & 0.842 & 19 & 494 & 81 \\
\hline & 评均犆 & & & 0.070 & 0.060 & 0.857 & 29.5 & 499.5 & 82.0 \\
\hline & 偏 差 & & & 0.005 & 0.005 & & 13.7 & 34.2 & 2.0 \\
\hline & 増減率 & & & -4.1 & -15.5 & & +86.8 & -6.2 & +0.7 \\
\hline
\end{tabular}

第10図 DOCA $2.5 \mathrm{mg} / \mathrm{kopf} 5$ 日閻投与群

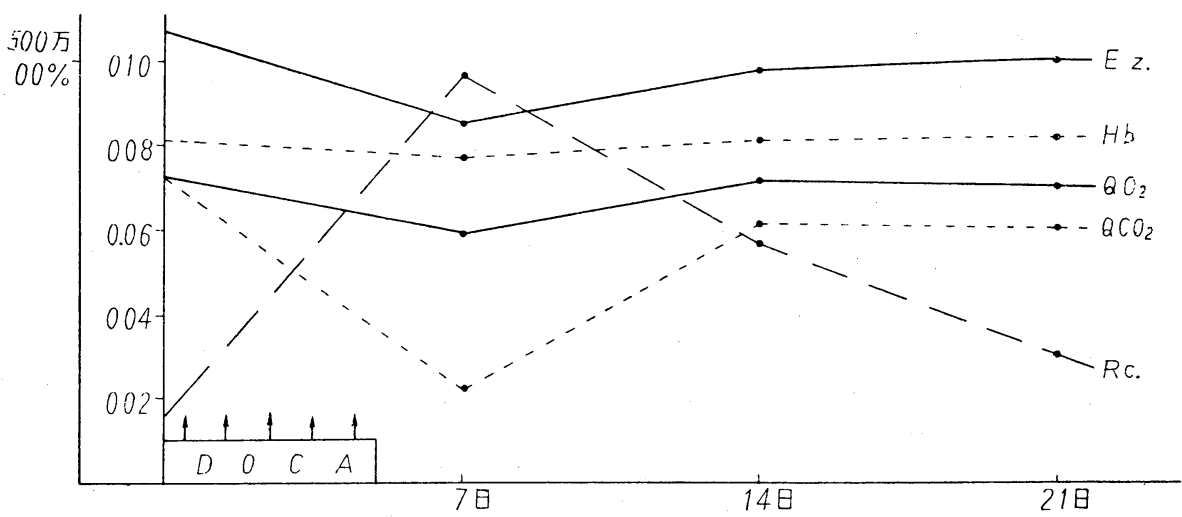

即ち DOGA $2.5 \mathrm{mg} 5$ 日間連続投与を行うと赤血球呼吸は第 7 日に於て著明に抑制せられ $\mathrm{QO}_{2}-19.2 \%$, $\mathrm{QCO}_{2}-69.0 \%$ の著減を示し特に $\mathrm{QCO}_{2}, \mathrm{RQ}$ の減少が著明である。第14日，第21日に於ては $\mathrm{QO}_{2}$ は略 前佔に復するが $\mathrm{QCO}_{2}$ は猶 $-14.1 \%,-15.5 \%$ の減少を認める. 一方網状赤血球数は第 7 日 $+507.6 \%$, 第 14 日 $+252.5 \%$ ，第 21 日 $+86.8 \%$ 著増を示すが赤血球数，血色素量は第 7 日に於て夫々 $-20.4 \% ，-5.8$ $\%$ \%減少を示したが之は体内水分貯溜による影響と認められる.

(2) DOCA $1 \mathrm{mg} 5$ 日間連続投与による变動

比較的少量投与群として DOCA $1 \mathrm{mg}$ を 5 日間連続投与せる場合の成績を第13表及び第11図に示す.

即ち DOCA $1 \mathrm{mg}$ 投与群に於ても前項 $2.5 \mathrm{mg}$ 投与群に於けると同様第 7 日に於て $\mathrm{QO}_{2}, \mathrm{QCO}_{2}$ は夫々 $-23.7 \% ，-26.5 \%$ の娍少を示し赤血球呼吸の抑制を見るが $\mathrm{QCO}_{2}, \mathrm{RQ}$ の減少は $2.5 \mathrm{mg}$ 投与群程著明で はない，第14日，第21日に於ては $\mathrm{QO}_{2}, \mathrm{QCO}_{2}$ 共略々前值に復している。一方網状赤血球数は第 7 日に於 
第13表 DOCAImg/Kopf 5 日間投与群

\begin{tabular}{|c|c|c|c|c|c|c|c|c|c|}
\hline & 家鬼番号 & & \begin{tabular}{|l|} 
乾燥血液 \\
重量(mg)
\end{tabular} & $\mathrm{QO}_{2}$ & $\mathrm{QCO}_{2}$ & $\mathrm{RQ}$ & $\left|\begin{array}{l}\mid \text { 網状赤血 } \\
\text { 球数 }(\% o)\end{array}\right|$ & $\begin{array}{l}\text { 赤血球数 } \\
\left(\times 10^{4}\right)\end{array}$ & $\begin{array}{c}\text { 血色素量 } \\
(\%)\end{array}$ \\
\hline \multirow{8}{*}{$\begin{array}{l}\text { 前 } \\
\text { 值 }\end{array}$} & No. 63 & 占 & 170.3 & 0.065 & 0.064 & 0.985 & 23 & 551 & 80 \\
\hline & 62 & 昘 & 207.0 & 0.089 & 0.065 & 0.731 & 11 & 587 & 82 \\
\hline & 61 & 令 & 191.0 & 0.060 & 0.063 & 1.050 & 6 & 588 & 90 \\
\hline & 60 & 우 & 166.0 & 0.083 & 0.071 & 0.856 & 14 & 504 & 84 \\
\hline & 59 & 우 & 194.7 & 0.081 & 0.076 & 0.939 & 16 & 545 & 80 \\
\hline & 平均值 & & & 0.076 & 0.063 & 0.895 & 14.0 & 555.0 & 83.2 \\
\hline & 偏 差 & & & 0.013 & 0.006 & & 6.3 & 34.5 & 4.9 \\
\hline & 増減率 & & & 0 & 0 & & 0 & 0 & 0 \\
\hline \multirow{8}{*}{$\begin{array}{c}\text { 第 } \\
7 \\
\text { 日 }\end{array}$} & No. 63 & $\hat{\jmath}$ & 176.2 & 0.058 & 0.048 & 0.828 & 17 & 526 & 90 \\
\hline & 62 & 令 & 180.4 & 0.064 & 0.061 & 0.953 & 19 & 473 & 80 \\
\hline & 61 & $ิ$ & 186.8 & 0.060 & 0.041 & 0.684 & 26 & 499 & 76 \\
\hline & 60 & 우 & 198.2 & 0.052 & 0.043 & 0.827 & 6 & 457 & 70 \\
\hline & 59 & 우 & 172.4 & 0.058 & 0.059 & 1.018 & 31 & 509 & 75 \\
\hline & 平均値 & & & 0.058 & 0.050 & 0.862 & 19.8 & 490.3 & 78.2 \\
\hline & 偏 差 & & & 0.006 & 0.009 & & 9.6 & 32.2 & 7.5 \\
\hline & 増減率 & & & -23.7 & -26.5 & & +41.4 & -11.6 & -6.1 \\
\hline \multirow{8}{*}{$\begin{array}{l}\text { 第 } \\
14 \\
\text { 日 }\end{array}$} & No. 63 & $\hat{\delta}$ & 200.0 & 0.066 & 0.046 & 0.697 & 54 & 533 & 83 \\
\hline & 62 & $\hat{\jmath}$ & 168.5 & 0.080 & 0.094 & 1.175 & 32 & 472 & 80 \\
\hline & 61 & $\hat{\delta}$ & 159.0 & 0.062 & 0.065 & 1.048 & 45 & 499 & 87 \\
\hline & 60 & 우 & 160.0 & 0.090 & 0.067 & 0.745 & 57 & 451 & 75 \\
\hline & 59 & 우 & 194.1 & 0.070 & 0.059 & 0.843 & 28 & 485 & 75 \\
\hline & 平均値 & & & 0.074 & 0.066 & 0.892 & 43.2 & 488.0 & 80.0 \\
\hline & 偏 差 & & & 0.012 & 0.006 & & 13.0 & 32.9 & 5.2 \\
\hline & 増減率 & & & -2.6 & -2.9 & & +208.6 & -12.1 & -3.8 \\
\hline \multirow{8}{*}{$\begin{array}{l}\text { 第 } \\
21 \\
\text { 日 }\end{array}$} & No. 63 & $\hat{\delta}$ & 188.0 & 0.072 & 0.064 & 0.889 & 36 & 510 & 90 \\
\hline & 62 & $\hat{\delta}$ & 182.5 & 0.074 & 0.072 & 0.973 & 38 & 497 & 82 \\
\hline & 61 & $\hat{\delta}$ & 158.0 & 0.067 & 0.061 & 0.910 & 42 & 528 & 88 \\
\hline & 60 & 우 & 179.0 & 0.078 & 0.077 & 0.988 & 21 & 506 & 80 \\
\hline & 59 & 우 & 201.0 & 0.057 & 0.058 & 1.019 & 36 & 499 & 80 \\
\hline & 平均值 & & & 0.070 & 0.067 & 0.949 & 34.6 & 508.0 & 84.0 \\
\hline & 偏 差 & & & 0.008 & 0.008 & & 8.0 & 39.2 & 5.5 \\
\hline & 増減率 & & & -7.9 & -1.5 & & +147.1 & -8.5 & +1.0 \\
\hline
\end{tabular}

ては赤血球数，血色素量が減少を示す割合に比し著明な増加を示さないが第14日，第21日に於ては夫々 $+208.6 \% ，+147.1 \%$ の増加を示している.

\section{第 3 節 副腎剔出の影響}

副腎剔出による実験的副腎皮質機能低下症の藏器組織呼吸に及㢳影響は種々報告されているが著者は赤 血球呼吸及び末梢血液像に及ぼす影響を検索した。即ち体重 $2.5 \mathrm{~kg} \sim 3 \mathrm{~kg}$ の成熟白色家鬼を用い先ず右副腎 剔出を行い手術侵襲による影響の恢復を待つて 第10日目に左副腎の剔出を行い以後 5 日間隔の測定を行つ た. 副腎剔出法は家鬼背腰部側方皮切開後, 背直筋腹筋間を鈍的に切開し腹膜に達し腎を確認したる後, 腎 
第11図 DOCA $1 \mathrm{mg} / \mathrm{kopf} 5$ 日間投与群

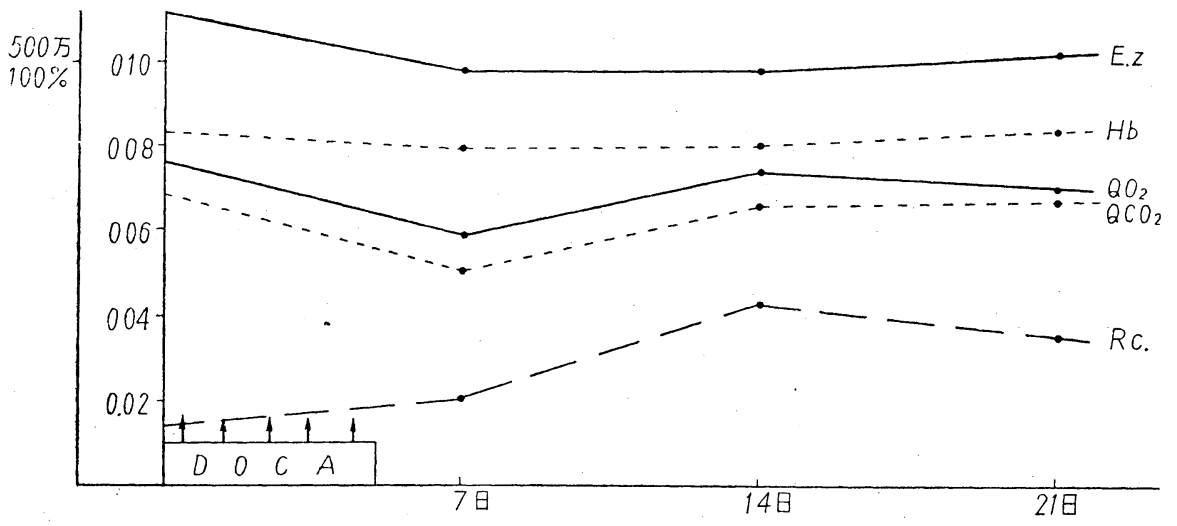

の後上方にある副腎に達し結禁切除する，右副腎は腹部大静脈壁の一部と共に結紮切除及び焼灼を行つた. 左副腎の剔出に際しては副副腎の存否を検索切除した。実験及び飼育は春季 $22^{\circ} \mathrm{C} \pm 2{ }^{\circ} \mathrm{C} の$ 室内にて行つた. 以上の方法による家鬼死亡率は右片側剔出後第 10 日目迄 $8.4 \%$, 両側剔出後第 5 日目迄 $41.6 \%$, 同第 10 日目 汽16.7\%で両側剔出後第10日に於て24匹中 8 匹（33.3\%）を実験に供し得た.

第14表 副筒副出対照群

\begin{tabular}{|c|c|c|c|c|c|c|c|c|c|}
\hline & 家鬼番号 & & $\mid$\begin{tabular}{|c}
$\mid$ 乾燥血液 \\
$\mid$ 重量(mg)
\end{tabular} & $\mathrm{QO}_{2}$ & $\mathrm{QCO}_{2}$ & $R Q$ & $\left|\begin{array}{l}\text { 網状赤血 } \\
\text { 球数 }(\%)\end{array}\right|$ & $\left|\begin{array}{l}\text { 赤血球数 } \\
\left(\times 10^{4}\right)\end{array}\right|$ & 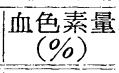 \\
\hline \multirow{7}{*}{$\begin{array}{l}\text { 片 } \\
\text { 側 } \\
\text { 手 } \\
\text { 術 } \\
\text { 後 } \\
\text { 第 } \\
5 \\
\text { 日 }\end{array}$} & No. 19 & 우 & 189.5 & 0.065 & 0.061 & 0.938 & 39 & 479 & 83 \\
\hline & 20 & $\hat{\jmath}$ & 181.5 & 0.076 & 0.071 & 0.934 & 42 & 507 & 80 \\
\hline & 21 & $\hat{\jmath}$ & 166.0 & 0.068 & 0.059 & 0.868 & 27 & 522 & 85 \\
\hline & 22 & 우 & 150.5 & 0.061 & 0.051 & 0.836 & 22 & 535 & 86 \\
\hline & 平均值 & & & 0.068 & 0.061 & 0.897 & 32.5 & 510.8 & 83.5 \\
\hline & 偏 差 & & & 0.007 & 0.008 & & 9.2 & 32.2 & 3.0 \\
\hline & 増減率 & & & -5.6 & -15.3 & & +92.3 & -4.9 & -0.4 \\
\hline \multirow{7}{*}{$\begin{array}{l}\text { 両 } \\
\text { 側 } \\
\text { 拳 } \\
\text { 術 } \\
\text { 後 } \\
\text { 第 } \\
5 \\
\text { 日 }\end{array}$} & No. 19 & 우 & 165.0 & 0.067 & 0.058 & 0.866 & 45 & 481 & 80 \\
\hline & 20 & $\hat{\jmath}$ & 207.5 & 0.063 & 0.047 & 0.746 & 102 & 468 & 75 \\
\hline & 21 & $\hat{\jmath}$ & 175.0 & 0.058 & 0.052 & 0.897 & 38 & 506 & 80 \\
\hline & 22 & 우 & 190.5 & 0.072 & 0.061 & 0.853 & 56 & 510 & 82 \\
\hline & 平均值 & & & 0.065 & 0.055 & 0.846 & 60.3 & 491.3 & 79.3 \\
\hline & 偏 差 & & & 0.006 & 0.006 & & 29.8 & 20.8 & 3.0 \\
\hline & 増減率 & & & -9.7 & -23.6 & & +256.8 & -8.5 & -5.4 \\
\hline \multirow{7}{*}{$\begin{array}{l}\text { 両 } \\
\text { 側 } \\
\text { 手 } \\
\text { 術 } \\
\text { 後 } \\
\text { 第 } \\
10 \\
\text { 日 }\end{array}$} & No. 19 & 우 & 173.0 & 0.064 & 0.052 & 0.812 & 77 & 462 & 75 \\
\hline & 20 & $\hat{\delta}$ & 191.0 & 0.071 & 0.065 & 0.916 & 68 & 438 & 77 \\
\hline & 21 & $\hat{\delta}$ & 155.5 & 0.061 & 0.051 & 0.836 & 80 & 490 & 78 \\
\hline & 22 & 우 & 180.0 & 0.057 & 0.036 & 0.632 & 43 & 487 & 76 \\
\hline & 平均值 & & & 0.063 & 0.051 & 0.809 & 67.0 & 469.3 & 76.5 \\
\hline & 偏 差 & & & 0.007 & 0.012 & & 16.8 & 24.4 & 1.5 \\
\hline & 増減率 & & & -12.5 & -29.2 & & +296.4 & -22.6 & -8.7 \\
\hline
\end{tabular}




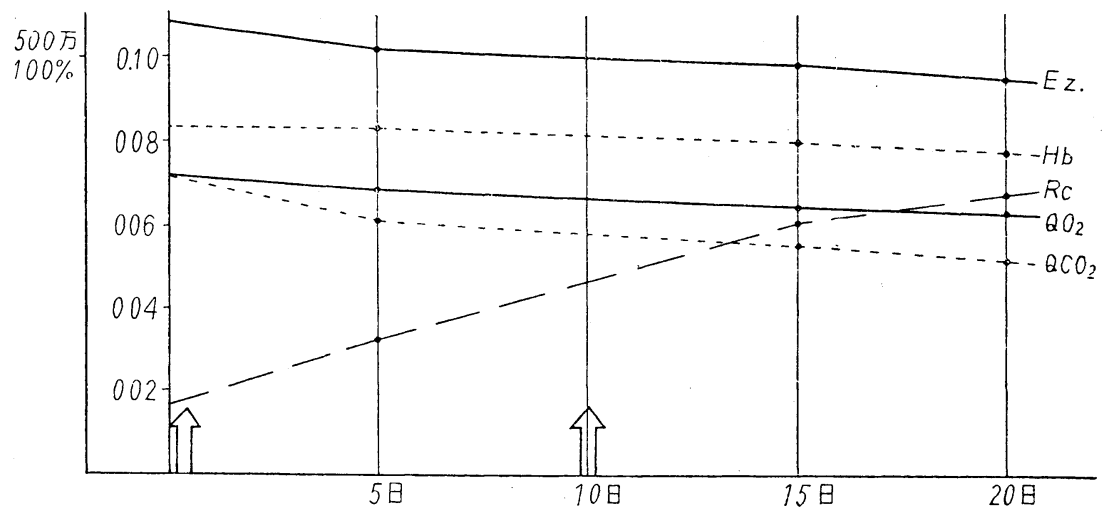

（1）副腎剔出対照手術による変勒

副腎剔出特手術侵襲の大なる為㑇手術群に於ける変動を観察した．之を第14表及び第12図に示す.

即ち 10 日間隔 2 回の副腎剔出偽手術により第 1 回手術後第 5 日に於て $\mathrm{QO}_{2}-5.6 \%, \mathrm{QCO}_{2}-15.3 \%$ の 減少を示すが網状赤血球は $+92.3 \%$ の増加を示す。第 2 回手術後第 5 日に於て $\mathrm{QO}_{2}-9.7 \%, \mathrm{QCO}_{2}-23.6$ $\%$ の減少，第10日に於て $\mathrm{QO}_{2}-12.5 \%, \mathrm{QCO}_{2}-29.2 \%$ の減少を示すが網状赤血球数は夫々 $+256.8 \%$,

第15表 副 腎 剔 出 群

\begin{tabular}{|c|c|c|c|c|c|c|c|c|c|}
\hline & 家乘番号 & & $\begin{array}{l}\text { 乾燥血液 } \\
\text { 重量 }(\mathrm{mg})\end{array}$ & $\mathrm{QO}_{2}$ & $\mathrm{QCO}_{2}$ & RQ & $\begin{array}{l}\text { 緍状赤血 } \\
\text { 球数 }(\%)\end{array}$ & $\begin{array}{l}\text { 赤血球数 } \\
\left(\times 10^{4}\right)\end{array}$ & $\begin{array}{c}\text { 血色系量 } \\
(\%)\end{array}$ \\
\hline \multirow{11}{*}{$\begin{array}{c}\text { 右 } \\
\text { 非 } \\
\text { 則 } \\
\text { 剔 } \\
\text { 出 } \\
\text { 後 } \\
\text { 第 } \\
5 \\
\text { 日 }\end{array}$} & No. 111 & $\hat{\delta}$ & 165.5 & 0.060 & 0.065 & 1.083 & 57 & 507 & 82 \\
\hline & 114 & $\hat{\delta}$ & 172.0 & 0.072 & 0.071 & 0.986 & 30 & 474 & 78 \\
\hline & 117 & $\hat{\delta}$ & 200.0 & 0.073 & 0.066 & 0.904 & 110 & 447 & 74 \\
\hline & 122 & $\uparrow$ & 190.5 & 0.078 & 0.073 & 0.936 & 13 & 520 & 85 \\
\hline & 128 & 우 & 168.0 & 0.072 & 0.057 & 0.792 & 52 & 444 & 78 \\
\hline & 129 & 우 & 207.0 & 0.063 & 0.052 & 0.825 & 41 & 458 & 76 \\
\hline & 131 & 우 & 171.5 & 0.071 & 0.061 & 0.859 & 52 & 477 & 78 \\
\hline & 133 & $\hat{\delta}$ & 152.6 & 0.067 & 0.046 & 0.687 & 40 & 501 & 80 \\
\hline & 水均值 & & & 0.070 & 0.061 & 0.883 & 49.4 & 478.5 & 78.9 \\
\hline & 酮 差 & & & 0.006 & 0.009 & & 28.4 & 28.5 & 3.5 \\
\hline & 増減率 & & & -2.8 & -15.3 & & +192.3 & -10.9 & -5.8 \\
\hline \multirow{11}{*}{$\begin{array}{l}\text { 雨 } \\
\text { 則 } \\
\text { 剔 } \\
\text { 出 } \\
\text { 後 } \\
\text { 第 } \\
5 \\
\text { 日 }\end{array}$} & No. 111 & $\hat{\delta}$ & 191.0 & 0.050 & 0.037 & 0.740 & 32 & 538 & 85 \\
\hline & 114 & $\hat{\delta}$ & 177.5 & 0.061 & 0.048 & 0.787 & 48 & 486 & 75 \\
\hline & 117 & 占 & 181.1 & 0.057 & 0.051 & 0.895 & 74 & 495 & 80 \\
\hline & 122 & $\hat{\delta}$ & 162.0 & 0.043 & 0.039 & 0.907 & 26 & 574 & 90 \\
\hline & 128 & 우 & 195.3 & 0.059 & 0.050 & 0.848 & 61 & 506 & 78 \\
\hline & 129 & 우 & 170.3 & 0.054 & 0.033 & 0.611 & 56 & 557 & 82 \\
\hline & 131 & 우 & 160.5 & 0.048 & 0.036 & 0.750 & 80 & 488 & 77 \\
\hline & 133 & $\hat{o}$ & 203.0 & 0.045 & 0.04 .1 & 0.911 & 31 & 516 & 85 \\
\hline & 站均值 & & & 0.052 & 0.042 & 0.808 & 51.0 & 520.0 & 81.5 \\
\hline & 偏 差 & & & 0.006 & 0.007 & & 20.2 & 37.7 & 5.0 \\
\hline & 増娍率 & & & -27.8 & -41.7 & & +201.8 & -3.1 & -2.7 \\
\hline
\end{tabular}




\begin{tabular}{|c|c|c|c|c|c|c|c|c|c|}
\hline \multirow{11}{*}{$\begin{array}{l}\text { 両 } \\
\text { 側 } \\
\text { 剔 } \\
\text { 出 } \\
\text { 後 } \\
\text { 第 } \\
10 \\
\text { 日 }\end{array}$} & No. 111 & $\hat{\delta}$ & 182.0 & 0.038 & 0.027 & 0.711 & 22 & 583 & 88 \\
\hline & 114 & $\hat{\delta}$ & 165.0 & 0.052 & 0.035 & 0.673 & 30 & 547 & 83 \\
\hline & 117 & $\hat{\delta}$ & 197.0 & 0.040 & 0.030 & 0.750 & 61 & 515 & 85 \\
\hline & 122 & $\hat{\delta}$ & 215.0 & 0.032 & 0.028 & 0.875 & 22 & 608 & 92 \\
\hline & 128 & 우 & 171.0 & 0.027 & 0.031 & 1.149 & 28 & 562 & 86 \\
\hline & 129 & 우 & 203.5 & 0.044 & 0.036 & 0.818 & 51 & 584 & 85 \\
\hline & 131 & 우 & 207.5 & 0.035 & 0.027 & 0.771 & 63 & 508 & 80 \\
\hline & 133 & 占 & 181.5 & 0.039 & 0.033 & 0.846 & 11 & 591 & 90 \\
\hline & 平均值 & & & 0.038 & 0.031 & 0.816 & 36.0 & 562.3 & 86.0 \\
\hline & 偏 差 & & & 0.008 & 0.005 & & 19.9 & 34.6 & 4.5 \\
\hline & 增減率 & & & -47.2 & -56.9 & & +83.7 & +4.7 & +2.6 \\
\hline
\end{tabular}

第13図 副腎剔出群

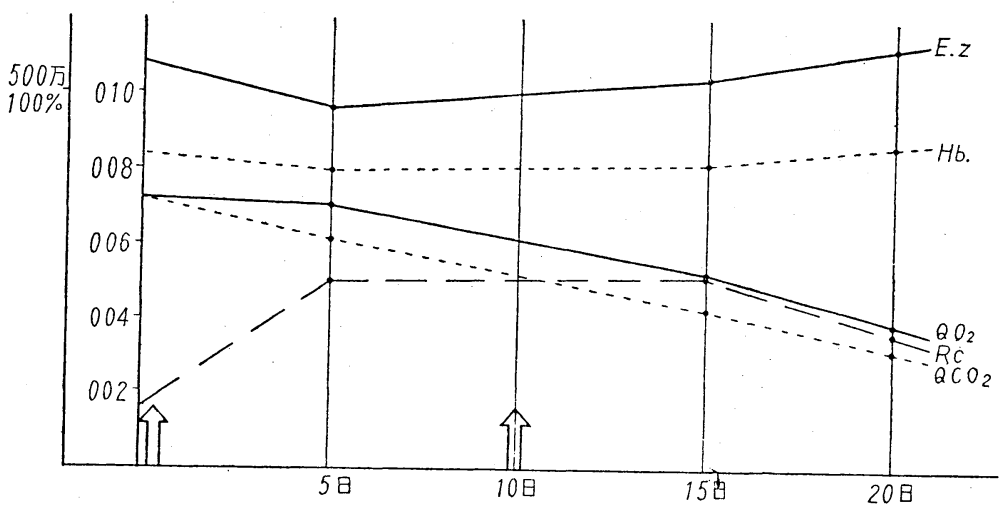

$+296.4 \%$ の増加を示した。 この間赤血球数及び血色素量は渐減を示した。即ち10日間隔 2 回の偽手術侵襲 により赤血球呼吸は網状赤血球数の増加沟拘らず渐娍导る。

（2）副腎别出に上る変動

既述の方法により家鬼副腎を二次的に全剔せる場合の赤血球呼吸及び末梢血液像の变動を第 15 表及び第 13 戝示す。

即ち右片側剔出後第 5 日に於て $\mathrm{QO}_{2}$ は著变を見ないが $\mathrm{QCO}_{2}$ は $15.3 \%$ の減少を示す．網状赤血球数は $+192.3 \%$ の増加を示し赤血球数，血色素量は诚少する。之弓の変動は刘照偽手術群に比較して著差を見な い. 次に左側副腎を剔出すると術後第 5 日に於て $\mathrm{QO}_{2}-27.8 \%, \mathrm{QCO}_{2}-41.7 \%$ 第10日には $\mathrm{QO}_{2}-47.2 \%$, $\mathrm{QCO}_{2}-56.9 \%$ の著減を示す. 網状赤血球数は夫々 $+201.8 \%,+83.7 \%$ の増加を示す.一方赤血球数, 血 色素量は雨側剔出後増加傾向を示す。両側副珡剔出家秘の著明な体重減少より之は血液濃縮によるもの之思 われる，以上より副婜剔出により赤血球呼吸は片側剔出では対照に比し著差を見ないが両側剔出後は著明な 呼吸係数の低下を認める.

\section{第 4 節副腎皮質ホルモン試験管内添加による影響}

副腎皮㑭ホルモンの組織酸素消費量に及ぼす直接作用に関しては幾多の報告を見る所であるか臟器の種 類, 添加ホルモン濃度, 時間経過, 浮游液の電解質の量と質, 使用動物の状驡, 組織量等により影響される 所が大であつて報告成績も一定傾向を見ないものが多い，かかる点より成熱赤血球の僅微な呼吸に及ぼす steroidhormone の直接作用の梌討には一定条件の設定が必要であるが著者は既述方法により cortisone 
acetate 及び desoxycorticosterone glucoside (DOGG 之略, cortiron, Schelling) を用い in vitro 亿於け る赤血球呼吸に及ぼす影響を検討した。 その成績を第16表及び第17表に示す.

即ち cortisone acetate を $1 \mathrm{cc}$ 中各 $0.25 \gamma, 2.5 \gamma, 25 \gamma$ 含有せる赤血球浮游液の $\mathrm{QO}_{2}, \mathrm{QCO}_{2}$ は対照に比 し有意の增减を示さず，又 DOCG を $1 \mathrm{cc}$ 中各 $0.5 \gamma, 5 \gamma, 50 \gamma$ 添加した場合も対照に比し有意の増減に示 さなかつた。

\section{第 5 節 本章小括}

赤血球呼吸及び未梢血腹像に及ぼす副等皮質機能の影響を以上の実験成績より要約すると以下の如くであ る.

即ち cortisone pro $\mathrm{kg} 5 \mathrm{mg}$ 及び $2 \mathrm{mg}$ の連続投与による過ホルモン環境に於ては赤血球呼吸の充進を認 めるがその増堿経過は投与量により異り pro kg $5 \mathrm{mg}$ の大量投与では初め $\mathrm{QCO}_{2}$ の減少が著明であり蜜 万赤血球呼吸の抑制傾向をみるが次で $\mathrm{QO}_{2}$ の増加を来すが pro $\mathrm{kg} 2 \mathrm{mg}$ の比較的少量投与では初期より $\mathrm{QO}_{2}$ の上昇を認める. 未梢血淮像も大量投与では網状赤血球数の増加，赤血球数の減少が著明であるが少 量投与では前者程著明ではなかつた。

DOC 系 steroidhormone の酸化代謝抑制作用に就ては種々報告をみる所であるが著者は DOCA 㕝

第16表 コーチゾン試験管内添加実験

\begin{tabular}{|c|c|c|c|c|c|c|}
\hline $\begin{array}{c}コ \text { エチゾン } \\
\text { 添加量 }\end{array}$ & 家鬼番号 & & 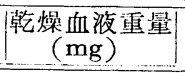 & $\mathrm{QO}_{2}$ & $\mathrm{QCO}_{2}$ & RQ \\
\hline \multirow{5}{*}{ 対照 } & No. 1 & $\hat{\delta}$ & 182.5 & 0.061 & 0.065 & 1.066 \\
\hline & 2 & $\hat{o}$ & 175.5 & 0.069 & 0.082 & 1.188 \\
\hline & 3 & 우 & 198.0 & 0.067 & 0.058 & 0.866 \\
\hline & 5 & 우 & 165.0 & 0.075 & 0.085 & 1.133 \\
\hline & 7 & $\hat{o}$ & 201.0 & 50.68 & 0.063 & 0.927 \\
\hline 平均值 & & & & 0.068 & 0.071 & 1.038 \\
\hline \multirow{5}{*}{$0.25 \gamma / \mathrm{cc}$} & No. 1 & $\uparrow$ & 207.0 & 0.064 & 0.062 & 0.969 \\
\hline & 2 & $\hat{o}$ & 176.5 & 0.073 & 0.070 & 0.959 \\
\hline & 3 & 우 & 170.5 & 0.063 & 0.065 & 1.032 \\
\hline & 5 & 우 & 191.2 & 0.076 & 0.073 & 0.961 \\
\hline & 7 & $\hat{\delta}$ & 185.0 & 0.069 & 0.068 & 0.986 \\
\hline 平均值 & & & & 0.069 & 0.068 & 0.980 \\
\hline \multirow{5}{*}{$2.5 \gamma / \mathrm{cc}$} & No. 1 & $\hat{\delta}$ & 165.2 & 0.072 & 0.069 & 0.959 \\
\hline & 2 & $\hat{\delta}$ & 185.5 & 0.065 & 0.071 & 1.092 \\
\hline & 3 & 우 & 210.5 & 0.063 & 0.058 & 0.921 \\
\hline & 5 & 우 & 192.0 & 0.081 & 0.067 & 0.827 \\
\hline & 7 & $\hat{o}$ & 178.5 & 0.067 & 0.072 & 1.075 \\
\hline 平均値 & & & & 0.070 & 0.067 & 0.968 \\
\hline \multirow{5}{*}{$25 \gamma / \mathrm{cc}$} & No. 1 & $\hat{\delta}$ & 185.0 & 0.067 & 0.067 & 1.000 \\
\hline & 2 & $\hat{o}$ & 165.0 & 0.074 & 0.080 & 1.081 \\
\hline & 3 & 우 & 167.5 & 0.080 & 0.071 & 0.889 \\
\hline & 5 & 우 & 193.3 & 0.063 & 0.068 & 1.079 \\
\hline & 7 & $\hat{\jmath}$ & 175.5 & 0.077 & 0.072 & 0.935 \\
\hline 平均值 & & & & 0.072 & 0.072 & 0.992 \\
\hline
\end{tabular}


第17表 DOGG 試験管内添加実験

\begin{tabular}{|c|c|c|c|c|c|c|}
\hline $\begin{array}{c}\text { DOCG } \\
\text { 添加量 } \\
\end{array}$ & 家鬼番号 & & 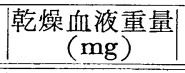 & $\mathrm{QO}_{2}$ & $\mathrm{QCO}_{2}$ & RQ \\
\hline \multirow{5}{*}{ 対照 } & No. 8 & 우 & 189.2 & 0.068 & 0.071 & 1.044 \\
\hline & 9 & $\hat{\delta}$ & 200.5 & 0.073 & 0.068 & 0.931 \\
\hline & 10 & $\hat{\delta}$ & 167.0 & 0.081 & 0.070 & 0.864 \\
\hline & 11 & $\hat{\delta}$ & 193.0 & 0.063 & 0.065 & 1.032 \\
\hline & 12 & 우 & 177.5 & 0.061 & 0.059 & 0.967 \\
\hline \multirow[t]{3}{*}{ 平均值 } & & & & 0.069 & 0.067 & 0.962 \\
\hline & No. 8 & 우 & 176.5 & 0.065 & 0.062 & 0.954 \\
\hline & 9 & $\hat{\delta}$ & 191.0 & 0.074 & 0.064 & 0.865 \\
\hline \multirow[t]{3}{*}{$0.5 \gamma / \mathrm{cc}$} & 10 & $\hat{o}$ & 186.5 & 0.073 & 0.071 & 0.973 \\
\hline & 11 & $\hat{\delta}$ & 153.6 & 0.061 & 0.068 & 1.115 \\
\hline & 12 & ㅇ & 171.5 & 0.069 & 0.059 & 0.885 \\
\hline 平均值 & & & & 0.068 & 0.065 & 0.947 \\
\hline \multirow{5}{*}{$5 \gamma / \mathrm{cc}$} & No. 8 & 우 & 180.0 & 0.058 & 0.054 & 0.931 \\
\hline & 9 & $\hat{\delta}$ & 165.3 & 0.072 & 0.062 & 0.861 \\
\hline & 10 & $\hat{\delta}$ & 192.2 & 0.065 & 0.068 & 1.046 \\
\hline & 11 & $\hat{o}$ & 195.0 & 0.073 & 0.065 & 0.890 \\
\hline & 12 & 우 & 163.0 & 0.060 & 0.066 & 1.100 \\
\hline 平均值 & & & & 0.066 & 0.063 & 0.960 \\
\hline \multirow{5}{*}{$50 \gamma / \mathrm{cc}$} & No. 8 & 오 & 185.5 & 0.062 & 0.055 & 0.887 \\
\hline & 9 & $\hat{\delta}$ & 205.0 & 0.071 & 0.062 & 0.873 \\
\hline & 10 & 令 & 178.5 & 0.080 & 0.073 & 0.901 \\
\hline & 11 & $\hat{\delta}$ & 191.5 & 0.072 & 0.064 & 0.889 \\
\hline & 12 & 우 & 165.0 & 0.064 & 0.065 & 1.016 \\
\hline 平均値 & & & & 0.070 & 0.064 & 0.914 \\
\hline
\end{tabular}

$2.5 \mathrm{mg}$ 及び $1 \mathrm{mg}$ 連続投与し赤血球呼吸に及ぼす影響を検索した。即ち DOCA により赤血球呼吸は著明 に抑制されるえ゙殊に大量投与により $\mathrm{QCO}_{2}, \mathrm{RQ}$ の低下が著明であつた。一方 DOGA 投与による網状赤血 球数の変動は投与量により異り大量投与により著明な増加を示し又体内水分貯溜による赤血球数, 血色素量 の減少をみるが少量投与では網状赤血球数は著増を示さず渻乃造血機能の抑制傾向を示し赤血球数，血色素 量の減少も著明ではなかつた。

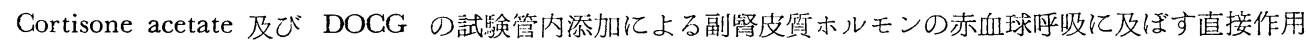
隹衿め得なかつた。

副腎剔出による基礎代謝，酸化代謝の変化は主として glucocorticoids によるものである事が認められて

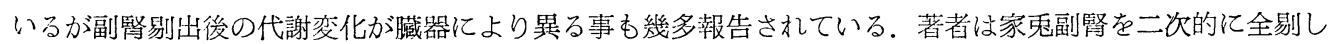
副骳皮質機能低下症を起さしもた場合家鬼成熟赤血球の呼吸係数は手術対照群に比し著明な低下を示す事在 証好た。

以上より副腎皮質機能が造血藏器と共に赤血球呼吸に種々の影響を与える事を認めた。

\section{第五章 性腺機能と赤血球呼吸}


近時性ホルモンの性器外作用が注目され蛋白質, 糖質, 脂質等の代謝に及ぼす影響が広く検索されて居 る. 酸化代謝们関する研究報告も多数みられ，而して斯る somatic growth に対する促進作用は androgen に於て著明であり estrogen はむしろ抑制的に作用するとされている。一方造血機能に及ぼす影響む種々冁 告されているが赤血球呼吸に及ぼす性腺機能の影響に関しては知見に乏しい. 著者は以上の事実より性ホル モン投与及び性腺剔出の赤血球呼吸及び末梢血液像に及ばす影響を検索せんとして以下の実験を行つた。

第 1 節 Testosterone propionate 投与の影響

男性ホルモンとして testosterone propionate (以下 T.P.と略す， Enarmon 帝国臟器製）を $1 \mathrm{mg} 5$

第18表 焳性家鬼に対守る T.P.1mg/Kopf 5 日閭投与実験

\begin{tabular}{|c|c|c|c|c|c|c|c|c|c|}
\hline & 家鬼番号 & & $\begin{array}{l}\text { 乾燥血液 } \\
\text { 重量 }(\mathrm{mg}) \\
\end{array}$ & $\mathrm{QO}_{2}$ & $\mathrm{QCO}_{2}$ & $\mathrm{RO}$ & $\begin{array}{l}\text { 縚状赤血 } \\
\text { 球数 }(\%)\end{array}$ & $\begin{array}{c}\text { 赤血球数 } \\
\left(\times 10^{4}\right)\end{array}$ & $\begin{array}{c}\text { 血色素量 } \\
(\%)\end{array}$ \\
\hline \multirow{8}{*}{$\begin{array}{l}\text { 前 } \\
\text { 值 }\end{array}$} & No. 78 & $\hat{\delta}$ & 174.7 & 0.073 & 0.080 & 1.096 & 19 & 558 & 85 \\
\hline & 72 & $\hat{\delta}$ & 206.3 & 0.073 & 0.084 & 1.151 & 23 & 554 & 85 \\
\hline & 39 & $\hat{\delta}$ & 187.0 & 0.070 & 0.072 & 1.029 & 15 & 537 & 80 \\
\hline & 38 & $\hat{\delta}$ & 158.0 & 0.063 & 0.068 & 1.079 & 22 & 509 & 80 \\
\hline & 35 & $\hat{o}$ & 165.3 & 0.077 & 0.073 & 0.948 & 8 & 512 & 85 \\
\hline & 平均值 & & & 0.071 & 0.075 & 1.056 & 17.4 & 534.0 & 83.0 \\
\hline & 偏 差 & & & 0.006 & 0.006 & & 6.2 & 22.9 & 2.1 \\
\hline & 増減率 & & & 0 & 0 & & 0 & 0 & 0 \\
\hline \multirow{8}{*}{$\begin{array}{l}\text { 第 } \\
7 \\
\text { 日 }\end{array}$} & No. 78 & $\hat{o}$ & 181.5 & 0.089 & 0.069 & 0.775 & 79 & 489 & 77 \\
\hline & 72 & $\hat{o}$ & 202.5 & 0.090 & 0.065 & 0.723 & 87 & 481 & 75 \\
\hline & 39 & $\hat{o}$ & 172.0 & 0.092 & 0.071 & 0.772 & 52 & 507 & 85 \\
\hline & 38 & $\hat{\delta}$ & 167.3 & 0.076 & 0.064 & 0.842 & 91 & 512 & 80 \\
\hline & 35 & $\hat{o}$ & 154.5 & 0.084 & 0.074 & 0.881 & 82 & 478 & 80 \\
\hline & 平均值 & & & 0.086 & 0.069 & 0.803 & 78.2 & 493.4 & 79.4 \\
\hline & 偏 差 & & & 0.007 & 0.005 & & 15.5 & 15.7 & 3.8 \\
\hline & 堌減率 & & & +21.1 & -8.0 & & +349.4 & -7.6 & -4.3 \\
\hline \multirow{8}{*}{$\begin{array}{l}\text { 第 } \\
14 \\
\text { 日 }\end{array}$} & No. 78 & 令 & 172.5 & 0.066 & 0.053 & 0.803 & 31 & 525 & 84 \\
\hline & 72 & $\hat{\delta}$ & 202.5 & 0.089 & 0.062 & 0.696 & 56 & 487 & 85 \\
\hline & 39 & $\hat{\delta}$ & 187.7 & 0.073 & 0.063 & 0.863 & 27 & 520 & 85 \\
\hline & 38 & $\hat{\delta}$ & 160.0 & 0.077 & 0.065 & 0.844 & 72 & 483 & 78 \\
\hline & 35 & $\hat{o}$ & 192.5 & 0.075 & 0.062 & 0.827 & 47 & 465 & 75 \\
\hline & 平均颠 & & & 0.076 & 0.061 & 0.803 & 46.6 & 496.0 & 81.4 \\
\hline & 偏 差 & & & 0.008 & 0.005 & & 18.5 & 27.0 & 4.7 \\
\hline & 增減率 & & & +7.1 & -18.7 & & +167.8 & -7.1 & -1.9 \\
\hline \multirow{8}{*}{$\begin{array}{l}\text { 第 } \\
21 \\
\text { 日 }\end{array}$} & No. 78 & $\hat{\delta}$ & 177.5 & 0.077 & 0.080 & 1.039 & 7 & 540 & 83 \\
\hline & 72 & $\hat{\delta}$ & 198.8 & 0.063 & 0.058 & 0.921 & 3 & 497 & 80 \\
\hline & 39 & $\hat{\jmath}$ & 157.5 & 0.073 & 0.070 & 0.959 & 14 & 515 & 80 \\
\hline & 38 & $\hat{o}$ & 171.0 & 0.076 & 0.068 & 0.895 & 18 & 501 & 83 \\
\hline & 35 & $\hat{\delta}$ & 172.3 & 0.070 & 0.067 & 0.957 & 19 & 478 & 84 \\
\hline & 平均值 & & & 0.072 & 0.069 & 0.959 & 12.2 & 506.2 & 82.0 \\
\hline & 倔 差 & & & 0.006 & 0.008 & & 5.7 & 25.4 & 3.3 \\
\hline & 増減率 & & & +1.4 & -8.0 & & -29.9 & -5.2 & -1.2 \\
\hline
\end{tabular}


第14図 雄性家鬼に対する T.P.1 mg/kopf 5 日間投与実験

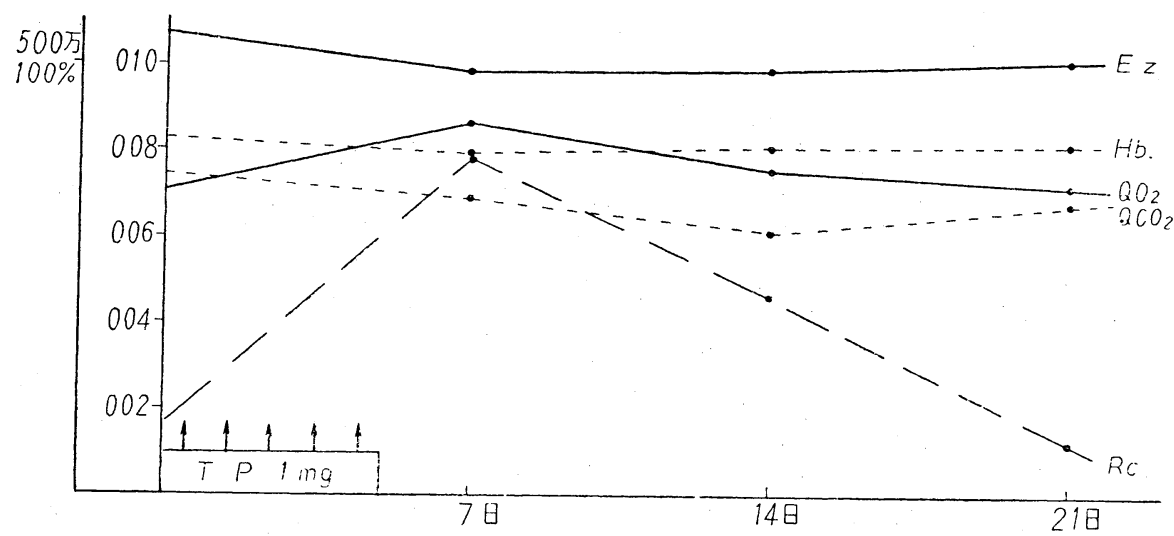

日間連続皮下注射して過ホルモン環境を生ぜしめその赤血球呼吸及び末梢血液像に及ぼす影響を検索した。 实験は雄性群及び倠性群に分つて行つた。

(1) 雄性家鬼に対するT.P.1 mg連続投与.の影響

雄家鬼に対するT．P．1 mg 5 日間連続投与による赤血球呼吸及び末梢血液像の变動は第18表及び第14図 に示す如くである。

即ち T.P. $1 \mathrm{mg}$ 連続投与により第 7 日亿於て $\mathrm{QO}_{2}+21.1 \%, \mathrm{QCO}_{2}-8.0 \%$ の増隇を示すが網状赤血球 数む $+349.4 \%$ の著増を示す。第 14 日に於ては $\mathrm{QO}_{2}+7.1 \%, \mathrm{QCO}_{2}-18.7 \%$ の増減を示し $\mathrm{QCO}_{2}$ の減少 莟認めるが第21日に於ては前值への恢復傾向を示した。

(2) 雌性家鬼に対するT.P. $1 \mathrm{mg}$ 連続投与の影響

第19表 雌性家鬼化対与る T.P.1mg/Kopf 5 日間投与実験

\begin{tabular}{|c|c|c|c|c|c|c|c|c|c|}
\hline & 家息潘䒓 & & $\begin{array}{l}\text { 活㫵血液 } \\
\text { 重量(mg) }\end{array}$ & $\mathrm{QO}_{2}$ & $\mathrm{QCO}_{2}$ & $R Q$ & 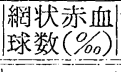 & $\begin{array}{l}\text { 赤血球数 } \\
\left(\times 10^{4}\right)\end{array}$ & $\begin{array}{c}\text { 血色素量 } \\
(\%)\end{array}$ \\
\hline \multirow{8}{*}{$\begin{array}{l}\text { 前 } \\
\text { 值 }\end{array}$} & No. 55 & 우 & 157.0 & 0.100 & 0.082 & 0.820 & 21 & 586 & 93 \\
\hline & 54 & 우 & 186.5 & 0.061 & 0.052 & 0.853 & 22 & 520 & 80 \\
\hline & 53 & 早 & 204.5 & 0.061 & 0.068 & 1.115 & 7 & 505 & 80 \\
\hline & 37 & 우 & 171.0 & 0.075 & 0.072 & 0.950 & 14 & 524 & 85 \\
\hline & 36 & 우 & 189.3 & 0.073 & 0.073 & 1.000 & 16 & 530 & 83 \\
\hline & 平均值 & & & 0.074 & 0.070 & 0.946 & 16.0 & 533.0 & 84.2 \\
\hline & 俯 差 & & & 0.006 & 0.005 & & 6.1 & 32.3 & 5.4 \\
\hline & 増減率 & & & 0 & 0 & & 0 & 0 & 0 \\
\hline \multirow{8}{*}{$\begin{array}{c}\text { 第 } \\
7 \\
\text { 日 }\end{array}$} & No. 55 & 우 & 186.0 & 0.083 & 0.071 & 0.855 & 98 & 509 & 83 \\
\hline & 54 & 우 & 169.6 & 0.070 & 0.061 & 0.871 & 64 & 472 & 78 \\
\hline & 53 & 우 & 176.0 & 0.075 & 0.064 & 0.853 & 16 & 500 & 80 \\
\hline & 37 & 우 & 186.6 & 0.067 & 0.058 & 0.866 & 82 & 473 & 80 \\
\hline & 36 & 우 & 173.0 & 0.078 & 0.067 & 0.860 & 57 & 512 & 85 \\
\hline & 平均值 & & & 0.075 & 0.064 & 0.853 & 63.0 & 493.2 & 81.2 \\
\hline & 偏 差 & & & 0.006 & 0.005 & & 31.4 & 19.7 & 2.8 \\
\hline & 增娍㨇 & & & +1.4 & -8.6 & & +293.8 & -7.5 & -3.6 \\
\hline
\end{tabular}




\begin{tabular}{|c|c|c|c|c|c|c|c|c|c|}
\hline \multirow{8}{*}{$\begin{array}{l}\text { 第 } \\
14 \\
\text { 日 }\end{array}$} & No. 55 & 우 & 165.3 & 0.068 & 0.065 & 0.956 & 67 & 507 & 84 \\
\hline & 54 & 우 & 177.5 & 0.075 & 0.062 & 0.827 & 90 & 511 & 85 \\
\hline & 53 & 우 & 195.0 & 0.068 & 0.059 & 0.868 & 25 & 453 & 76 \\
\hline & 37 & 우 & 177.1 & 0.060 & 0.053 & 0.883 & 73 & 507 & 80 \\
\hline & 36 & 우 & 210.5 & 0.075 & 0.063 & 0.840 & 43 & 495 & 78 \\
\hline & 平均値 & & & 0.069 & 0.060 & 0.870 & 59.6 & 494.6 & 80.6 \\
\hline & 偏 差 & & & 0.006 & 0.004 & & 25.7 & 24.2 & 3.9 \\
\hline & 増減率 & & & -6.8 & -14.3 & & +272.5 & -7.2 & -4.3 \\
\hline \multirow{8}{*}{$\begin{array}{l}\text { 第 } \\
\text { 日 }\end{array}$} & No. 55 & 우 & 184.3 & 0.074 & 0.067 & 0.905 & 34 & 549 & 90 \\
\hline & 54 & 우 & 207.0 & 0.066 & 0.065 & 0.985 & 21 & 554 & 90 \\
\hline & 53 & 우 & 165.7 & 0.072 & 0.078 & 1.083 & 25 & 528 & 85 \\
\hline & 37 & 우 & 171.0 & 0.064 & 0.061 & 0.953 & 32 & 522 & 83 \\
\hline & 36 & 우 & 194.0 & 0.082 & 0.073 & 0.890 & 23 & 510 & 85 \\
\hline & 平均值 & & & 0.072 & 0.069 & 0.958 & 27.0 & 532.6 & 86.6 \\
\hline & 偏 差 & & & 0.006 & 0.005 & & 5.7 & 18.5 & 3.3 \\
\hline & 増減率 & & & -2.7 & -1.4 & & +68.7 & -0.1 & +2.9 \\
\hline
\end{tabular}

第15図 雌性家鬼に対する T.P.1 mg/kopf 5 日間投与実験

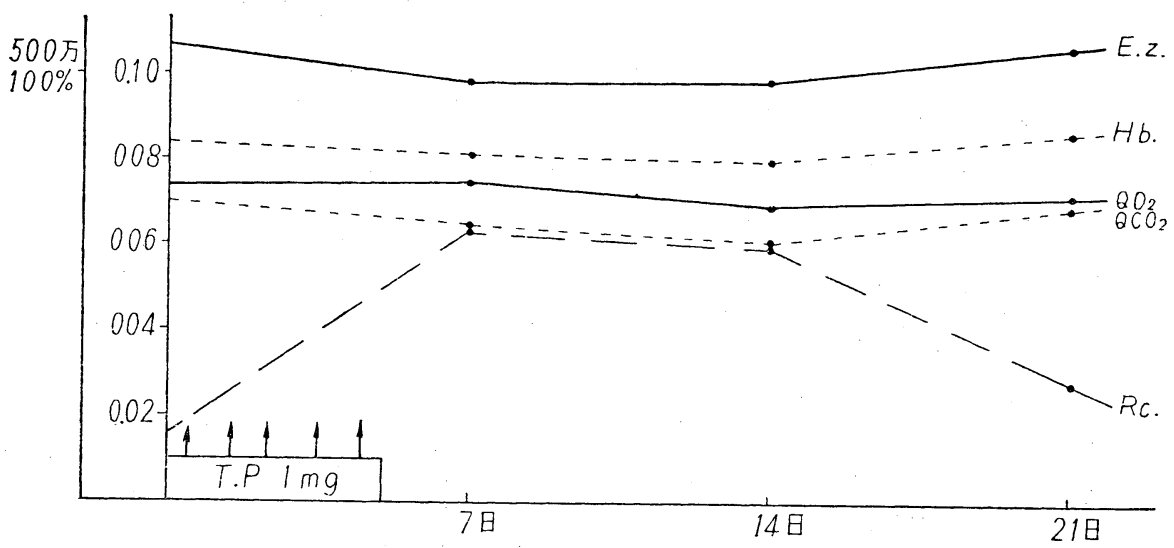

雌性家鬼に対するT．P．1 mg 5 日間連続投与による赤血球呼吸及び末梢血液像の変動は第 19 表及び第 15 図に示す如くである.

即ち雔性群に於てはT.P.投与により第7 日は $\mathrm{QO}_{2}+1.4 \%, \mathrm{QCO}_{2}-8.6 \%$ の増減にて著変を認めない が網状赤血球数は $+293.8 \%$ の著増を示す。第14日には $\mathrm{QO}_{2}-6.8 \%, \mathrm{QCO}_{2}-14.3 \%$ で $\mathrm{QCO}_{2}$ の減少を 認めるが第21日には前値への恢復傾向を認める。

（3） T.P.投与により雌雄両性共網状赤血球数の著明な增加を示すが成熟赤血球呼吸の変動には差異を談

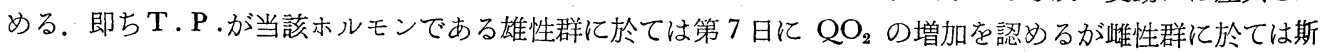
る $\mathrm{QO}_{2}$ の増加を認めない. 第14日に於ては雌雄両性群共 $\mathrm{QCO}_{2}$ の堿少を認めた。

\section{第 2 節 雄性性腺剔出の影響}

男性ホルモン過少環境の赤血球呼吸に及ばす影響を検索する為, 成熟雄性家香に去勢手術を行い赤血球呼

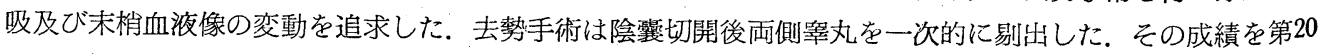


表及び第16図に示す.

即ち淕丸剔出により赤血球呼吸は正常值に比し第10日 $\mathrm{QO}_{2}-11.1 \%, \mathrm{QCO}_{2}-16.7 \%$ ，第20日 $\mathrm{QO}_{2}-$

第20表雄些々腺剔出実験

\begin{tabular}{|c|c|c|c|c|c|c|c|c|c|}
\hline 術後 & 家鬼番号 & & 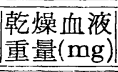 & $\mathrm{QO}_{2}$ & $\mathrm{QCO}_{2}$ & $\mathrm{RQ}$ & 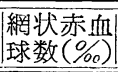 & $\begin{array}{l}\text { 赤血球数 } \\
\left(\times 10^{4}\right)\end{array}$ & $\begin{array}{l}\text { 血色素量 } \\
(\%)\end{array}$ \\
\hline \multirow{13}{*}{$\begin{array}{l}\text { 第 } \\
10 \\
\text { 日 }\end{array}$} & No. 135 & $\hat{\delta}$ & 190.5 & 0.078 & 0.099 & 1.269 & 50 & 550 & 80 \\
\hline & 136 & $\hat{\delta}$ & 169.0 & 0.061 & 0.060 & 0.984 & 32 & 509 & 94 \\
\hline & 137 & $\hat{\delta}$ & 162.5 & 0.057 & 0.051 & 0.895 & 31 & 534 & 80 \\
\hline & 138 & $\hat{\delta}$ & 160.0 & 0.069 & 0.059 & 0.855 & 30 & 526 & 84 \\
\hline & 139 & $\hat{\delta}$ & 204.5 & 0.059 & 0.058 & 0.983 & 21 & 490 & 80 \\
\hline & 140 & $\hat{\delta}$ & 185.5 & 0.068 & 0.061 & 0.897 & 74 & 542 & 85 \\
\hline & 141 & $\hat{\jmath}$ & 206.5 & 0.067 & 0.053 & 0.791 & 11 & 532 & 90 \\
\hline & 142 & 令 & 160.5 & 0.058 & 0.050 & 0.862 & 27 & 512 & 85 \\
\hline & 143 & $\hat{\delta}$ & 198.5 & 0.055 & 0.047 & 0.855 & 42 & 509 & 85 \\
\hline & 144 & $\hat{\delta}$ & 163.5 & 0.069 & 0.056 & 0.812 & 20 & 533 & 83 \\
\hline & 平均値 & & & 0.064 & 0.060 & 0.927 & 33.8 & 523.7 & 84.6 \\
\hline & 偏 差 & & & 0.007 & 0.009 & & 17.9 & 18.5 & 4.6 \\
\hline & 增減率 & & & -11.1 & -16.7 & & +100.0 & -2.4 & +1.0 \\
\hline \multirow{13}{*}{$\begin{array}{l}\text { 第 } \\
\text { 日 }\end{array}$} & No. 135 & $\hat{\delta}$ & 198.5 & 0.046 & 0.040 & 0.869 & 20 & 550 & 85 \\
\hline & 136 & $\hat{o}$ & 161.3 & 0.053 & 0.045 & 0.849 & 23 & 495 & 80 \\
\hline & 137 & $\hat{\delta}$ & 203.0 & 0.049 & 0.043 & 0.877 & 26 & 505 & 80 \\
\hline & 138 & $\hat{\delta}$ & 192.2 & 0.051 & 0.040 & 0.784 & 30 & 515 & 85 \\
\hline & 139 & 令 & 171.5 & 0.047 & 0.042 & 0.894 & 34 & 546 & 90 \\
\hline & 140 & $\hat{\beta}$ & 192.0 & 0.058 & 0.045 & 0.776 & 54 & 450 & 77 \\
\hline & 141 & 今 & 182.5 & 0.049 & 0.047 & 0.959 & 32 & 476 & 83 \\
\hline & 142 & $\hat{\delta}$ & 183.5 & 0.048 & 0.043 & 0.896 & 33 & 492 & 82 \\
\hline & 143 & $\hat{\delta}$ & 179.5 & 0.052 & 0.044 & 0.846 & 61 & 528 & 90 \\
\hline & 144 & $\hat{o}$ & 144.5 & 0.058 & 0.051 & 0.879 & 43 & 548 & 85 \\
\hline & 平均値 & & & 0.051 & 0.044 & 0.861 & 35.6 & 510.5 & 83.7 \\
\hline & 偏 差 & & & 0.005 & 0.004 & & 13.6 & 33.3 & 4.3 \\
\hline & 增減率 & & & -29.2 & -38.9 & & +110.6 & -4.9 & -0.1 \\
\hline \multirow{13}{*}{$\begin{array}{l}\text { 第 } \\
30 \\
\text { 日 }\end{array}$} & No. 135 & $\hat{\delta}$ & 191.5 & 0.093 & 0.073 & 0.785 & 16 & 503 & 85 \\
\hline & 136 & $\hat{\delta}$ & 167.5 & 0.071 & 0.060 & 0.845 & 25 & 505 & 80 \\
\hline & 137 & 今 & 156.5 & 0.081 & 0.067 & 0.827 & 29 & 486 & 80 \\
\hline & 138 & $\hat{\imath}$ & 181.0 & 0.066 & 0.054 & 0.818 & 24 & 503 & 83 \\
\hline & 139 & 占 & 170.5 & 0.083 & 0.071 & 0.855 & 19 & 541 & 90 \\
\hline & 140 & 全 & 180.0 & 0.069 & 0.060 & 0.869 & 37 & 493 & 80 \\
\hline & 141 & $\hat{\delta}$ & 175.0 & 0.073 & 0.067 & 0.918 & 54 & 513 & 85 \\
\hline & 142 & $\hat{\delta}$ & 214.0 & 0.074 & 0.063 & 0.851 & 63 & 512 & 87 \\
\hline & 143 & $\hat{\beta}$ & 183.0 & 0.058 & 0.042 & 0.724 & 64 & 523 & 84 \\
\hline & 144 & 令 & 152.5 & 0.067 & 0.060 & 0.895 & 34 & 530 & 88 \\
\hline & 平均值 & & & 0.074 & 0.062 & 0.839 & 36.5 & 510.9 & 84.2 \\
\hline & 偏 差 & & & 0.010 & 0.009 & & 17.8 & 16.8 & 3.5 \\
\hline & 増減率 & & & +2.8 & -13.9 & & +116.0 & -4.9 & +0.5 \\
\hline
\end{tabular}




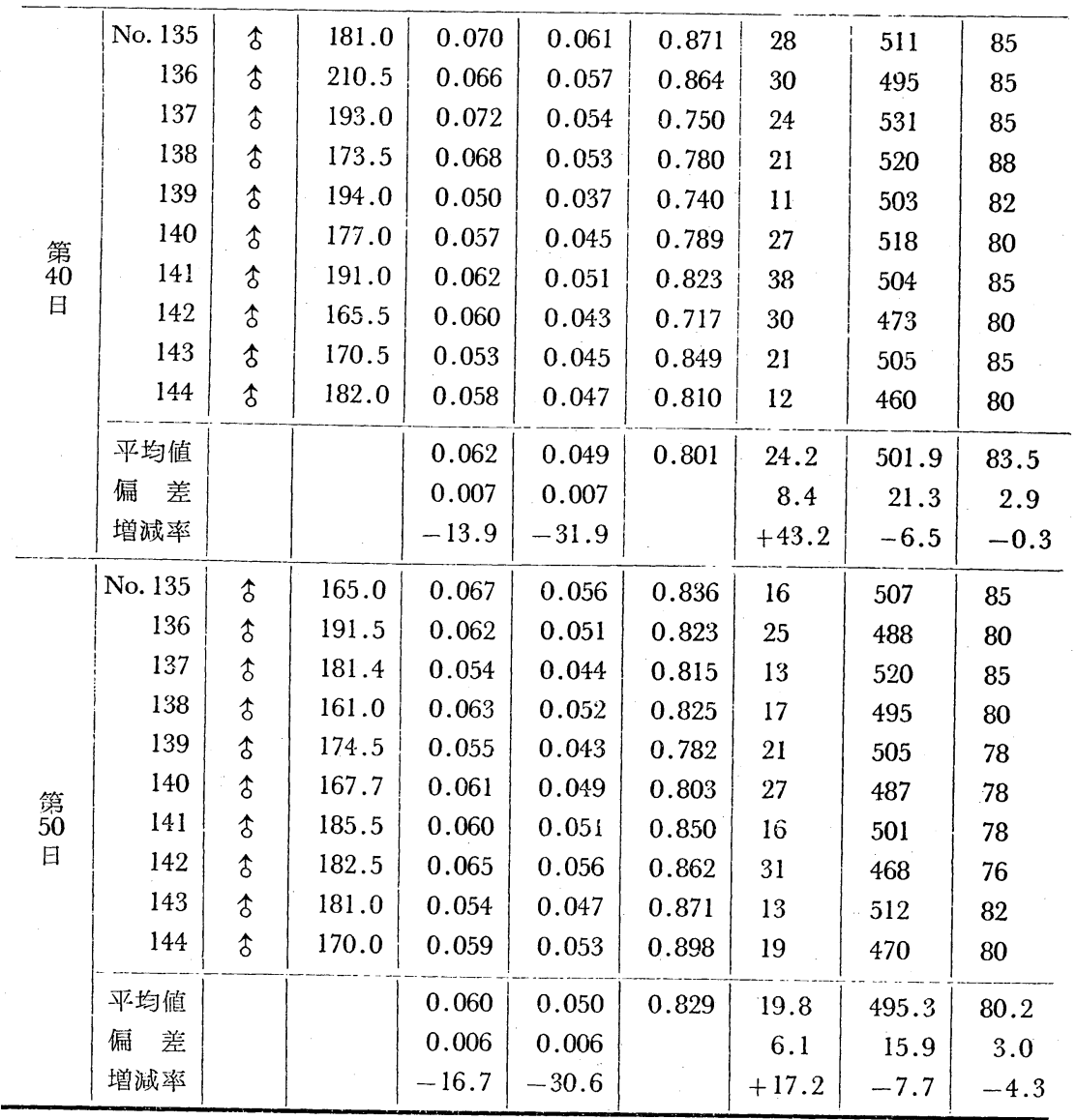

第16図 堆性々腺剔出㿤驗

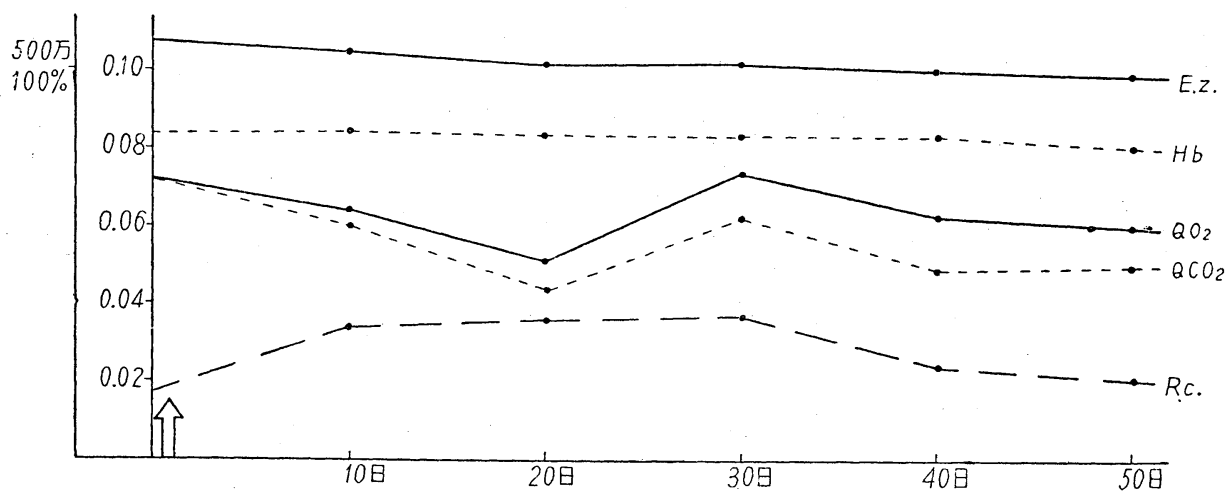

$29.2 \%, \mathrm{QCO}_{2}-38.9 \%$ の低下を示し 第20日に於ける低下は著明であるが第30日に於ては $\mathrm{QO}_{2}+2.8 \%$, $\mathrm{QCO}_{2}-13.9 \%$ の増減にて格々正常值の近く迄恢復傾向を示すが第 40 日, 第50日に於ては夫々 $\mathrm{QO}_{2}-13.9$ $\%,-16.7 \%, \mathrm{QCO}_{2}-31.9 \%,-30.6 \%$ の低下を示す。即ち辤丸剔出により赤血球呼吸は長期日後低下を示 
すが第30日に於ける上昇の如く一途に低下を来すあのではない，斯る傾向は網状赤血球数の变動にも見られ 即ち網状赤血球数は第 10 日 $+100.0 \%$ ，第 20 日 $+110.6 \% ，$ 第 30 日 $+116.0 \%$ の增加を示すが以後漸減傾向を 示す．赤血球数，血色素量は共に長期日後減少を認める.

\section{第 3 節 Estradiol benzoate 投与の影響}

女性ホルモンとして estradiol benzoate（以下E.B.と略す，ovahormon 帝国藏器製）を用い1,000単位 5 日間連続投与して過ホルモン環境を生ぜしめその赤血球呼吸及び末梢血液像に及ぼす影響を検索した。実 験は雌性群；雄性群に分つて行つた。

第21表 雌性家鬼に対する E.B.1.000U/KopJ 5 日間投与実跧

\begin{tabular}{|c|c|c|c|c|c|c|c|c|c|}
\hline & 家鬼番号 & & 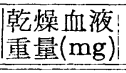 & $\mathrm{QO}_{2}$ & $\mathrm{QCO}_{2}$ & RQ & $\begin{array}{l}\text { 網状赤血 } \\
\text { 球数 }(\% 0)\end{array}$ & $\begin{array}{l}\text { 赤血球数 } \\
\left(\times 10^{4}\right)\end{array}$ & $\begin{array}{c}\text { 血色素量 } \\
(\%) \\
\end{array}$ \\
\hline \multirow{8}{*}{$\begin{array}{l}\text { 前 } \\
\text { 傎 }\end{array}$} & No. 25 & 우 & 181.5 & 0.072 & 0.071 & 0.986 & 18 & 500 & 80 \\
\hline & 26 & 우 & 182.0 & 0.068 & 0.076 & 1.168 & 21 & 535 & 80 \\
\hline & 29 & 우 & 176.0 & 0.083 & 0.093 & 1.120 & 24 & 539 & 80 \\
\hline & 32 & 오 & 178.5 & 0.080 & 0.085 & 1.063 & 14 & 548 & 85 \\
\hline & 33 & 우 & 182.5 & 0.070 & 0.061 & 0.871 & 16 & 545 & 85 \\
\hline & 平均值 & & & 0.075 & 0.077 & 1.027 & 18.6 & 533.4 & 82.0 \\
\hline & 偏 差 & & & 0.007 & 0.012 & & 4.0 & 19.4 & 2.7 \\
\hline & 増減率 & & & 0 & 0 & & 0 & 0 & 0 \\
\hline \multirow{8}{*}{$\begin{array}{c}\text { 第 } \\
7 \\
\text { 日 }\end{array}$} & No. 25 & 우 & 197.8 & 0.082 & 0.054 & 0.659 & 37 & 502 & 80 \\
\hline & 26 & 우 & 171.7 & 0.071 & 0.043 & 0.606 & 13 & 421 & 78 \\
\hline & 29 & 우 & 166.5 & 0.087 & 0.061 & 0.701 & 14 & 464 & 74 \\
\hline & 32 & 우 & 205.0 & 0.053 & 0.046 & 0.868 & 41 & 482 & 85 \\
\hline & 33 & 우 & 183.5 & 0.074 & 0.062 & 0.838 & 32 & 499 & 85 \\
\hline & 平均值 & & & 0.073 & 0.053 & 0.726 & 27.4 & 473.6 & 80.4 \\
\hline & 编 差 & & & 0.013 & 0.009 & & 13.2 & 33.1 & 4.8 \\
\hline & 增減率 & & & -2.7 & -31.2 & & +47.3 & -11.2 & -2.0 \\
\hline \multirow{8}{*}{$\begin{array}{l}\text { 第 } \\
14 \\
\text { 日 }\end{array}$} & No. 25 & 우 & 191.0 & 0.071 & 0.053 & 0.747 & 59 & 423 & 80 \\
\hline & 26 & 우 & 187.5 & 0.062 & 0.047 & 0.758 & 104 & 462 & 84 \\
\hline & 29 & 우 & 168.7 & 0.059 & 0.044 & 0.746 & 10 & 466 & 76 \\
\hline & 32 & 우 & 171.0 & 0.067 & 0.057 & 0.851 & 74 & 431 & 74 \\
\hline & 33 & 우 & 192.1 & 0.077 & 0.069 & 0.896 & 75 & 457 & 85 \\
\hline & 平均值 & & & 0.068 & 0.054 & 0.794 & 64.4 & 447.8 & 79.8 \\
\hline & 偏 茫 & & & 0.007 & 0.007 & & 34.5 & 19.5 & 4.8 \\
\hline & 增減率 & & & -9.3 & -29.9 & & +246.2 & -16.1 & -2.7 \\
\hline \multirow{8}{*}{$\begin{array}{l}\text { 第 } \\
21 \\
\text { 日 }\end{array}$} & No. 25 & 우 & 164.0 & 0.094 & 0.090 & 0.957 & 13 & 489 & 82 \\
\hline & 26 & 우 & 190.0 & 0.065 & 0.057 & 0.877 & 4 & 556 & 85 \\
\hline & 29 & 오 & 164.5 & 0.075 & 0.071 & 0.947 & 21 & 504 & 80 \\
\hline & 32 & 우 & 183.5 & 0.071 & 0.066 & 0.930 & 51 & 528 & 80 \\
\hline & 33 & 우 & 187.2 & 0.070 & 0.067 & 0.957 & 18 & 531 & 85 \\
\hline & 平均做 & & & 0.075 & 0.071 & 0.947 & 21.4 & 521.6 & 82.4 \\
\hline & 偏 差 & & & 0.005 & 0.006 & & 5.7 & 26.0 & 2.6 \\
\hline & 増減率 & & & 0 & -7.8 & & +15.1 & -2.2 & +0.5 \\
\hline
\end{tabular}




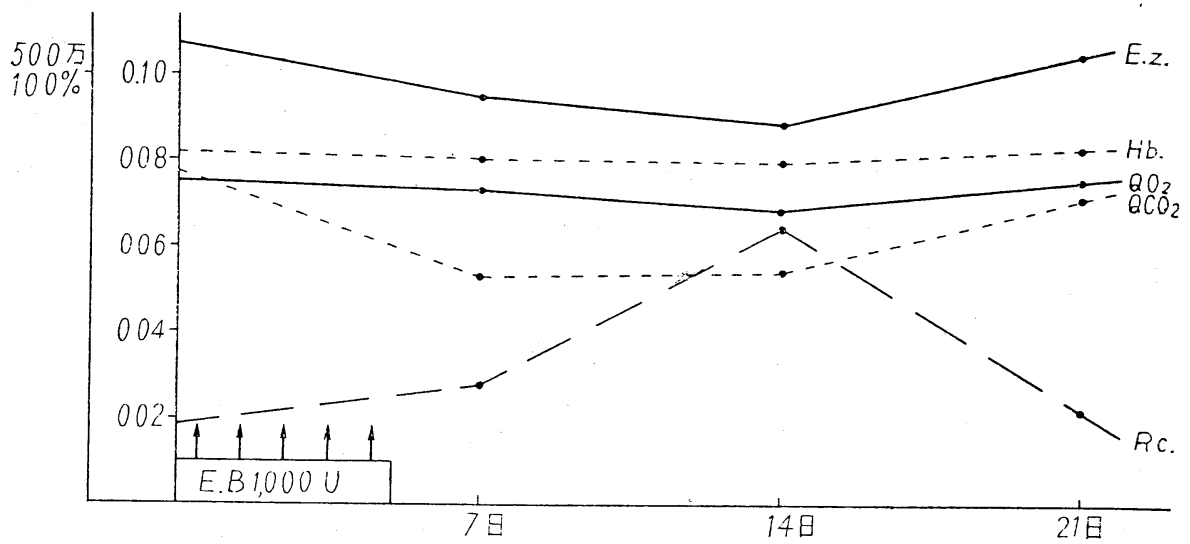

（1）雌性家鬼に対するE．B．1,000単位連続投与の影響

雌性家鬼に対するE．Ｂ．1,000算位連続投与による赤血球呼吸及び末梢血淮像の变動は第21表及ご第17図 に示守如くである。

即ち雌性群に刘する $\mathrm{E} . \mathrm{B}$.連続投与による赤血球呼吸の变動は $\mathrm{QO}_{2}$ は著变を認めないが $\mathrm{QCO}_{2}$ は第 7 日-31.2\%，第14日-29.9\%の減少を認める。網状赤血球数は第 7 日は著変を示さないが第14日は＋246.2 $\%$ 增加を示す．赤血球数は第 7 日 $-11.2 \%$ ，第14日-16.1\%の減少を認める。之らの変化は第21日には前 储への恢復傾向を示した。

(2) 雄性家鬼仗対するE．B・1,000単位連続投与の影響

雄性家鬼に対するE．B.投与による变動は第22表及び第18図に示す如くである。

第22表 雄性家雭に対する E.B.1.000U/Kopf 5 日間投与実鰻

\begin{tabular}{|c|c|c|c|c|c|c|c|c|c|}
\hline & 家雨番号 & & $\mid \begin{array}{l}\mid \text { 乾燥血液 } \\
\text { 重量 }(\mathrm{mg})\end{array}$ & $\mathrm{QO}_{2}$ & $\mathrm{QCO}_{2}$ & $\mathrm{RQ}$ & $\begin{array}{l}\text { 絧状赤血 } \\
\text { 球数 }(\% o)\end{array}$ & $\begin{array}{l}\text { 㫱血球数 } \\
\left(\times 10^{4}\right)\end{array}$ & $\begin{array}{c}\text { 血色素量 } \\
(\%)\end{array}$ \\
\hline \multirow{8}{*}{$\begin{array}{l}\text { 前 } \\
\text { 值 }\end{array}$} & No. 27 & $\hat{\delta}$ & 190.5 & 0.063 & 0.070 & 1.111 & 14 & 550 & 80 \\
\hline & 28 & $\hat{\delta}$ & 181.3 & 0.076 & 0.073 & 0.965 & 21 & 562 & 90 \\
\hline & 30 & $\hat{o}$ & 165.2 & 0.075 & 0.076 & 1.013 & 10 & 527 & 85 \\
\hline & 31 & $\hat{o}$ & 200.7 & 0.085 & 0.071 & 0.835 & 19 & 510 & 80 \\
\hline & 34 & $\hat{o}$ & 182.1 & 0.074 & 0.067 & 0.905 & 17 & 522 & 80 \\
\hline & 平均值 & & & 0.075 & 0.072 & 0.960 & 16.2 & 534.2 & 83.0 \\
\hline & 偏 差 & & & 0.008 & 0.005 & & 4.6 & 21.3 & 4.5 \\
\hline & 増娍率 & 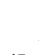 & & 0 & 0 & & 0 & 0 & 0 \\
\hline \multirow{3}{*}{-..- - } & No. 27 & $\hat{\delta}$ & 187.0 & 0.048 & 0.042 & 0.875 & 25 & 486 & 80 \\
\hline & 28 & $\hat{o}$ & 163.5 & 0.054 & 0.047 & 0.870 & 23 & 492 & 78 \\
\hline & 30 & $\hat{o}$ & 176.5 & 0.062 & 0.050 & 0.807 & 32 & 476 & 75 \\
\hline \multirow{5}{*}{$\begin{array}{c}\text { 第 } \\
7 \\
\text { 日 }\end{array}$} & 31 & $\hat{o}$ & 191.0 & 0.058 & 0.046 & 0.793 & 19 & 495 & 80 \\
\hline & 34 & $\hat{\delta}$ & 162.0 & 0.067 & 0.051 & 0.761 & 20 & 506 & 80 \\
\hline & 平均值 & & & 0.058 & 0.047 & 0.811 & 23.8 & 491 & 78.6 \\
\hline & 偏 差 & & & 0.007 & 0.005 & & 5.3 & 11.1 & 2.2 \\
\hline & 増減率 & & & -22.7 & -34.7 & & +46.9 & -8.1 & -5.3 \\
\hline
\end{tabular}




\begin{tabular}{|c|c|c|c|c|c|c|c|c|c|}
\hline \multirow{8}{*}{$\begin{array}{l}\text { 第 } \\
14 \\
\text { 日 }\end{array}$} & No. 27 & $\hat{o}$ & 172.1 & 0.063 & 0.054 & 0.857 & 21 & 437 & 72 \\
\hline & 28 & $\hat{\delta}$ & 167.7 & 0.068 & 0.052 & 0.765 & 40 & 480 & 79 \\
\hline & 30 & $\hat{\delta}$ & 205.5 & 0.073 & 0.064 & 0.877 & 51 & 429 & 74 \\
\hline & 31 & $\hat{o}$ & 180.0 & 0.061 & 0.055 & 0.902 & 31 & 450 & 75 \\
\hline & 34 & $\hat{\delta}$ & 182.5 & 0.069 & 0.061 & 0.884 & 60 & 498 & 80 \\
\hline & 平均値 & & & 0.067 & 0.057 & 0.851 & 40.6 & 458.8 & 76.0 \\
\hline & 偏 差 & & & 0.006 & 0.005 & & 23.5 & 29.7 & 3.6 \\
\hline & 增減率 & & & -10.7 & -20.8 & & +150.6 & -14.1 & -8.4 \\
\hline \multirow{8}{*}{$\begin{array}{l}\text { 第 } \\
\text { 日 }\end{array}$} & No. 27 & $\hat{o}$ & 160.0 & 0.073 & 0.064 & 0.877 & 23 & 524 & 88 \\
\hline & 28 & $\hat{\delta}$ & 186.2 & 0.067 & 0.064 & 0.955 & 45 & 503 & 80 \\
\hline & 30 & $\hat{\delta}$ & 185.5 & 0.079 & 0.072 & 0.911 & 52 & 477 & 77 \\
\hline & 31 & 官 & 200.4 & 0.071 & 0.065 & 0.916 & 27 & 512 & 85 \\
\hline & 34 & 今 & 202.0 & 0.067 & 0.058 & 0.866 & 30 & 479 & 80 \\
\hline & 平均值 & & & 0.071 & 0.065 & 0.916 & 35.4 & 499.0 & 82.0 \\
\hline & 偏 差 & & & 0.006 & 0.006 & & 12.5 & 23.1 & 4.4 \\
\hline & 增減率 & & & -5.3 & -9.7 & & +118.5 & -6.6 & -1.2 \\
\hline
\end{tabular}

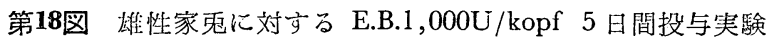

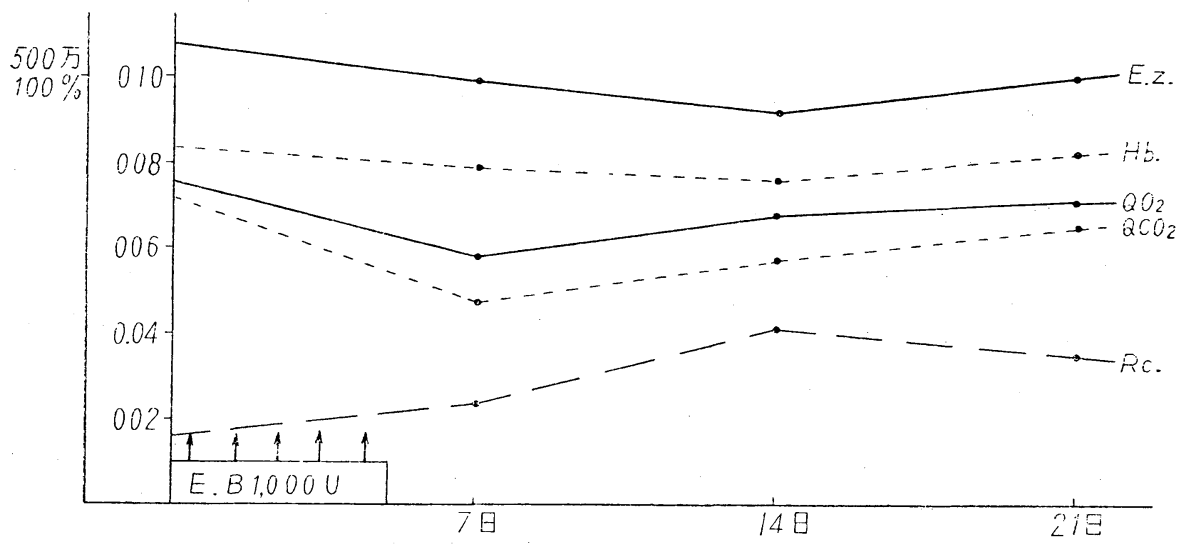

即ち雄性群に刘する E. B . 投与による赤血球呼吸の变陲は第 7 日 $\mathrm{QO}_{2}-22.7 \%, \mathrm{QCO}_{2}-34.7 \%$, 第 14 日 $\mathrm{QO}_{2}-10.7 \%, \mathrm{QCO}_{2}-20.8 \%$ の低下を示し赤血球呼四の抑制を認めるが第21日には前值への恢復傾向 を示す．一方網状赤血球数は第 7 日に於ては著明な増加を示さないが第14日には+150.6\%，第 21 日十118.5

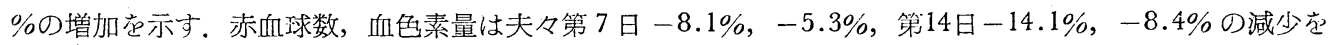
示すが第21日には前值への恢復傾向を認める.

（3）以上雌雄性雨群に対するE．B．の投与実験により E . B .は赤血球呼吸を抑制しかかる变化は雄性群に 刘する投与に於て特に著明であつだ網状赤血球数により示される造血機能に対しても E . B . は赤血球数， 们色素量の減少に比し寧乃抑制傾向を示した。

\section{第 4 節 望性性腺剔出の影響}

雌性成熟家鬼に去勢手術を行い女性ホルモン過少環境を生ぜしめその成熟赤血球呼吸に及方影響を椎索

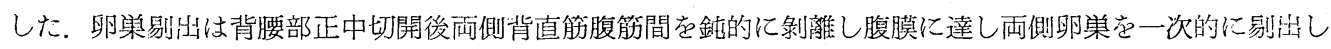




\section{た. 実験成績は第23表及び第19図に示す如くである.}

即ち雌性成熟家鬼仁去隼手術を行う之赤血球呼吸は正常值に比し術後第 10 日 $\mathrm{QO}_{2}-1.4 \%, \mathrm{QCO}_{2}-8.3 \%$, 第2 20 日 $\mathrm{QO}_{2}-13.9 \%, \mathrm{QCO}_{2}-25.0 \%$ の低下を示し手術対照群に比し第 20 日に於て赤血球呼吸の低下を見

第23表 雌 雄 性腺剔出実験

\begin{tabular}{|c|c|c|c|c|c|c|c|c|c|}
\hline 術後 & 家鬼番号 & & $\begin{array}{l}\text { 乾燥血液 } \\
\text { 重量(mg) }\end{array}$ & $\mathrm{QO}_{2}$ & $\mathrm{QCO}_{2}$ & RQ & $\begin{array}{l}\text { 網状赤血 } \\
\text { 球数 }(\%)\end{array}$ & $\begin{array}{c}\text { 赤血球数 } \\
\left(\times 10^{4}\right)\end{array}$ & $\begin{array}{c}\text { 血色素量 } \\
(\%) \\
\end{array}$ \\
\hline \multirow{9}{*}{ 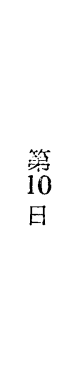 } & No. 145 & 우 & 160.0 & 0.079 & 0.078 & 0.988 & 41 & 500 & 85 \\
\hline & 146 & q & 183.5 & 0.091 & 0.079 & 0.868 & 54 & 489 & 80 \\
\hline & 147 & 우 & 208.0 & 0.054 & 0.050 & 0.926 & 87 & 446 & 77 \\
\hline & 148 & 우 & 173.5 & 0.061 & 0.057 & 0.934 & 31 & 479 & 75 \\
\hline & 149 & 우 & 186.4 & 0.073 & 0.068 & 0.931 & 46 & 499 & 82 \\
\hline & 150 & 우 & 188.5 & 0.066 & 0.065 & 0.985 & 27 & 498 & 84 \\
\hline & 活均做 & & & 0.071 & 0.066 & 0.930 & 47.7 & 485.2 & 80.5 \\
\hline & 缩 差: & & & 0.013 & 0.011 & & 20.9 & 19.9 & 4.0 \\
\hline & 增娍渠 & & & -1.4 & -8.3 & & +182.2 & -9.6 & -3.9 \\
\hline \multirow{9}{*}{$\begin{array}{l}\text { 第 } \\
20 \\
\text { 日 }\end{array}$} & No. 145 & 우 & 162.0 & 0.055 & 0.045 & 0.818 & 12 & 576 & 95 \\
\hline & 146 & 우 & 197.5 & 0.064 & 0.052 & 0.813 & 42 & 542 & 82 \\
\hline & 147 & 우 & 155.0 & 0.056 & 0.047 & 0.839 & 46 & 508 & 84 \\
\hline & 148 & 우 & 202.0 & 0.062 & 0.055 & 0.887 & 30 & 507 & 85 \\
\hline & 149 & 우 & 192.0 & 0.071 & 0.066 & 0.930 & 28 & 525 & 85 \\
\hline & 150 & 우 & 193.0 & 0.061 & 0.057 & 0.935 & 28 & 495 & 80 \\
\hline & 扱均随 & & & 0.062 & 0.054 & 0.871 & 31.0 & 525.5 & 85.2 \\
\hline & 缩 美 & & & 0.006 & 0.008 & & 16.3 & 30.0 & 5.2 \\
\hline & 增墄渗 & & & -13.9 & -25.0 & & +83.4 & -2.1 & +1.7 \\
\hline \multirow{9}{*}{$\begin{array}{l}\text { 第 } \\
30 \\
\text { 日 }\end{array}$} & No. 145 & 우 & 197.0 & 0.062 & 0.053 & 0.855 & 31 & 491 & 80 \\
\hline & 146 & 우 & 168.5 & 0.064 & 0.053 & 0.828 & 59 & 536 & 85 \\
\hline & 147 & 우 & 179.5 & 0.063 & 0.054 & 0.857 & 48 & 482 & 83 \\
\hline & 148 & 우 & 191.5 & 0.078 & 0.073 & 0.936 & 57 & 496 & 82 \\
\hline & 149 & c c & 172.5 & 0.069 & 0.061 & 0.884 & 33 & 508 & 80 \\
\hline & 150 & 우 & 189.5 & 0.085 & 0.070 & 0.824 & 54 & 525 & 90 \\
\hline & 平约値 & & & 0.070 & 0.061 & 0.871 & 47.0 & 506.0 & 83.3 \\
\hline & 雀 崖 & & & 0.009 & 0.009 & & 12.3 & 20.9 & 3.8 \\
\hline & 堌娍濐 & & & -2.8 & -15.3 & & +178.1 & -5.8 & -0.6 \\
\hline \multirow{9}{*}{$\begin{array}{l}\text { 策 } \\
40 \\
\text { 日 }\end{array}$} & No. 145 & 우 & 164.0 & 0.054 & 0.053 & 0.828 & 35 & 528 & 85 \\
\hline & 146 & 우 & 178.0 & 0.053 & 0.040 & 0.755 & 31 & 540 & 90 \\
\hline & 147 & 우 & 170.0 & 0.061 & 0.054 & 0.885 & 49 & 552 & 90 \\
\hline & 148 & 우 & 206.5 & 0.072 & 0.065 & 0.903 & 43 & 468 & 77 \\
\hline & 149 & 우 & 185.4 & 0.063 & 0.049 & 0.778 & 38 & 508 & 85 \\
\hline & 150 & 우 & 202.5 & 0.068 & 0.054 & 0.794 & 46 & 525 & 88 \\
\hline & 平均檤 & & & 0.064 & 0.053 & 0.828 & 40.3 & 520.2 & 85.8 \\
\hline & 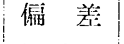 & & & 0.007 & 0.008 & & 6.9 & 29.6 & 4.9 \\
\hline & 橧減率 & & & -11.1 & -26.4 & & +138.5 & -3.1 & +2.4 \\
\hline
\end{tabular}




\begin{tabular}{|c|c|c|c|c|c|c|c|c|c|}
\hline \multirow{9}{*}{$\begin{array}{l}\text { 第 } \\
50 \\
\text { 日 }\end{array}$} & No. 145 & 우 & 184.5 & 0.074 & 0.064 & 0.865 & 21 & 532 & 88 \\
\hline & 146 & 우 & 160.0 & 0.062 & 0.053 & 0.853 & 35 & 535 & 85 \\
\hline & 147 & 우 & 171.5 & 0.071 & 0.066 & 0.930 & 28 & 520 & 85 \\
\hline & 148 & 오 & 176.0 & 0.076 & 0.064 & 0.842 & 42 & 497 & 80 \\
\hline & 149 & 우 & 160.5 & 0.060 & 0.050 & 0.833 & 19 & 509 & 82 \\
\hline & 150 & 우 & 188.7 & 0.067 & 0.065 & 0.970 & 37 & 511 & 83 \\
\hline & 平均值 & & & 0.068 & 0.60 & 0.884 & 30.3 & 517.3 & 83.8 \\
\hline & 偏 差 & & & 0.007 & 0.007 & & 11.7 & 11.5 & 2.8 \\
\hline & 堌減率 & & & -5.6 & -16.7 & & +79.3 & -3.6 & 0 \\
\hline
\end{tabular}

第19図，䧳性々腺剔出笑弱

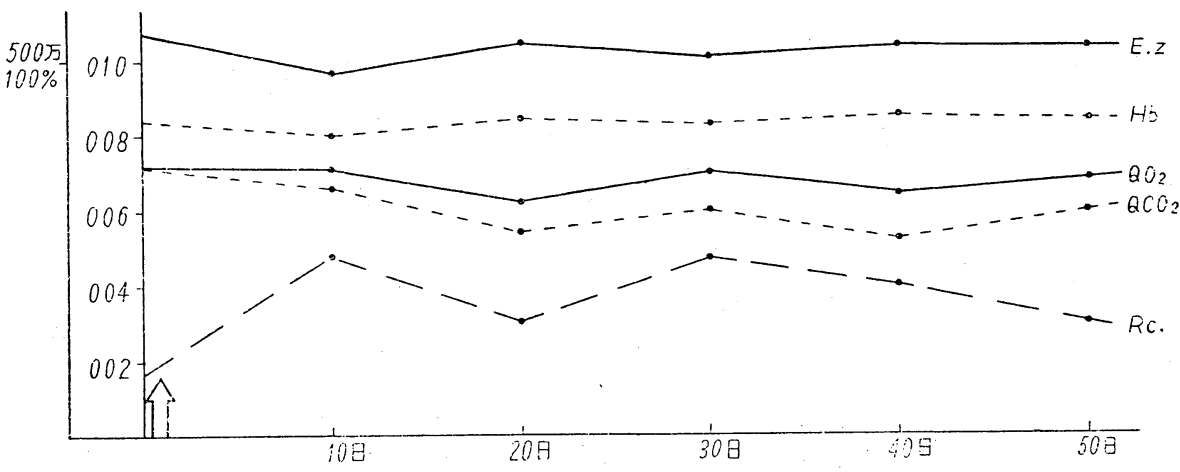

ろが第30日に於ては $\mathrm{QO}_{2}-2.8 \%, \mathrm{QCO}_{3}-15.3 \%$ と正常值への恢復傾向を示すが術後第40日，第50日に於 ては夫々 $\mathrm{QO}_{2}-11.1 \%,-5.6 \%, \mathrm{QCO}_{2}-26.4 \%,-16.7 \%$ の減少を示す。一方網状赤血球数は術後第 10 日 $+182.2 \%$ ，第20日 $+83.4 \%$ ，第30日 $+178.1 \%$ ，第40日 $+138.5 \% ，$ 第50日 $+79.3 \%$ の各增加を示す. 赤血 球数, 血色素量は手術侵襲対照群に比し藷变を㒻ない.

\section{第 5 節 性ホルモン試験節内添加による影響}

性ホルモンの試験管内添加による組織への直接作用の検索は種々行わ犸ているぶ一定の傾向をみない. 藷

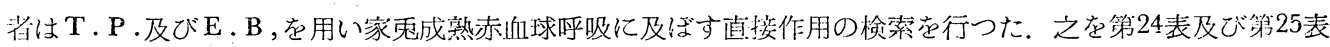
に示す。

即ちT.P.の添加によつては対照群 $\mathrm{QO}_{2}$ 0.068, $\mathrm{QCO}_{2}$ 0.069, RQ 1.009 に比し0.5r/cc, 1 r/cc, 5 r/cc

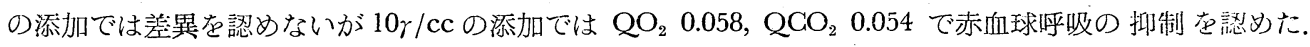
E.B. $0.5 \mathrm{U} / \mathrm{cc}, 5 \mathrm{U} / \mathrm{cc}, 10 \mathrm{U} / \mathrm{cc}$ の添加では対照に比し著明な促進乃至抑制効果を認めない.

\section{第 6 節 本章小括}

赤血球呼吸に及ぼす男性ホルモン，女性ホルモンの投与及び去奜の影㗽を以上の䒠験成績より要約すると 以下の如くである.

即ち T.P.在正常成熟雄性家鬼に $1 \mathrm{mg} ， 5$ 日間連続投与すると第 7 日に於て 絀状赤血球数の著増と共に 成熟赤血球の $\mathrm{QO}_{2}$ の増加をみるが $\mathrm{QCO}_{2}$ は第 7 日より第14日にかけて低下走示す．一方雌性成熟家鬼に T.P.を投与せる場合は網状赤血球の著増に拘らず成熟赤血球の呼吸は著変を示さない. 即ち T.P. $1 \mathrm{mg}$

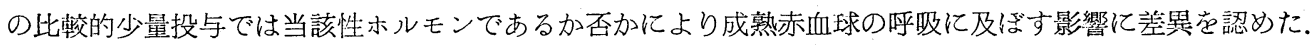

一开 E.B.1,000算位 5 日間の投与により㠛雄両群共第 7 日に於て網状赤血球の増加即ち造血袎能は抑制さ

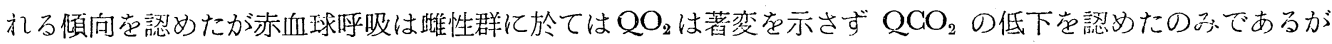


第24表 T.P. 試験管内添加実験

\begin{tabular}{|c|c|c|c|c|c|c|}
\hline T.P.添加量 & 家鬼番号 & & 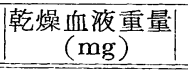 & $\mathrm{QO}_{2}$ & $\mathrm{QCO}_{2}$ & $\mathrm{RQ}$ \\
\hline \multirow{5}{*}{ 対照 } & No. 73 & $\hat{\delta}$ & 196.5 & 0.061 & 0.054 & 0.885 \\
\hline & 74 & $\hat{\delta}$ & 176.7 & 0.068 & 0.087 & 1.132 \\
\hline & 75 & $\hat{\delta}$ & 157.0 & 0.066 & 0.068 & 1.030 \\
\hline & 76 & 우 & 210.5 & 0.080 & 0.071 & 0.888 \\
\hline & 77 & 우 & 171.0 & 0.067 & 0.065 & 0.970 \\
\hline 平均值 & & & & 0.068 & 0.069 & 1.009 \\
\hline \multirow{5}{*}{$0.5 \gamma / \mathrm{cc}$} & No. 73 & $\hat{\delta}$ & 175.5 & 0.064 & 0.053 & 0.828 \\
\hline & 74 & $\hat{\delta}$ & 192.0 & 0.071 & 0.068 & 0.958 \\
\hline & 75 & $\hat{\delta}$ & 165.0 & 0.065 & 0.073 & 1.123 \\
\hline & 76 & 우 & 152.7 & 0.068 & 0.067 & 0.985 \\
\hline & 77 & 우 & 201.5 & 0.077 & 0.070 & 0.909 \\
\hline 平均值 & & & & 0.069 & 0.066 & 0.959 \\
\hline \multirow{5}{*}{$1_{\gamma} / \mathrm{cc}$} & No. 73 & $\hat{\delta}$ & 188.0 & 0.071 & 0.073 & 1.028 \\
\hline & 74 & $\hat{o}$ & 183.5 & 0.062 & 0.070 & 1.129 \\
\hline & 75 & $\hat{\delta}$ & 164.0 & 0.058 & 0.064 & 1.104 \\
\hline & 76 & 우 & 191.0 & 0.072 & 0.065 & 0.903 \\
\hline & 77 & 우 & 175.5 & 0.076 & 0.069 & 0.908 \\
\hline 平均值 & & & & 0.068 & 0.068 & 1.006 \\
\hline \multirow{5}{*}{$5 r / \mathrm{cc}$} & No. 73 & $\hat{\jmath}$ & 215.5 & 0.068 & 0.064 & 0.941 \\
\hline & 74 & 今 & 176.0 & 0.067 & 0.058 & 0.865 \\
\hline & 75 & $\hat{o}$ & 181.0 & 0.059 & 0.068 & 1.153 \\
\hline & 76 & 우 & 165.0 & 0.076 & 0.071 & 0.934 \\
\hline & 77 & 우 & 155.6 & 0.074 & 0.073 & 0.987 \\
\hline 平均値 & & & & 0.069 & 0.067 & 0.971 \\
\hline \multirow{5}{*}{$10 \gamma / \mathrm{cc}$} & No. 73 & $\hat{\delta}$ & 192.5 & 0.063 & 0.065 & 1.032 \\
\hline & 74 & $\hat{\delta}$ & 177.0 & 0.054 & 0.051 & 0.944 \\
\hline & 75 & 令 & 154.3 & 0.060 & 0.053 & 0.883 \\
\hline & 76 & 우 & 181.5 & 0.057 & 0.049 & 0.860 \\
\hline & 77 & 우 & 168.8 & 0.055 & 0.052 & 0.945 \\
\hline 平均值 & & & & 0.058 & 0.054 & 0.934 \\
\hline
\end{tabular}

婎性群に於ては $\mathrm{QO}_{2}, \mathrm{QCO}_{2}$ 共低下し赤血球呼吸の抑制を認めた。即ち E. B .が当該性ホルモンである場 合は赤血球呼吸抑制作用は軽度であつた。

去勢実験に於て，先ず䅸丸剔出は長時日後赤血球呼吸及び造血機能の低下を来す事を認めたが第20日に於 ける $\mathrm{QO}_{2}, \mathrm{QCO}_{2}$ の低下が第30日には兄進を示し再び低下する事より睪丸剔出による赤血球呼吸 及び造血 機能の減退方他因子により影響される事が推測される，雌性性腺剔出による変動む略々同様の傾向を示すが 赤血球呼吸，末梢血液像への影響は雄性性腺剔出々比し軽度である事が認められる.

T.P., E. B.の赤血球呼吸に及ばす直接作用は認め難いが T.P. 10r/cc の添加では抑制傾向がみられた. 
第25表 E.B. 試験管内添加実験

\begin{tabular}{|c|c|c|c|c|c|c|}
\hline E.B.添加量 & 家象番号 & & 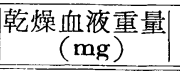 & $\mathrm{QO}_{2}$ & $\mathrm{QCO}_{2}$ & RQ \\
\hline \multirow{5}{*}{ 対照 } & No. 13 & 우 & 178.0 & 0.073 & 0.074 & 1.014 \\
\hline & 14 & 우 & 164.5 & 0.078 & 0.067 & 0.859 \\
\hline & 15 & 우 & 211.0 & 0.065 & 0.069 & 1.062 \\
\hline & 16 & $\hat{\delta}$ & 154.5 & 0.067 & 0.068 & 1.015 \\
\hline & 17 & $\hat{\delta}$ & 197.5 & 0.070 & 0.067 & 0.957 \\
\hline 平均値 & & & & 0.071 & 0.069 & 0.977 \\
\hline \multirow{5}{*}{$0.5 \mathrm{U} / \mathrm{cc}$} & No. 13 & 우 & 187.5 & 0.073 & 0.071 & 0.973 \\
\hline & 14 & 우 & 176.0 & 0.073 & 0.069 & 0.945 \\
\hline & 15 & q & 153.0 & 0.068 & 0.073 & 1.074 \\
\hline & 16 & $\hat{\delta}$ & 200.0 & 0.063 & 0.060 & 0.952 \\
\hline & 17 & $\hat{\circ}$ & 165.5 & 0.062 & 0.067 & 1.081 \\
\hline 平均値 & & & & 0.068 & 0.068 & 1.003 \\
\hline \multirow{5}{*}{$5 \mathrm{U} / \mathrm{cc}$} & No. 13 & 우 & 200.7 & 0.067 & 0.057 & 0.851 \\
\hline & 14 & 우 & 196.0 & 0.071 & 0.054 & 0.761 \\
\hline & 15 & 우 & 165.5 & 0.072 & 0.070 & 0.972 \\
\hline & 16 & $\hat{o}$ & 176.0 & 0.064 & 0.067 & 1.047 \\
\hline & 17 & $\hat{\delta}$ & 177.0 & 0.065 & 0.063 & 0.969 \\
\hline 平均值 & & & & 0.068 & 0.062 & 0.917 \\
\hline \multirow{5}{*}{$10 \mathrm{U} / \mathrm{cc}$} & No. 13 & 우 & 165.0 & 0.075 & 0.066 & 0.889 \\
\hline & 14 & 우 & 183.1 & 0.070 & 0.073 & 1.043 \\
\hline & 15 & 우 & 192.3 & 0.064 & 0.071 & 1.109 \\
\hline & 16 & $\hat{\delta}$ & 197.5 & 0.060 & 0.066 & 1.100 \\
\hline & 17 & 令 & 158.5 & 0.067 & 0.063 & 0.940 \\
\hline 平均值 & & & & 0.067 & 0.068 & 1.009 \\
\hline
\end{tabular}

\section{第六章 総括並びに考按}

著者は第 2 章より第 5 章に至る実験により赤血球呼吸が先人により明らかにされた如く肺機能，肝機能等 により影響されると共に，又内分泌腺機能により諸々の影響を蒙る事を知つた．甲状腺，副腎皮質，性腺等 の物質代謝に及ぼす影響に就ては近時下垂体一甲状腺系，下垂体一副㹂皮質系，下垂体一性腺系等に関する 研究を中心として種々の知見が明らかにされて来ている。一次性である下垂体前葉機能と二次性である各内 分泌腺相互間に密接な平衡調節関係の存在する事は松浦 ${ }^{54)}$ の神経内分泌調節説，或は森 $\left.{ }^{55}\right)$ の分泌自律神経 環境説等として一般に認められて居り内分必腺機能立進症及び低下症による物質代謝異常が多腺性の影響を 蒙る事が推測される。一方赤血球呼吸と密接な相関を有する骨䯣性造血機能が内分泌腺により強い支配を受 ける事は臨床的，実験的に明らかにされているが近時内分豊学の進歩と共に新たな観点より見直されつつあ る現状である。骨䯣性造血に影響を及ぼす内分泌腺として下垂体前葉，甲状腺，副婜皮質，性腺の血球調節 に関して多くの研究報告がある. 脳下垂体前葉に関しては古く1937年 Flask ${ }^{56)}$ 等により造血促進因子のある 事が報告され，近時再び Evans et al ${ }^{57758599}$ により pituitary erythropoietic hormone の提示が行われ既 知前葉ホルモンを除く新因子により骨髄性造血が特哄的に支配されているとして種々の実証を行つている. 
盰状腺，副腎皮岓，性腺の各種ホルモンの血球調節に及ぼす影響に就ては多くの事項が明らかにされてい

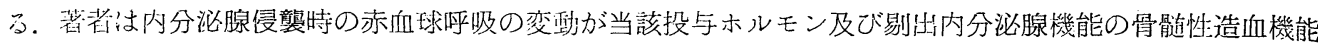

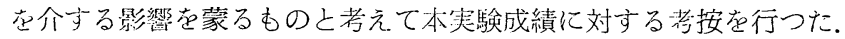

（1）甲状腺之赤血球呼吸

甲状腺機能の物質代謝に及ぼす影響に就ては臨乐的及び実験的に幾受の研究がなされてをり殊に組織の酸 化代謝に及ぼす影響に就ては in vivo, in vitro の実験により多くの事項が解明されている。状腺ホルモ ン投与による組織酸素消費の増加及び甲状腺剔出による減少が肝，腎，心笳，骨格筋，皮成等に於ては著明

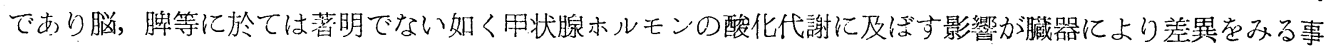
はBarker \& Klitgaard ${ }^{60)}$, Meyer \& Ranson ${ }^{\left.6_{1}\right)}$ 等多くの人々により明らかにされている. 又 in vitro の实験 に於て甲状腺ホルモンの組織酸素消費促進作用力㶓器により異る至適濃度を有し大量添加は逆に抑制する之

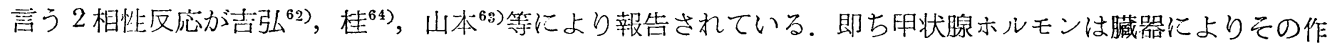
用强度を異にする事が明らかにされて妾りその酸化代謝に及ぽす影響が細胞内酸化還元酵素系を介するむの である事より細胞内䣼素量放至との活性促進作用に関寸る研究が行われているが甲状腺ホルモンの醇素系に 対する作用機転は未壮で允分に明らにされていない．

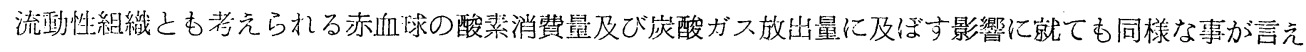
るのであるが赤血球呼吸は他藏器に比し微㦈であり且造血機能を介する影響や測定条件に左右される所が大 であるたり從来の報告は一定の傾向を認め難い，即ち従来の報告を見るに古くAnselmino et al ${ }^{653}$ (1929) は 漹鳥赤血球の $\mathrm{QO}_{2}$ が thyroxine $\left(4 \times 10^{-6} \sim 4 \times 10^{-5} \mathrm{M}\right)$ の試験管内添加により影響されない之報告し,

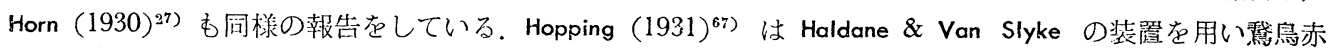
血球呼吸を検索し in vivo の甲状腺ホルモン投与により $\mathrm{QO}_{2}$ の增加を認めるす in vitro の添加及び incubate では変化涊めない事を報告している。 Issekntz et al は狂鳥赤血球の $\mathrm{QO}_{2}$ が thyroxine の in vivo 投与により增加するが thyroxine 投与動物の血漿は in vitro に於て赤血球呼吸に影響を及ぼさない と述べている. Scott et al 6) (1935) は緬を用い thyroxine の生体内投与が赤血球の $\mathrm{QO}_{2}$ 芷44\%上昇せ しめると共に in vivo, in vitro 共 thyroxine は $\mathrm{QO}_{2}$ を增加せしめるが $\mathrm{QCO}_{2}$ の增加は薪明でなく $\mathrm{RQ}$ ○低下堂来し，この RQ の低下は大量投与程著明であつた事を起皆している. Barker \& Klitgaard ${ }^{69)}$ (1951)

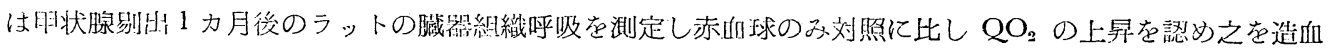

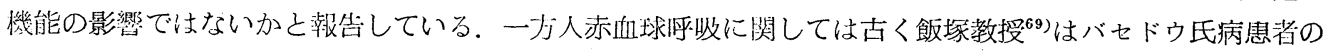

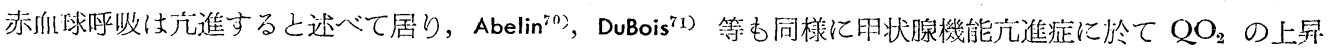
及び RQ の低下を報告している.

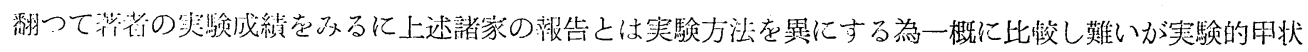
脉機能儿推症を代琵する thyradin 連続投与により $\mathrm{QO}_{2}$ は著增を示すが $\mathrm{QCO}_{2}$ の增加は起らず従つて $\mathrm{RQ}$ の低下危認めた。斯る $\mathrm{QO}_{2}$ の増加及び $\mathrm{RQ}$ の低下は大量投与群に於て特に著明であり，斯る $\mathrm{RQ}$

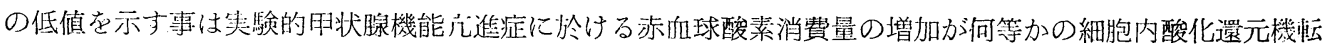

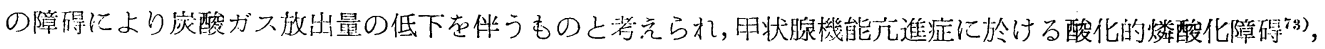

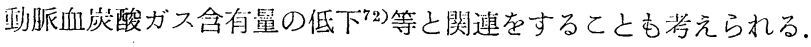

甲状腚剔出による笑験的甲状腺機能低下症に於ける赤血球呼吸の変泟は剔出後 第30日より $\mathrm{QO}_{2}, \mathrm{QCO}_{2}$, RQ の低下を認めた，斯る傾向は藏器組織呼吸に於ける变動と同一の経過を示すものである.

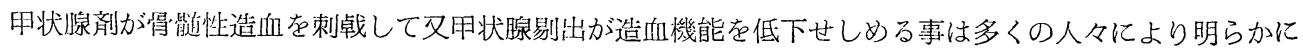

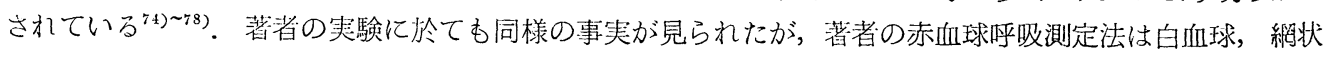
赤血球を略完全に除去した成熟赤血球の呼吸であるが成熟然核赤血球の幼若化による影響も幾分は存在する と思われる。而して in vitro に thyradin を添加せる場合の成績上り見て甲状腺ホルモンは直接赤血球呼 吸に影響を及ぼすむのと思われる。

赤扣球の酸素消費が血液解糖作用之密接な平行関係を有古る事は Bürger ${ }^{79)}$, Negelein ${ }^{80)}$, 川自 ${ }^{81)}$ 等により 
明らかにされているが加納 ${ }^{82}$ は thyradin 投与家鬼の血液グリコリーゼが增加し，甲状腺剔出により減少す ると報告している，甲状腺機能九進症及び低下症に於ては蛋白質，糖質を中心とした著明な異化代謝の变動 来来事が明らかにされているが赤血球呼吸の変動は之ら異化代謝の異常による血液生化学的性状の变化に 関連を有するものと思われる。

（2）副堅皮質之赤血球呼吸

副腎皮質より分泌されるホルモンは主として有機質の代謝関与する cortison, hydrocortison 等の glucocorticoids と，主として無機質の代謝に関与する aldosterone, DOC, DOGA 等の mineralcorticoids 及 び性ホルモンに大別される。

Cortisone の基礎代謝，蛋白頎代謝，糖質代謝，塩類及び水分代謝等に及ぼす影響に就ては多くの報告を 見る所である，正常動物の酸素消費に及ぼす影響に関しては逆方向の效果を示す甲状腺機能抑制作用に被方 れて明らかでなくなるぶ Hoff man ${ }^{\text {s3) }}$ ，Hill ${ }^{(4)}$ 等により甲状腺剔除時に cortison を投与すると基礎代謝を確実 に立進せしめる事が明らかとなつている。併乍ら cortison 投与による基礎代謝の充進が全ての臓器に於け る同一方向の異化代謝促進を示すむのでない事は正常及び副腎剔除動物に就ての多くの研究により明らかな

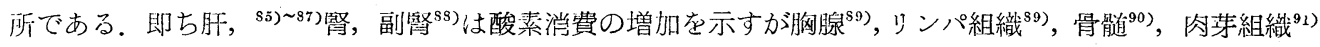
等は低下し脳 ${ }^{93}$ 筋は ${ }^{93}$ ，一定の傾向を走さない事が報告されている。赤血球の酸素消費に及ぼす影響に関し ては報告に接しないが著者の実験成績によかば正常家秋に cortison pro $\mathrm{kg} 5 \mathrm{mg}$ 連続投与せる場合は第 7 日に於て $\mathrm{QO}_{2}$ は著変なく $\mathrm{QCO}_{2}, \mathrm{RQ}$ の低下を示し第14日には $\mathrm{QO}_{2}$ は稍々增加を示す. 之に対し pro kg $2 \mathrm{mg}$ の少量を投与世る場合は第 7 日に $\mathrm{QO}_{2}$ の增加を示し第14日には $\mathrm{QO}_{2}$ は前值に復し $\mathrm{QCO}_{2}$ の低下 を示した. pro $\mathrm{kg} 5 \mathrm{mg}$ 投与碓では赤血球数, 血色素量の城少及び網状赤血球数の增加が著明であるが pro $\mathrm{kg} 2 \mathrm{mg}$ 投与群では同様の变化を認めたが前者程著明ではなかつた.

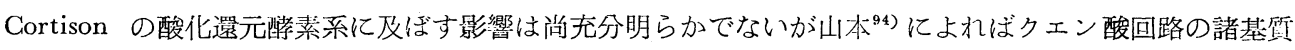

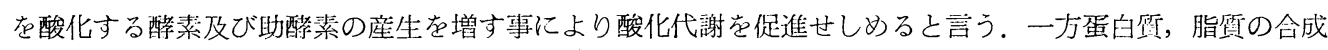

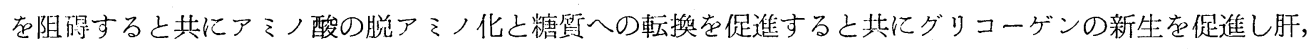
解のグリコーゲン量を增加せしめる事が知られてをり, 糖産生促進と共に未梢に於ける糖消費の抑制により 何糖を上昇せしめるとされている。一方血液グリコリーゼに及ばす影響に関し岸田 $\left.{ }^{95}\right)$ 等は副腎剔出により增 加した動物の血液ら゙リコリーゼは cortison 投与により抑例され正常動物に投与世る場合む軽度抑例傾向を みると報告している.

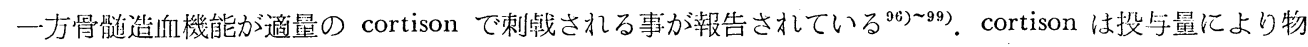
斦代謝，血液像，内分泌平衡等に及代す影響を異にするが落者の赤血球呼吸に及ぼす cortison 投与の影響

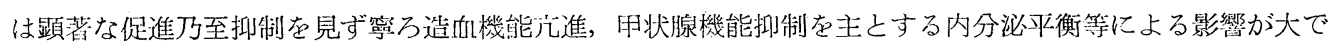
あり複雑な变化を示すものと思われる。

DOCA 恃主として水分及び電解斦代謝に関与する事が知られているが酸化代謝に対しては steroidhormone 中最も強い抑制作用在有する。即ち in vitro に於て比較的高濃度の DOC か这, 肝, 婜100) 102), 筋等

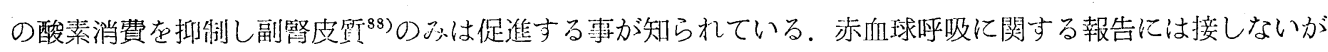
著者の実験成績によれば DOCA $2.5 \mathrm{mg}, \mathrm{lmg}$ 連続投与により何れも赤血球 $\mathrm{QO}_{2}, \mathrm{QCO}_{2}$ は著明に抑制さ れ殊に $2.5 \mathrm{mg}$ 投与群では $\mathrm{QCO}_{2} \mathrm{RQ}$ の低下が著明であつた。網状赤血球数に就ては $1 \mathrm{mg}$ 投与で注有意の

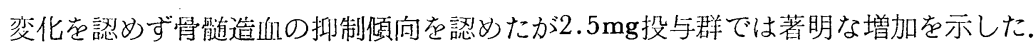

DOCA の酸化代謝抑制機転就ては種々の報告を見るも猶明らかではない. DOCA の生体内投与が体淮 $\mathrm{Na}$ 及び水分の賍溜を来す事は最屯藷明な效果であるが又蛋白代謝に対しても in vitro に於て DOC が蛋

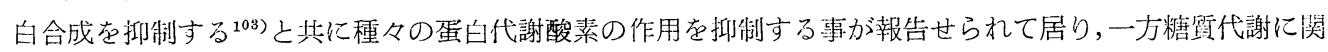
しても筋，肝に於けるクリコーゲン生成の抑制104)が in vitro の実験により報告されているが之らの作用は

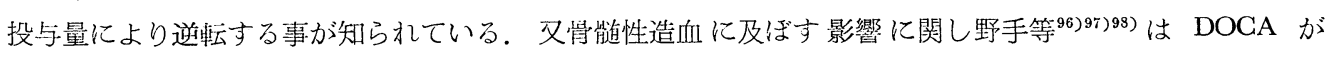
cortison と拮抗的な抑制效果をみると報告し佐伯 ${ }^{105)}$ は DOCA 投与時に偩血像をみないが細網内被系の増生 
を報告している．著者の実験成績に於ける少量投与群と大量投与群の網状赤血球数の変動は対照的な抑制及 び増加を示しているが赤血球呼吸は共に著明に抑制された。その機転に関しては今後の検討に待たねばなら ないか投与量により異る物質代謝抑制効果之共に血液電解質代謝異常による水血症の影響を蒙るすの之考光 られる。

副腎剔出により基礎代謝の低下する事は多くの報告により明らかな所であるが臟器組織酸素消費量に関し ては肝，婜に於ける低下が多く報告されている。Tripton ${ }^{85)}$ は副腎剔出動物の基礎代謝の低下は一般代謝機 能の減弱によるよりあある特別な臟器に於ける代謝障碍 の結果であると述べている，赤血球に関しては Gonzales et $\mathrm{al}^{106)}$ は白鼠副腎剔出により酸素消費量の著明な減弱を報告している.

著者の実験成績によれば家鬼片側副腎剔出後第 5 日に於ては手術対照群に比し $\mathrm{QO}_{2}, \mathrm{QCO}_{2}, \mathrm{RQ}$ 共有意 の差を認めないが両側剔出後第 5 日, 第10日に於ては $\mathrm{QO}_{2} \mathrm{QCO}_{2}$ は著明な低下を認めた。一方片側剔出後 網状赤血球数の增加を示し赤血球数, 血色素量の減少を示すが雨側剔出後は赤血球数, 血色素量共增加を示 す.

副斅剔出により生体は顕著な物質代謝障碍を起し生命維持困難な事が知られている。即ち糖質代謝に於て は肝糖原の消失と血糖低下 ${ }^{107}$ )を来し，血清蛋白像は Albumin 減少， $\gamma$-globulin ${ }^{108}$ 增加变来す. 更に顕著

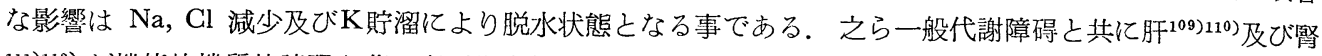
111)112) が機能的機質的障碍を蒙る事が幾多報告されている。一方骨髓造血機能は副腎剔出により低下する事 は Lewis ${ }^{133)}$,White ${ }^{114)}$ ，Van Dyke ${ }^{115)}$ 等により報告せられ未梢血中赤血球数，血色素量は血液濃縮の結果增 加する之言われる，副瞵剔出による赤血球呼吸の低下は蛋白質, 糖質, 無機質等の一般代謝障碍之共に肝及 び婜機能, 循環器機能の障碍等により顕著な低下を示すすのと考えられる.

（3）性腺之赤血球呼吸

性腺機能は従来雌雄性器に対する特異的性成熟作用に関して研究されて来たが近時性器外作用が注目され 殊に酸化代謝, 蛋白代謝, 造血調節等に及ばす影響に就ては多数の研究報告を見る所である.

Androgen は雄造性性器に対する発育促進作用之共に強い空素畄積, 蛋白同化促進作用を有する事が知ら

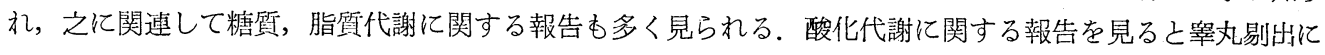
より低下せる肝，筜，筋等の $\mathrm{QO}_{2}$ 及び上昇せる 来すが前立腺, 精霍(199) は testosterone 投与により $\mathrm{QO}_{2}$ の增加を来す事が知られているが之らの醉素作用 に及ばす機転は充分明らかにされていない. ‘in vitro に於ては高濃度の testosterone は肝, 腎, 筋, 脳等 の $\mathrm{QO}_{2}$ を著明に抑制する ${ }^{120}$ が低濃度では肝，筋等の $\mathrm{QO}_{2}$ を增加せしめる1211222事が報告されている. 即ち androgen は投与量により組織酸素消費に及ばす影響を異にする事が知られている。赤血球呼吸に及

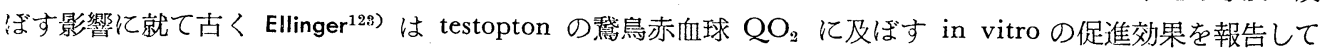
いる.

著者の実験成績によれば T.P $1 \mathrm{mg}$ の比校的少量を連続投与世る場合, 雄性成熟家鬼に於ては第 7 日に $\mathrm{QO}_{2}$ の增加及び第14日に $\mathrm{QCO}_{2}$ の娍少を認めるが，雌性成熟家鬼に於ては第7 日には $\mathrm{QO}_{2}, \mathrm{QCO}_{2}$ 共著 変なく第14日に $\mathrm{QCO}_{2}$ の減少を認める. 未悄血中網状赤血球数は雌雄共增加を示した.

骨髅性造血機能伩し androgen が促進的に作用する事は Finkelstein ${ }^{124}$, Bowman ${ }^{125)}$, 野手 ${ }^{96)}$, 佐伯 ${ }^{105)}$ 等 により明らかな所であつて androgen が正常及び䔂丸剔出動物の貿血恢復を促進する事が知られている. androgen の物質代謝に及ばす影響が雔雄により異る事は殊に蛋白同化作用に就て Kochakian ${ }^{126)}$ 等に上り明 らかにされている所であり肝, 腎等の酸素量に差異のある事む報告されている ${ }^{127)}$. Androgen 少量投与の赤血 球呼吸促進作用が牉雄により異り雌性群に於て顕著な增加を示さない事は異性ホルモン投与により之ら物質 代謝の差哄及び内分泌平衡の unbalance を生じる事によると思われる。

一方雄性性腺剔出を行うと長期日後 $\mathrm{QO}_{2}, \mathrm{QCO}_{2}, \mathrm{RQ}$ の低下を認めこの間第30日に於て一過性に恢復し その後再び低下を認めた。 この間網状赤血球数は增減区タであるが長時日後, 赤血球数, 血色素暴と共に漸 娍する。 
章丸剔出により 骨髄性造血機能 の低下を来し貧血 を生ずる事は Blacher ${ }^{128)}$, Taber ${ }^{129)}$, Steinglass ${ }^{150)}$, Van Dyke ${ }^{115)}$, Mc Cullagh ${ }^{131)}$ 等により明らかにされている。酸化代謝に関して舎丸剔出が肝, 腎, 筋等の $\mathrm{QO}_{2}$ を低下せしめ脳 $\mathrm{QO}_{3}$ を上昇せしめるが之に testosterone を投与すると更に低下せしめる事が Kochakian ${ }^{101)}$, Eisenberg ${ }^{116) 118)}$ ，川口等117)により明らか亿されているが，川口は去勢後第 2，3 週に於て下垂体，副腎等の 呼吸穴進を報告している，䔂丸剔出後 第30日に於ける赤血球呼吸，網状赤血球数の増加は睪丸剔出による

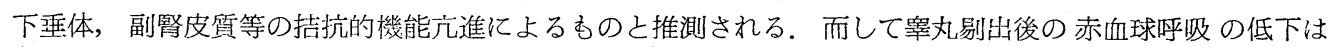
androgen 過少と共に他内分泌腺の多腺性失調による影響す関与するすのと推測される。

Estrogen は androgen の如き somatic growth 亿対する促進作用を有せずすしろ生長抑制的に作用する 事が知られている。酸化代謝に関しては子宮 ${ }^{132) 183)}$, 胎艋 ${ }^{134)}$ 等に就ては促進的に作用するが肝, 腎, 脳 ${ }^{120) 117)}$ 等は抑制される事が知られている。之ら estrogen の酸化代謝抑制機転に関し Mc Shau \& Meyer ${ }^{135)}$ は cytochrome 酸化酸素の抑制を述べている. 赤血球呼吸に及ばす estrogen の影響に就ては報告に接しない が著者の実験成績によればE．B.1,000単位の比較的少量を連続投与せる場合，雌性成熟家秉に於ては $\mathrm{QO}_{2}$ は著变を見ないが $\mathrm{QCO}_{2}$ は第 7 日，第14日共著明に抑制され $\mathrm{RQ}$ の低下を認めた. 雄性群に於ては $\mathrm{QO}_{2}$, $\mathrm{QCO}_{2}$ 共抑制される事虑認》た。網状赤血球数は雌雄両性共第 7 日に於ては增加せず第14日以後増加を示し

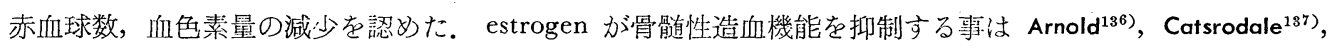
Crafts $^{138)}$ ，佐伯 ${ }^{105)}$ 等多くの人により認められてをり，佐伯によれば雄性群に於て貧血の発生は著明である と言う。 E . B . の赤血球呼吸抑制作册は酸化酸素系の抑制と共に造血機能の影響を蒙るものと思われるが雄

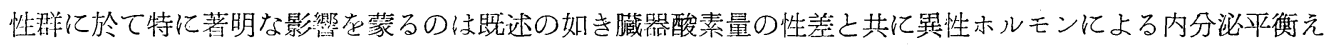
の影餡が敏感なる為之思われる。

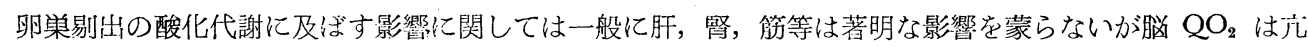
進する事が知られている ${ }^{117}$. 赤血球呼吸に就ての著者の奏験成䋶によれば去勢後第20日に於て $\mathrm{QO}_{2}, \mathrm{QCO}_{2}$ の低下をみるが第30日には恢復傾向を示し以後正常值に近い值を示す. 網状赤向球数む赤血球呼吸之略々同 一の变動を示した，赤血球数，血色素量は術後第10日に於て稍々減少を示すが以後前值に復し著变を示さ ない.

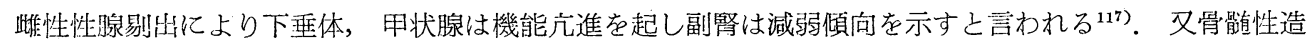
血機能は過形成とも云われる ${ }^{105)}$. 雌性性腺剔出による赤血球乎吸の変動は寧万之ら内分泌平衡の異常によ るむのであり長期的には直接の影響を蒙らないものと考えられる。

\section{第七章 結 論}

萿者は家鬼を用いホルモン㓣投与による過ホルモン環境及び内分泌腺剔出による低ホルモン環境の赤血球 呼昅に及ぼす影響を検討し, 併せて絧状赤血球数, 赤血球数, 血色素量の变動を追求し以下の結果を得た。

(1) Thyradin 投与による実験的甲状腺機能九進症に於ては赤血球酸素消費量の著增を認めるが放出炭酸 ガフ涟は堌加せず呼吸榢の低下をふる。

（2）甲状腺剔出による機能低下症に於ては赤血球酸素消費量, 放出炭酸ガス量, 呼吸商の低下を来す。

(3) Cortison 投与により赤血球酸素消費量は著変を認りないが放出炭酸ガス量, 呼吸商の低下を来す.

（4）DOCA 投与により赤血球酸素消費量, 放出炭酸ガス量は低下し赤血球呼吸は抑制される.

（5）片㑡副腎剔出により赤血球呼吸は著変を来さないが雨側剔出により低下を示す.

(6) Testosterone propionate 少量投与により雄性群に於ては赤血球酸素消費量の增加をみるが雌性群に 於ては著明な変化を来さない.

（7）雄性性腺剔拙により赤血球呼吸は長時日後低下を来す.

（8）Estradiol benzoate 少量投与により赤血球呼吸は抑制されるが殊に雄性群に於ては著明な抑制を示 可.

（9）雌性性腺剔出により赤出球呼吸は直接的には著明な影響を蒙らない. 
(10) 赤血球呼吸唦状赤血球数の増減により推測される成熟赤血球の幻若化と密接な相関を有し内分泌腺 の骨髄造血機能に対する賦活及び抑制を介する影響を認妨るが，それと其に内分泌腺機能は成熟赤血球の呼 吸機能に直接影響を及仿すむのと考えられる。

擱筆に当り恩師故舘石教授立びに親しく御指導，御校閲を賜うつた吉田助教授，佐藤講師に深甚の謝意を 表す. 猶本研究は文部省科学研究費に負う所大であり記して謝意を表する。

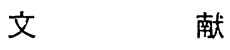

1) Pfüger : Pflüger Arch. physiol. 10, 179 (1875). $\quad$ 2) Morawitz : Arch. exper. Patb. Pharmak., Leipzig. 60, 298 (1909). $\quad 3)$ Warburg : Hoppe-Seylersz., 69, 452, 456 (1910). $\quad 4)$ 伊丹 : Arch. exper. Path. Pharmak., Leipzig, 62,104 (1910). $\quad$ 5) Harrop : Arch. Int. Med., Chicago, 23, 745 (1919). 6) Deneke : z. exper. med., Berlin, 36, 179 (1923). 7) 山本 : 熊本医会誌, 11, 875 (昭和10年). 8) 山本 : 熊本医会誌，12，829，855 (昭和11年). 9) Fries : Biochem. z., Berlin, 35, 368 (1911). 10) 東: 朝鮮医会誌，21，1422（昭和 6 年).

11) Damble : z. exper. med., Berlin, 86, 595 (1933). 12) Bornstein u. Ascher : z. exper. med.,Berlin, 52, 607 (1926).

Batteli u. Stern : Erg. Physiol., 12, 96 (1912).

15）大橋：福岡医誌，41，202，355(昭和25年).

17) 山本：実地医家，12，354 (昭和 9 年).

Bartlett, G.R. \& Marlow, A.A. : J. Lab.Clin. Med. 42, 178 (1953)

\& plasma protein, p. 211 (1953).

21) Dajani, R.M. $\&$

14) Lövgren : Hoppe-Seylers z.,161, 219 (1925).

16) 石関 : 京府医大誌，36，643(炤和17年)。

18) Hattingberg : Z. Biol., 95, 44, 55 (1934).

20) Denstedt, O·F. : inBlood cells 22) Harrop, Barron \& Guzman : J. exper. med., N.Y., 48, 207 (1928).

Naturw., 18, 566 (1930).

24) Zeile u. Euler : Hoppe-Seylers z., 195, 347 (1930).

Deutsch u. Wagenfeld : Dtsch. Arch. klin. Med., 171, 73 (1931).

26）角本 : 京府医大誌，8，299 (昭和 8 年).

27) Horn, Z. u.

Onody, G.

G. : Biochem. Z., Berlin, 226, 286 (1930).

W. : J. gen. physiol., 14, 1 (1930).

29) 後藤: 京府医大誌，54，482 (昭和28年).

28) Payling,

: 東京医会誌，43，81 (炤和 4 年).

31) 伊藤：福岡医誌，43，454（昭和27年).

30) 浅川 福阙医誌，46，923 (昭秃30年)。 33) 阿部他：日血誌，20，370 (昭和 32 年).

32) 本松 :

34) 円野 : The

35）山家他：日血誌，19，196（昭和31年)。 36)

Roessingh : Dtsch. Arch. klin. Med., 138, 367 (1922).

37) 吉田：日本蓲床，10，1048（炤和27年）。 38) 宮崎: 京府医大誌，58，90 (昭和30作).

39) 伊藤：京府医大誌，64，193 (昭和33年).

塚本 ; The Tohoku J. of exper. med., 11, 146 (1928). 41) 大平 : The Tohoku J. of exper. med., 7,146 (1926). 42) 川口他 : 京府医大誌, 65, 936 (昭和34年). 43）川口他：京府医大誌，65， 922 (昭和34年). 44) 田坂他：医学と生物等，41，119 (昭利31牛). 45）佐座：日生㻎誌， 19, 796 (昭和32年). 46）藤田：検圧法と其応用（昭和24年）. 47）清水 : 38) 上万引周.

48) 左座 : 医学研究，27，2388 (昭和32年)

49) Magnus-Levy : 60) より引用。

50) Barker :

Physiol. Rev., 31, 205 (1951). 51) 山本清：ホルモン作用と酥䁷 (1957).

52) 山本清 : 生体

の科学 7,340 (1956).

53）山本 清: ホルモンと臨床，4，934 (昭和31年).

54) 松游：內 分泌学の新動向, 永井普占 (1953).

55）森：内分泌及び尖験治䝤，7，153 (1938).

56) Flask

57) より引朋. 57) Evans : Blood, 8, 131 (1953).

58) Evans：日们泌誌，30，385 (昭和29年).

59) Evans : Endocrinol., 55, 808 (1954).

60) Barker \& Klitgaard: Am. J. physiol., 170, 71 (1952).

61) Meyer \& Ranson : Endocrinology, 36, 259 (1945)

62) 吉弘正久:内分泌，1，342 (1954).

63) 山本清 : 日生理䛱, 17, 210 (1955).

64) 桂博澄：队分必，1，73 (1954).

56) Anselmino

et al. : Biochem. Z., 205, 481 (1929).

66) Scott et al. : Am. J. Physiol., 3, 107 (1935).

67) 
Hopping : Proc. soc. exper. Biol. Med., 28, 726 (1931). (1951) よ可引用. 69）飯塚：26）より引用. 71) DuBois : Basal metabolism (1927). 16, 104 (1930).
68) Issekutz et al. : Physiol. Rev., 31, 210 70) Abelin : Hand. d. norm. u. pałh. physiol.,

73) Aebi, H. \& I. Abelin : Biochem. Z., 324, 364 (1953). 72）春日：京都医学会雑誌，2，385 （昭和26年）より引用.

75) Stern \& Altschule : J. Glin. Invest., 15, 563 (1936). : Endocrinology, 29, 596 (1941).

77) Sharpe \& Bisgard: J. Lab.

76) Gordon \& Charipper : Ann. N.Y. Acad. Soc., 48, 615 (1947). 79) Bürger :

\& Glin. Med., 21, 347 (1936).

78) Bomford: Quart. J. Med., 7, 495 (1938).

81) 川島 : J.

Z. exper. Med., 31, 98 (1923).

80) Negelein : Biochem. Z., 158, 121 (1925).

Biochem., 2, 131 (1923).

82) 加納 : 京府医大誌，52，636(昭和28年).

83) Hoffman et al.

: J. Physiol., 107, 251 (1948).

84) Hill : J.Clin. Endocr., 10, 1375 (1950).

85) Tripton, S.R. : Proc. Soc. Exper. Biol. \& Med., 45, 596 (1940). 86) 関口：日内泌誌，33，755(昭和33年).

87) Lipsett, M.N. \& Moore, F.J. : J. Biol. Chem. 192, 743 (1951). 88) Brummel, E. et al. : J. Endocr., 10, 111 (1954). 89) Barron \& Kit : Trans. Assoc. Am. Physicians 65, 293 (1952).

90)

Berman, J. \& Gordon, S.S. : Am. J. Physiol., 173, 184 (1953). $\quad$ 91) Scarpelli, D.G. et al. : Proc. Soc. Exper. Biol. \& Med., 84, 94 (1953). 92) Bergen, J.R. et al. : Am. J. Physiol., 171, 624 (1952).

93) J.M. Crismon \& J. Field : Am. J. Physiol., 130, 231 (1940). $\quad 94)$ 山本清: 日本臨床，15，1273 (昭和32年)。95) 岸田：日内泌誌，32，臨時增刊䒓，52 (昭和32年)。 96 ) 野手 : 新しい内分 泌学，第 2 集，27 (昭和30年)。 97) 野手：内科最近の進歩，第 2 集，589 (昭和31年)。 98) 野手：ホルモンと臨床，6，501（昭和33年）。99）松田：日本臨床，15，1257（昭和32年）より引用。 100) Eisenberg et al. : Proc. Soc. Exper. Biol. Med., 73, 140 (1950). 101) Kochakian et al. : Ann. N.Y. Acad. Sci., 54, 534 (1951). 102) Dirscherl u. Veltin : Biochem. Z., 323, 408 (1952). - 103) Hausschild, J.D. \& C.M. Grossman : Endcrinology, 53, 306 (1953). 104$)$ 51) 亿ょる. 105) 佐拍：日内泌誌，33，612 (昭和32年). 106) Gonzales et al. : Am. J., Physiol., 149, 502 (1947). 107) Cori, C.F. \& Cori, G.T. : J. Biol. Chem., 74, 473 (1927). 108) Lewis Am. J. Physiol., 164, 617 (1951). 109) 丸本他：日内泌詺，30，185 (1954). 110）镇目：日本臨床，13，897 (1955). 111) 松本他：日内泌誌，30，490 (1954). 112) Roemmelt et al. : Am. J. Physiol., 159, 124 (1949). 113) Lewis, L. A. : Endocrinology, 28, 821 (1941). 114) Whire \& Dougherty : Endocrinology, 36, 16 (1945). 115) Van Dyke, et al. : Acta haematol., 11, 203 (1954). Eiesenberg et al. : Endocrinology, 45, 113 (1949).

117) 川口：京府医大誌，66，1 (昭和34年).

118) Eisenberg et al. : Science, 109, 337 (1949).

119) Barron \& Huggins: J. Urol., 51, 630 (1944).

120) Hayano, M. et al. : Endocrinology, 46, 387 (1950). 121) Dirscherl \& Hauptman : Biochem. Z., 320, 199 (1950). 122) Kochakian, C.D. : Proc. Soc. Exper. Biol. Med., 77, 666 (1951). Ellinger : Hoppe-Seylersz., 119, 11 (1922). 124) Finkelstein, G. et al. : Endocrinology, 35, 267 (1944). 125) Bowman, B.J. et al. : Proc. Soc. Exper. Biol. Med., 87, 136 (1954). 126) Kochakian, C.D. et al. : Am. J. Physiol.: 160, 62 (1950). 127) 51) による. 128) Blacher, J. : Physiol. Rev., 32, 449 (1952). 129) Taber, E. et al.: Am. J. Physiol., 138, 479 (1942). 130) Steinglass, P. et al. : Physiol. Rev., 32, 449 (1952) よ可引用. 131) Mc Cullagh, E.P. \& T.R. Johnes : J.A.M.A., 118, 1003 (1942). 132) Kerly, M. : Biochem. J., 34, 814 (1940). Carroll, W.R. : Proc. Soc. Exper. Biol. Med., 49, 50 (1942).

134) Villee, C.A. \& D.D. Hagerman : J. Biol. Chem., 205, 873 (1953). 135）51）による. 136) Arnold, O. et al. : Arch. exper. Path. \& Pharmak., 186, 1 (1937). 137) Castrodale D. : Endocrinology, 29, 363 (1941). 138) Crafts : Endocrinology, 29, 606 (1941) 